UNIVERSIDADE DE SÃO PAULO

FACULDADE DE FILCSOFIA, CIENCIAS E LETRAS

\author{
BOLETIM CIII
}

\title{
CONTRIBUIÇÃO À GEOLOGIA DOS DERRAMES BASÁLTICOS DO SUL DO BRASIL
}

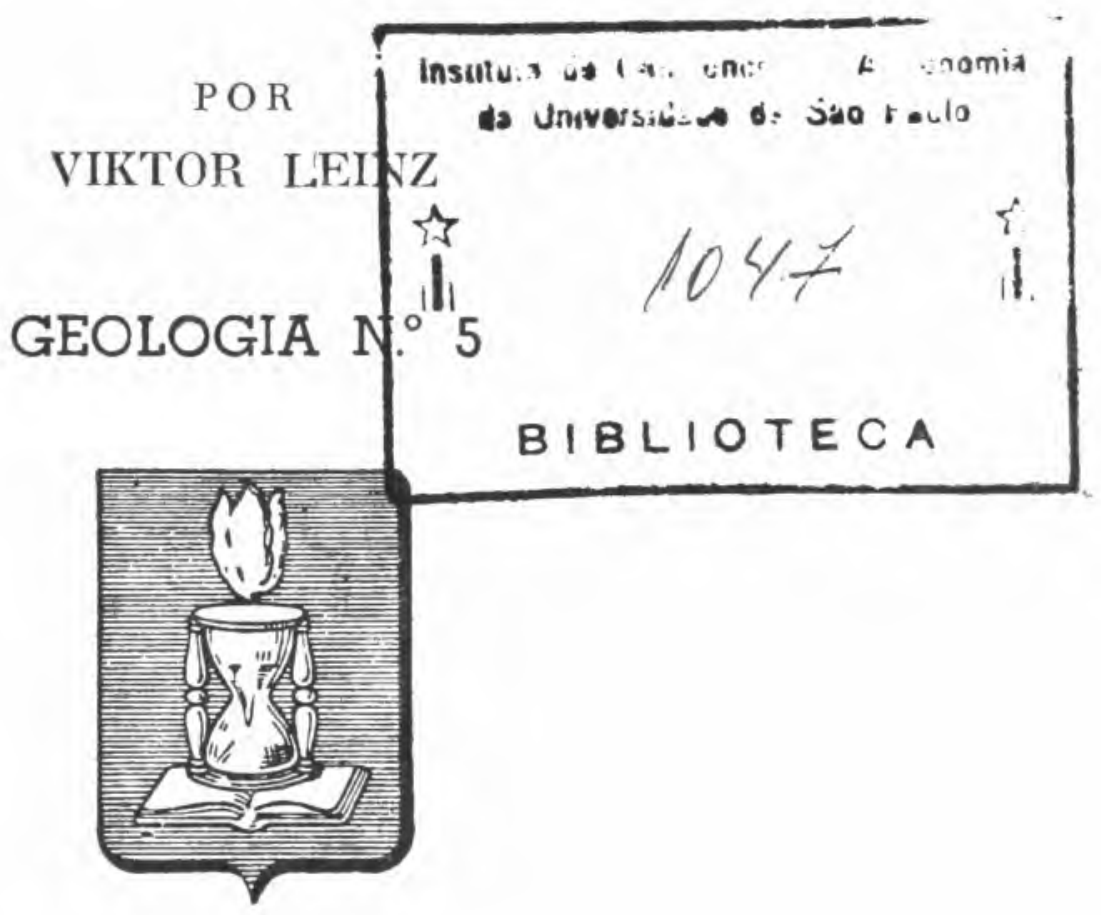

\. kaUlo $\perp_{\text {Brasil }}$

1949 


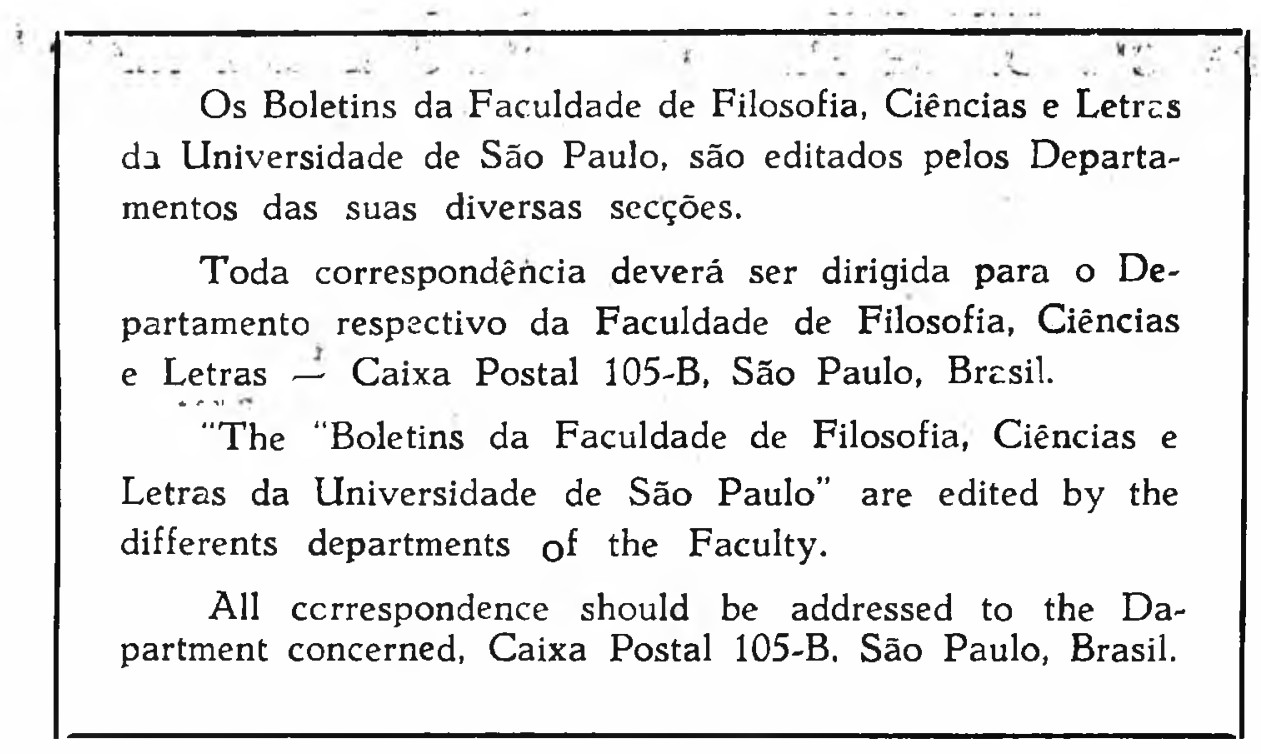

\title{
UNIVERSIDADE DE SAO PAULO
}

\author{
Reitor: \\ Prof, Dr. Miguel Peale
}

Diretor da Faculdade de Filosofia, Ciências e Letras:

Prof. Dr. Astrogildo Rodrigues de Mello

\section{Iepartamento de Geologia e Paleontologia \\ Diretor:}

Prof. Viktor Leinz, Ph. D.

Assistentes:

Josué Camargo Mendes, D. Sc.

Ruy Ozorio de Freitas, D. Sc.

Setembrino Petri, D. Sc. 
A. INTRODUCẼO

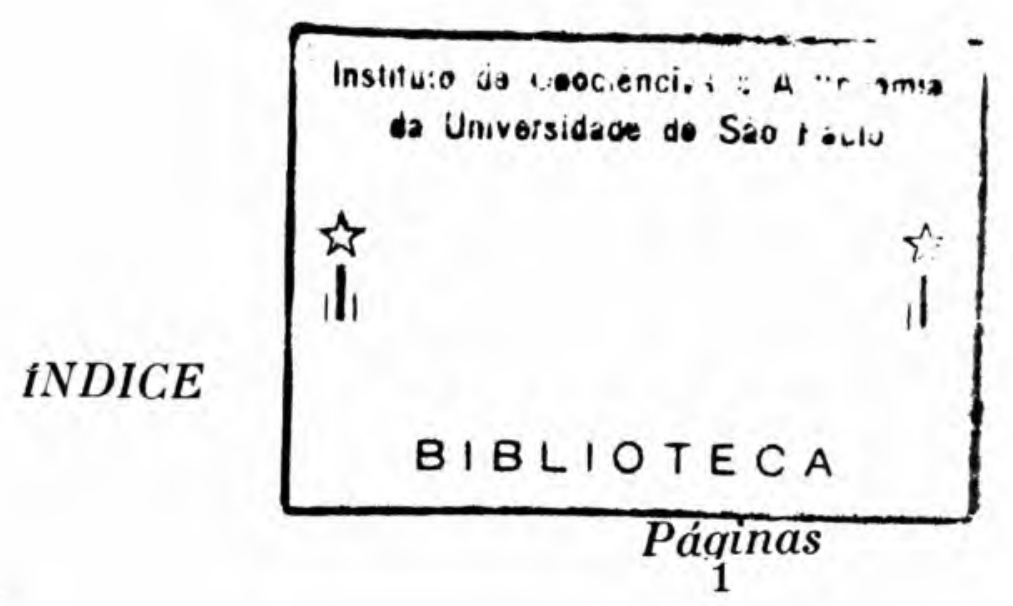

B. VULCANISMO *

I, EFUSIVAS

1. Área ocupada . . 5

2. Espessura global dos derrames $\quad 7$

3. Número dos derrames e suas possanças particulares $\quad . . \quad$. . $\quad 10$

4. Direção das corridas de lava 15

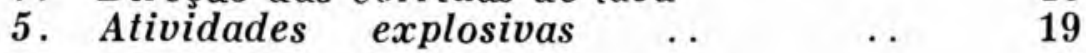

II INTRUSIVAS - DIQUES E SILLS 20

III. PETROLOGIA DAS EFUSIVAS 24

1. Texturas e variações petrográficas .... . 24

2. Variações petrográficas no perfil Três Forquilhas-Tainhas (R. G. S.) 26

3. Composição química 28

4. Mudanças provocadas pelo contacto das $\begin{array}{ll}\text { rochas efusivas com as preexistentes } & 30\end{array}$

C TECTÔNICA

I. MOVIMENTOS ANTERIORES E SIMULTÂNEOS AO VULCANISMO 35

1. Posição do embasamento das efusivas 35

2. Direção e inclinação dos sedimentos pré-efusivos $\quad$.. . $\quad 37$

3. Falhas, zonas de milonitização e diaclases 38 .

4 A linha tectônica Torres-Posadas 41

5. A linha tectônica S. Gabriel-Sta. Maria 44

II. MOVIMENTOS POST-VULCÂNICOS 45

1. Movimentos isostáticos 45

2. Formação de escarpas 47

3. Drenagem fluvial .. 48

D. ASCENSÃO DO MAGMA BASÁLTICO

E. RESUMO _.

F BIBLIOGRAFIA 59 



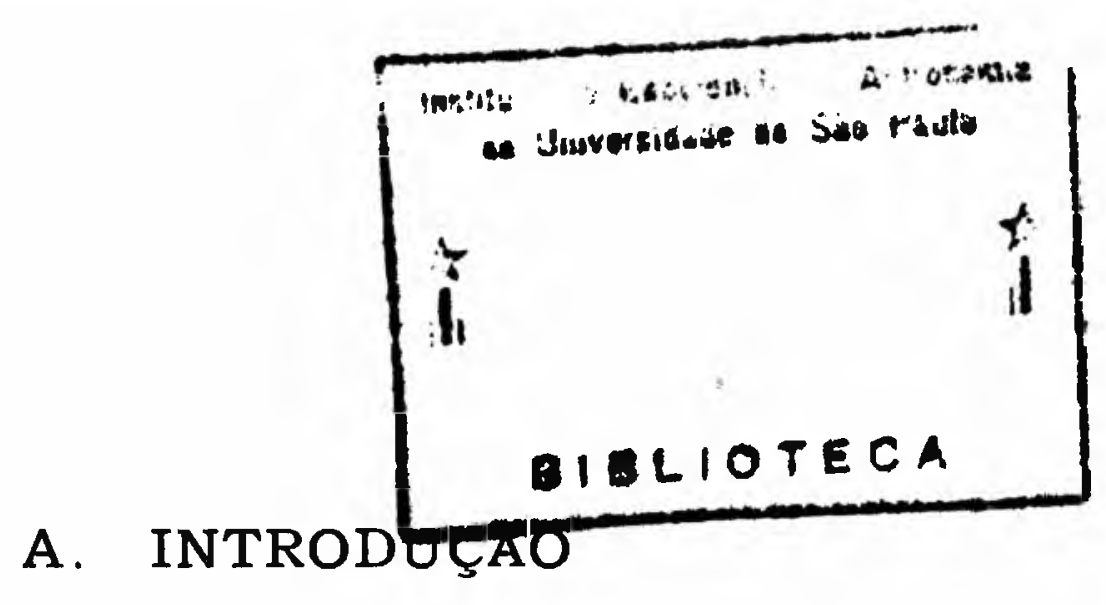

Durante a era mesozóica, entre o eo-mesozóico e o eo-cretáceo, no hemisfério sul, o antigo continente Gondwana sofreu atividades vulcânicas muito intensas. A quantidade de produtos vulcânicos provenientes destas atividades não tem encontrado similar em toda a história da Terra. As áreas atingidas na Índia, África do Sul e América do Sul por esse vulcanismo ainda hoje representam extensões globais de mais de 2 milhões de quilômetros quadrados e o volume de lava produzido foi imenso, alcançando valores que se aproximam de 1 milhão de quilômetros cúbicos. Não existe hoje qualquer exemplo vulcanológico que permita o estabelecimento de uma analogia. Como todos os fenômenos, atuais e do passado próximo, são incomparàvelmente inferiores na sua magnitude, usaremos, com certas ressalvas, o "princípio do atualismo" na interpretação genética.

As causas profundas desse vulcanismo só poderiam ser ventiladas depois da análise criteriosa do fenômeno.

Uma área considerável do sul do Brasil e dos países limítrofes constitui-se de rochas basálticas oriundas desse vulcanismo. Poucos são, entretanto, os conhecimentos que possuimos dele. No presente trabalho nos propomos analisar as atividades vulcanológicas e suas consequências tectônicas. Trataremos, minuciosamente, as áreas dos Estados do Rio Grande do Sul e Santa Catarina. Houve aqui atividades da maior intensidade e, por outro lado, os grandes derrames não foram recobertos por sedimentos posteriores - como acontece na área mais setentrional, nos Estados do $\mathrm{Pa}$ raná, São Paulo e Mato Grosso. Além disso, naqueles dois Estados sulinos os afloramentos permitem observações em duas direções perpendiculares, $\mathrm{N}-\mathrm{S}$ e E-W

\section{HISTORICO DAS PESQUISAS}

Área tão vasta, ocupada pelas rochas basálticas, chamou naturalmente a atenção de todos os estudiosos da geologia do sul do Brasil. Poucos, porém, forneceram descrições pormenorizadas. White (48), em 1908, dá uma descrição rápida de Santa Catarina, acompanhada de estudos petrográficos das amostras colhidas por Merill. Woodworth (49), em 1912, também fornece observações sobre o Estado de Santa Catarina. Em 1932, Baker (3) publicou um trabalho sobre os derrames basálticos da Bacia do Paraná. 


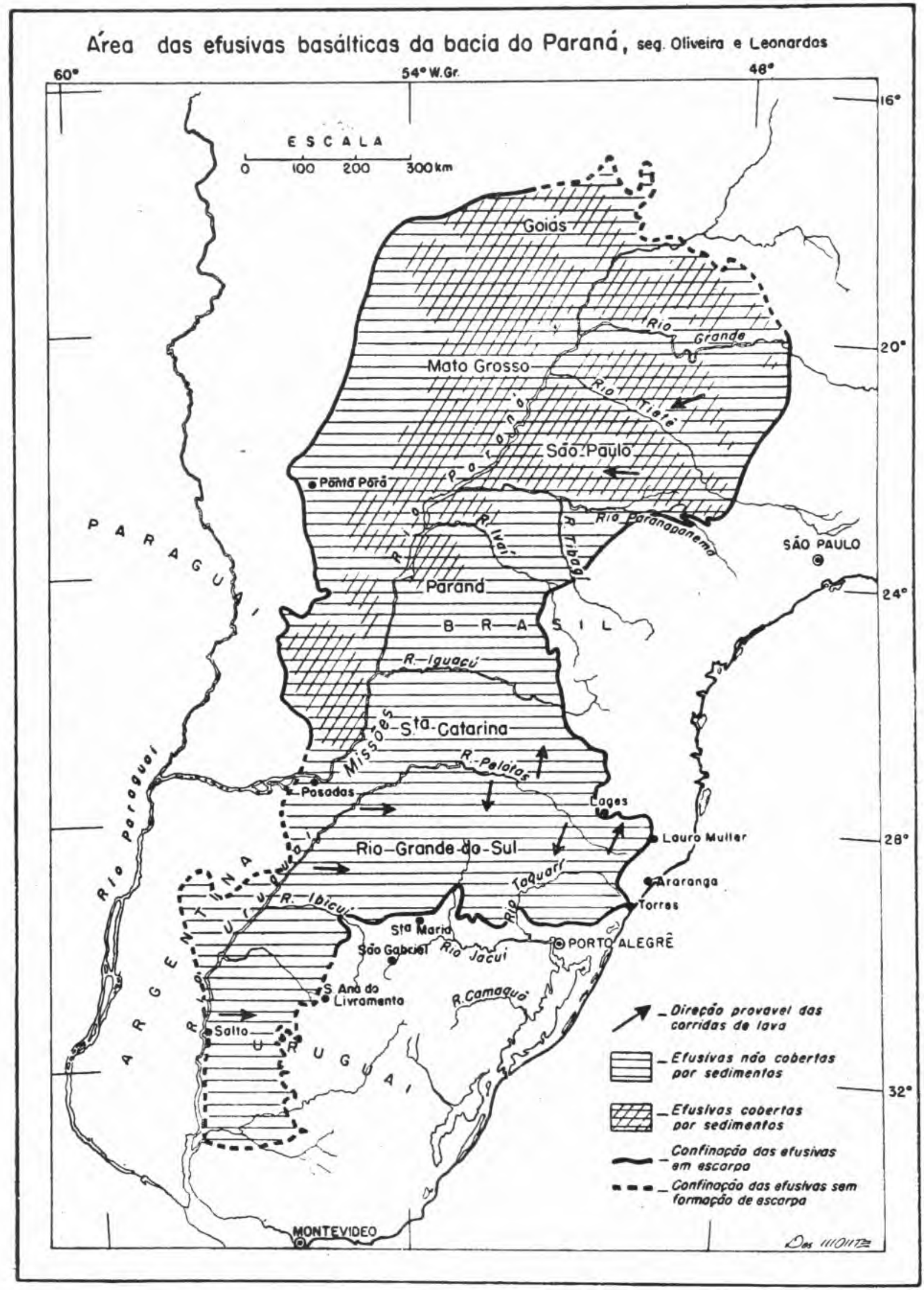

Fig. 1 - Área das efusivas basálticas da bacia do Paraná segundo Oliveira e Leonardos (32) 


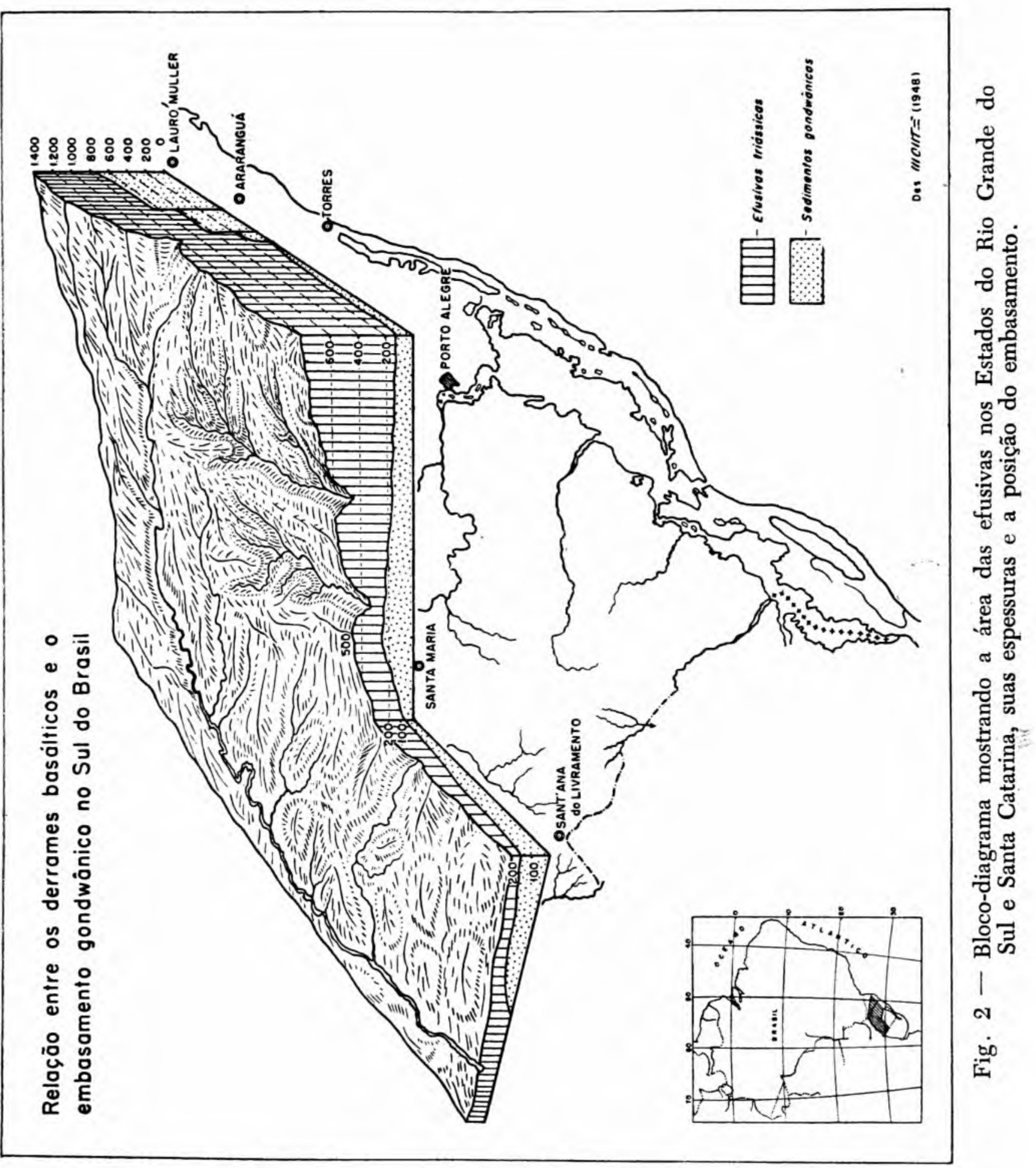


Washburne (46), em 1931, e Moraes Rego (30), em 1932, fornecem alguns pormenores do Estado de São Paulo. Uma descrição petrográfica do conjunto foi fornecida por Walther $(44,45) \mathrm{em}$ 1927 e 1938, e principalmente por Guimarães (12), em 1933.

Outras pesquizas realizadas versam apenas sobre fenômenos locais ou especiais e serão referidas no texto.

As observações do autor datam dos últimos 10 anos. Foram iniciadas principalmente com o caráter de assistência geológica ao plano de aproveitamento hidro-elétrico do Estado do Rio Grande do Sul. Visam, agora ampliadas, proporcionar alguns conhecimentos básicos dos processos vulcanológicos e tectônicos, principalmente na região do planalto riograndense e sulcatarinense.

$$
\text { * * * }
$$

Os derrames basálticos, ocupam quase toda a bacia do Paraná aflorando em boa parte na sua superfície atual. São por isto o membro mais visível das formações "gondwânicas" meridionais. Normalmente as efusivas "transgridem" sobre sedimentos arenosos do Botucatú. Numerosos diques cortam sedimentos e rochas cristalinas em regiões afastadas dos derrames, enquanto que as manifestações intrusivas dos basaltos, sob a forma de sills, registram-se a apenas poucos quilômetros dos afloramentos dos derrames.

Na fisiografia de toda a bacia do Paraná os derrames basálticos desempenham papel predominante. Muito acentuados, tornam-se êles importantíssimos nos seus limites orientais, onde se destacam morfològicamente, constituindo as escarpas abruptas da "Serra Geral" Estas escarpas alcançam normalmente cêrca-de 800-900 metros. Atingem porém, em Santa Catarina, altitudes de 1.600 até quase 2.000 metros, caindo novamente para o sul.

A importância fisiográfica, morfológica, etc. já foi analisada em numerosos trabalhos. Lembramos aqui apenas Baker (3), Washburne (46), Oppenheim (34) e Oliveira e Leonardos (32)

\section{IDADE DA ATIVIDADE VULCÂNICA}

Admite-se, em geral, a título precário, idade rética para as atividades vulcânicas, dada a insegurança da idade dos sedimentos da capa e da lapa das efusivas. Sabemos que as efusivas são posteriores ao arenito Botucatú. Mas este sedimento, possuindo apenas vestígios orgânicos não diagnosticáveis, repousa em parte em discordância erosiva, segundo Gordon (11), sôbre as camadas de Santa Maria. Nestas camadas foi encontrada uma fauna de Rhynchosauridae, Cynodontia e Pseudosuchia. O primeiro fóssil foi achado em 1902 e descrito por A. S. Woodworth como Scaphonyx fischeri. Pelos trabalhos de v. Huene (17) e de Price (37) fixa-se a idade triássica superior para as camadas de Santa Maria, comparáveis ao 
Molteno da série Stromberg da África do Sul. Outros sedimentos fossiliferos denominados formação Baurú, são posteriores às atividades vulcânicas. Nesta formação foram encontrados restos de titanosáurios descritos entre outros por v. Huene (16) Este autor julga haver identidade fossilífera com os sedimentos da Patagônia, de idade Senoniana. Assim, as atividades vulcânicas e também os arenitos de Botucatú ficam limitados entre o Triássico Superior e Cretáceo Superior. Autores que estudaram, mais recentemente, a estratigrafia da série São Bento, Gordon, (11) e Maack (29), acham provável que a sedimentação do arenito Botucatú tivesse perdurado no Jurássico e por isso situam as atividades vulcânicas, naturalmente também a título provisório, no Jurássico.

Incerteza semelhante existe na determinação cronológica dos doleritos sul-africanos do Karroo. Du Toit (9) admite para eles a idade jurássica como a mais provável. A cronologia das efusivas do Deccan (India) já é mais segura. Segundo Wadia (43) a sua extrusão não pode ser mais antiga que o Cretáceo Superior (Daniano) e nem mais moderna que o Eoceno.

\section{B. VULCANISMOS}

\section{EFUSIVAS}

\section{1. ÁREA OCUPADA}

Seja no fim do Triássico (Rético), seja no Jurássico, o sul do Brasil e os países adjacentes foram atingidos por extensa atividade vulcânica produzindo vastos derrames e intrusões sob forma de sill e dique. A bacia do Paraná existente como província geológica sedimentária desde o Devoniano, foi quase totalmente coberta por efusivas basálticas. $O$ embasamento destas efusivas é constituido, em toda essa vasta área, por arenitos triássicos de origem dominantemente eólica. A área hoje ainda ocupada pelas rochas vulcânicas orça por volta de 1 milhão de quilômetros quadrados. Baker (3) estima-a em 800.000 quilômetros quadrados e calcula ainda em 200.000 quilômetros quadrados as atingidas por diques e sills. Oppenheim (34) calcula a superfície em 1,2 milhōes de quilômetros quadrados incluindo aqui, porém, áreas hoje cobertas por sedimentos posteriores, nas quais a existência de rochas basálticas foi verificada apenas por sondagens. Almeida (1) chega a resultados superiores. Este autor admite que cerca de 4 milhões de quilômetros quadrados foram atingidos pela atividade magmática, isto é, além da bacia do Paraná pròpriamente dita, foi atingida a planicie chaco-pampeana até as serras Pampeanas e Precordilheiras. As suas deduções baseiam-se em algumas sondagens existentes, revelando rochas basálticas possivelmente triássicas, porém não pos- 
suimos dados para julgar essa avaliação. Como área mínima ocupada por efusivas podemos seguramente aceitar os valores de Baker (3) e Guimarães (12), isto é, um valor por volta de 800.000 a 1 milhão de quilômetros quadrados. Mais da metade desta área é hoje capeada por sedimentos principalmente de idade cretácea. A existência de efusivas por baixo dessa cobertura é à miude demonstrada pela erosão.

A área originalmente ocupada pelas efusivas foi sem dúvida maior, mas de difícil estimação, porquanto as regiões atingidas por manifestações periféricas do vulcanismo, sob forma de dique, alcançam vulto considerável. Contudo, temos ainda dúvida sobre a filiação de todos os diques de diabásio à fase vulcânica triássico-jurássica.

Todavia, podemos afirmar, com segurança, que o vulcanismo que atingiu a bacia do Paraná foi dos maiores, abrangendo a: mais vasta área conhecida até hoje na história geológica.

A título de comparação ùnicamente, acrescentaremos alguns dados mụito breves sobre outras regiōes gondwânicas afetatadas por fenômenos vulcânicos em escala similar.

\section{África do Sul}

Apesar da intensa atividade vulcânica, provàvelmente de idade jurássica, não chegou a se formar um derrame basáltico contínuo, semelhante ao da bacia do Paraná ou Deccan. Mas são inúmeros os focos e derrames nas várias regiōes que constituem, em conjunto, também áreas respeitáveis. Só os "Doleritos do Karroo", no Basutoland, cobrem uma área de-cerca-de 80.000 quilômetros quadrados. Krenkel (21) estima a área total atingida pelo vulcanismo jurássico entre $300-400$ mil quilômetros quadrados. Mas é interessante o fato de, na Africa do Sul, serem as rochas intrusivas muito frequentes, como também a ocorrência de certas diferenciações magmáticas muito pronunciadas, ao contrário do que acontece no Brasil.

\section{India}

Grande área foi atingida por "estupenda manifestação de energia vulcânica", segundo Wadia (43), formando o Trapp do Deccan. Sua cronologia também não é muito definida, e, de acordo com Wadia (43), situa-se entre o Cretáceo Superior e o Eoceno.

A área ocupada pelo trapp é de-cêrca-de 650.000 quilômetros quadrados, atingindo as espessuras máximas até 3.000 metros (!) ao longo da costa de Bombay, e decrescendo ràpidamente para $\mathbf{1 5 0}$ metros e $\mathbf{5 0}$ metros nos flancos $\mathbf{N}$ e $\mathbf{E}$ (fig. 3) 


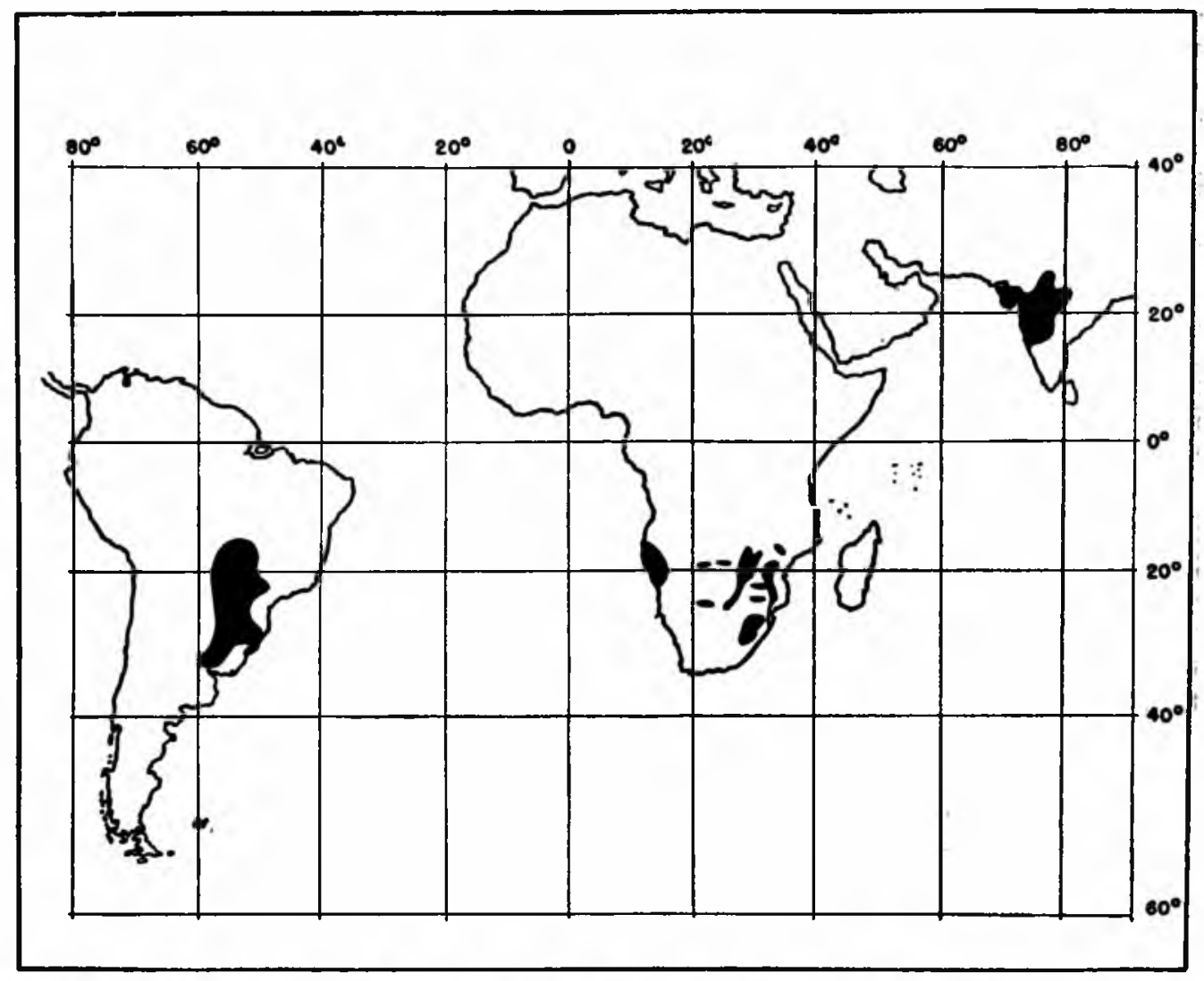

Fig. 3 - Derrames basálticos triássico-cretáceos do antigo continente "Gondwâna"

\section{ESPESSURA GLOBAL DOS DERRAMES NA ORLA ORIENTAL DO BRASIL}

Analisemos as espessuras observadas em vários pontos do sul do Brasil (Tabela $n^{\circ}$ 1)

Diversos autores referiram "espessuras" locais das massas efusivas. No Rio Grande do Sul e Santa Catarina as rochas basálticas formam diretamente a superfície atual. Não sabemos se já . possuiram antigamente uma capa protetora ou se estão expostas aos agentes destrutivos desde a sua formação. Por isso as observações referem-se apenas às espessuras conservadas. Nas áreas mais para o norte os derrames acham-se cobertos por um manto de sedimentos jurássicos(?)-cretáceos.

Nas medições, só podemos tomar, portanto, como ponto de referência certo e inconfundível, a base do derrame, marcada pelo contato com o arenito "Botucatú" Esse mesmo é em parte duvidoso, dada a ocorrência de sills nesse arenito. $O$ topo é determinado pela elevação máxima atual, eliminados os casos onde se deve suspeitar a ocorrência de "falhas" Esse topo pode distar da base, em linha horizontal, apenas poucos ou até várias dezenas de quilômetros (Fig. 4)

Um aumento ou diminuição de espessura devido a falhamento escalonado não foi observado. 
$\mathrm{Na}$ tabela n. 1 fornecemos algumas espessuras observadas, todas naturalmente referentes à orla escarpada. Nota-se nesses dados que a espessura máxima é de-cerca-de 1.000 metros. verificada na região de Torres-Três Forquilhas, R. G. S. Diminuem as espessuras ràpidamente, tanto rumo norte como sul, atingindo valores de pouco excedentes a 100 metros na parte norte (São Paulo) como também no extremo sul (Rio Grande do SulUruguai) interessante observar que a espessura também declina continuamente rumo $\mathrm{W}$; no único perfil observável nesse sentido, no Rio Grande do Sul, cai de 800 metros (Osório) para cerca de 200 metros em Jaguarí.

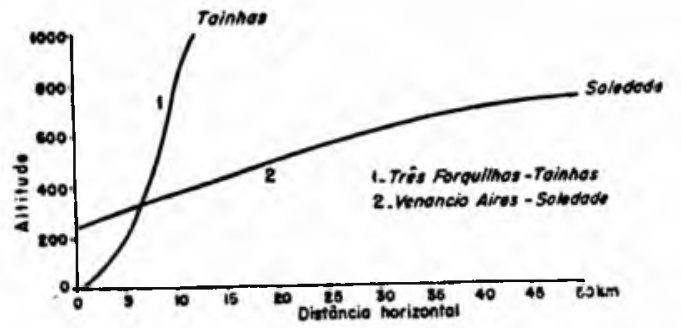

Fig. 4 - Gráfico demonstrativo da variabilidade da exatidão das medidas de espessura dos derrames, em topografia de escarpa

(1) e de declive suave (2)

Em resumo, verifica-se que a espessura máxima situa-se na divisa do Rio Grande do Sul-Santa Catarina, na orla marítima, havendo uma diminuição contínua para o $\mathrm{N}$, para o $\mathrm{S}$, bem como para $\mathrm{W}$

As observações das espessuras do derrame na orla ociden. tal, ou no centro da bacia do Paraná, são pouco numerosas.

Segundo Almeida (1), na escarpa ocidental das efusivas do Estado de Mato Grosso, os derrames medem em conjunto cerca de 350 metros. No centro da bacia do Paraná, Hausen (15) encontrou, em perfurações perto de Posadas (Argentina), e sem atingir o embasamento, 437 metros de espessuras das efusivas. Em outra sondagem a perfuração atingiu 470 metros encontrando um embasamento arenítico. As sondagens na província de Missões foram menos profundas e não atingiram o embasamento. $\mathrm{Na}$ província de Corrientes foram encontradas espessuras para os derrames de, pelo menos, $\mathbf{3 5 0}$ metros, pois aqui, também, não se atingiu o embasamento.

Na sondagem de S. Cristobal, Santa Fé, Argentina, locada a 150 quilômetros a oeste do rio Paraná, foram encontrados cerca de 100 metros de efusivas cobertas por sedimentos mais modernos.

Como ainda não conhecemos as espessuras reais das efusivas do eixo da bacia do Paraná, continua aberto o problema se as espessuras máximas são localizadas nas orlas ou no centro da bacia. E óbvio que perfurações (ou pesquisas geofísicas) no centro do eixo da bacia, visando a determinação das espessuras dos derrames, poderiam trazer dados para o esclarecimento tectônico da bacia e consequente auxílio ao estudo das pesquisas de petróleo na região. 
TABELA N.9 1

\section{Espessura global dos derrames \\ Rio Grande do Sul}

\begin{tabular}{|c|c|c|c|c|}
\hline Localidade & $\begin{array}{l}\text { Base (sobre o } \\
\text { nivel do mar) }\end{array}$ & $\begin{array}{l}\text { Topo (sobre o } \\
\text { nível do mar) }\end{array}$ & Espessura & Autor \\
\hline Três Forquilhas . . & $+25 \mathrm{~m}$ & $\begin{array}{c}1050 \mathrm{~m} \\
\text { (Tainhas) }\end{array}$ & $1025 \mathrm{~m}$ & Leinz \\
\hline Osorio $\ldots \ldots \ldots \ldots$ & $+60 \mathrm{~m}$ & $900 \mathrm{~m}$ & $\$ 00-850 \mathrm{~m}$ & Leinz \\
\hline S. Antonio $\ldots \ldots \ldots$ & $+75 \mathrm{~m}$ & $900 \mathrm{~m}$ & $800 \mathrm{~m}$ & Leinz \\
\hline Sander $\quad \ldots \ldots \ldots \ldots$ & $160 \mathrm{~m}$ & $\begin{array}{c}830 \mathrm{~m} \\
\text { (Canela) }\end{array}$ & $700 \mathrm{~m}$ & Leinz \\
\hline Feliz $\quad \ldots \ldots \ldots \ldots$ & $180 \mathrm{~m}$ & $\begin{array}{r}750 \mathrm{~m} \\
\text { (Caxias) }\end{array}$ & $570 \mathrm{~m}$ & Leinz \\
\hline Venancio Aires .... & $240 \mathrm{n}$ & $\begin{array}{c}720 \mathrm{~m} \\
\text { Guaporé) }\end{array}$ & $480 \mathrm{~m}$ & Leinz \\
\hline Candelaria $\quad \ldots \ldots \ldots$ & $260 \mathrm{~m}$ & $\begin{array}{c}720 \mathrm{~m} \\
\text { (Soledade) }\end{array}$ & $460 \mathrm{~m}$ & Leinz \\
\hline Sta. Maria ........ & $270 \mathrm{~m}$ & $\begin{array}{c}570 \mathrm{~m} \\
\text { (Pinhal) }\end{array}$ & $\pm 300 \mathrm{~m}$ & v. Huene (17) \\
\hline Jaguarí $\quad \ldots \ldots \ldots \ldots$ & $\pm 120 \mathrm{~m}$ & $+350 \mathrm{~m}$ & $200 \mathrm{~m}$ & Leinz \\
\hline Livramento $\ldots \ldots \ldots$ & $250 \mathrm{~m}$ & & $10 \mathrm{~m}$ & Leinz \\
\hline
\end{tabular}

Santa Catarina

\begin{tabular}{|c|c|c|c|c|}
\hline Araranguá-Pedra .. & $350 \mathrm{~m}$ & $1200 \mathrm{~m}$ & $850 \mathrm{~m}$ & Leinz \\
\hline Cresciuma $\quad \ldots \ldots \ldots$ & $650 \mathrm{~m}$ & $1300 \mathrm{~m}$ & $650 \mathrm{~m}$ & Leinz \\
\hline Estrada Nova .... & $748 \mathrm{~m}$ & (S. $\stackrel{ \pm 1360 \mathrm{~m}}{\text { Joaquim) }}$ & $600 \mathrm{~m}$ & $\begin{array}{c}\text { White (48) } \\
\text { Rocha (39) } \\
\text { Leinz }\end{array}$ \\
\hline Lages (Oeste) ..... & $980 \mathrm{~m}$ & $1200 \mathrm{~m}$ & $200 \mathrm{~m}$ & Leinz \\
\hline
\end{tabular}

Paraná

\begin{tabular}{l|c|c|c|c}
\hline Porto União $\ldots . . .$. & $850 \mathrm{~m}$ & $1200 \mathrm{~m}$ & $350 \mathrm{~m}$ & Leinz \\
\hline Guarapuava $\ldots \ldots \ldots$ & - & - & $250 \mathrm{~m}$ & $\begin{array}{c}\text { E. Oliveira } \\
(33)\end{array}$ \\
\hline Serra Esperança ... & $\mathbf{7 0 0 m}$ & $1250 \mathrm{~m}$ & $250 \mathrm{~m} \quad \begin{array}{c}\text { Pl. de Lima } \\
\text { (inf. verìal) }\end{array}$ \\
\hline
\end{tabular}

\section{S. Paulo}

\begin{tabular}{ll|c|c|c|c}
\hline S. Pedro $\ldots \ldots \ldots \ldots$ & $720 \mathrm{~m}$ & $880 \mathrm{~m}$ & $150 \mathrm{~m}$ & Leinz \\
\hline Botucatu' $\ldots \ldots \ldots \ldots$ & $800 \mathrm{~m}$ & $880 \mathrm{~m}$ & $\pm 80 \mathrm{~m}$ & Leinz \\
\hline
\end{tabular}


Para poder estimar a espessura média do total dos derrames, com o fim de poder avaliar a massa magmática fornecida pela atividade vulcânica, dispomos, portanto, de poucos dados.

O maior número de observações foi feito na orla oriental onde calculamos a espessura média em 350 metros. No bordo ocidental, no lado noroeste, Almeida (1) encontrou valores semelhantes. Do centro da bacia sabemos apenas, pelas poucas sondagens acima citadas, que as espessuras não devem ser inferiores a 350 metros no sul do país. Assim podemos calcular, com muita reserva, que a massa das efusivas ainda conservada atinge no mínimo cerca de 350.000 quilômetros cúbicos. Baker (3) calculou a massa em 260.000 quilômetros cúbicos. A massa total consolidada em forma de diques e sills não foi considerada. Acreditamos que o volume destas formas intrusivas, pelo menos no lado oriental, não altera substancialmente o volume total. Sòmente se a hipótese de Almeida (1), da existência de uma área muito mais vasta atingida pelo vulcanismo for confirmada, então o volume total aumentará muito.

\section{NÚMERO DOS DERRAMES E SUAS POSSANÇAS PARTICULARES}

Vários são os elementos que permitem deduzir o número de corridas de lava. As intercalações de sedimentos clásticos depositados entre os basaltos são o indício mais seguro de hiato da efusão. São sedimentos semelhantes ao arenito Botucatú, também de côr avermelhada e possuem, frequentemente, estratificação cruzada. - No sul do Brasil (Rio Grande do Sul-Sta. Catarina) encontram-se intercalações pràticamente só a oeste da linha Lages-Sta. Maria, enquanto que a orla oriental é pràticamente isenta destas intercalações. A sedimentação eólica proveniente do $\mathrm{W}$, de acordo com as poucas verificações relativas à estratificação cruzada, já não atingiu a faixa oriental. Em afloramentos pequenos e principalmente perto da base dos derrames pode tornar-se difícil a distinção entre a sedimentação infra-efusiva e a ocorrência de blocos de arenito Botucatú arrastados do embasamento ou atravessados por sills, como acontece na subida Sander-Canela ( $R$. G. S.). Os efeitos de metamorfismos bilaterais, característicos para arenitos preexistentes, são difíceis de serem observados. A espessura das camadas formadas nos intervalos das atividades magmáticas varia de poucos centímetros a duas dezenas de metros.

O melhor afloramento para a observação das intercalações arenosas é o de Sta. Maria (R. G. S.) Já Huene e Stahlecker (17) descreveram a ocorrência. Encontram-se aí 7 intercalações de bancos de arenitos variando entre 30 centímetros e 7 metros. A espessura das corridas de lava aqui é pequena na base, tendo cerca de 6 metros apenas. A segunda é de 8 metros, a terceira de 
12 metros, a quarta de 14 metros, a quinta de 30 metros, a sexta de 25 metros, a sétima de 15 metros, ao passo que a última é decerca-de 110 metros. Encontra-se, assim, um mínimo de 8 derrames sucєssivos. E naturalmente incerto se a ausência de intercalações no último derrame significa realmente um derrame único.

$\mathrm{Na}$ região de Ijuí e de São Luiz (R. G. S. ) perto da vila de Guaramano encontram-se 3 intercalações areníticas de-cerca-de 3 metros de espessura separando os derrames com 20 metros de espessura cada.

Almeida (1) descreve na Serra de Macarajú (Mato Grosso) quatro camadas de arenito intra-efusivo, com uma espessura normal de 1 a 2 metros podendo atingir até 12 metros. As espessuras particulares dos derrames em Mato Grosso são variáveis. Aquele autor encontrou, com maior frequência, espessuras de cerca-de 40 metros. Descreve, ainda, derrames de até 150 metros de possança.

Todos os dados sobre a espessura do derrame existentes na literatura referem-se à determinação por meio de intercalações de arenitos, chegando-se, assim, às vezes, a espessuras de 200 metros para um único derrame, fato jamais observado por nós. Por isto não aproveitámos esses poucos valores extremos na construção do gráfico sobre a frequência das espessuras. Raras vezes os afloramentos permitem a verificação de vários estratos intercalados, e nas deduções sobre a espessura e o número de derrames é preciso basear-se em fenômenos indiretos, tais como: a) variações das texturas de rochas: amigdalóide-vesicular, vítrea, micro e macrogranular e b) variações das diaclases de contração.

Na subida da serra de Três Forquilhas-Tainhas (R.G.S.) observa-se, repetidas vezes, a seguinte alternância textural dos basaltos, de baixo para cima: uma zona de basalto vítreo, brilho de pixe, preto, com espessuras que variam de 5 a 10 metros. Esta faixa vítrea passa gradativamente para um basalto microcristalino, rico em diaclases horizontais, aparentando um sedimento (Fot. 3). Segue-se um basalto micro a macrocristalino, com diaclases predominantemente verticais. No lugar citado, esta zona possui até $\mathbf{4 0}$ metros de possança. Mais para o topo aparecem, novamente, diaclases horizontais seguidas por uma zona de 5-10 metros, rica em amígdalas vasias ou preenchidas por zeolitas, etc. Estas amígdalas são normalmente elíticas, com o eixo menor no sentido vertical.

Estas variações parecem-nos características para uma corrida de lava. A zona vítrea representa a soleira (*) do derrame com resfriamento rápido devido ao contacto com o embasamento ao passo que a faixa "melafírica" é a zona de enriquecimento de ga-

(*) O termo soleira foi introduzido na literatura geológica por Euzébio de Oliveira para traduzir a palavra inglêsa sill. Como êste termo não foi usado, subsequentemente, aproveitamo-lo para indicar a parte basal de um derrame. 
ses sob alta pressão conjugada com resfriamento rápido graças ao contacto com a atmosfera. As diaclases de contração são horizontais perto dos contactos e verticais no centro dos derrames onde o resfriamento é lento. Quando a espessura da corrida é apenas de uns 10 metros a zona central micro a macrocristalina poderá faltar.

A formação de diaclases horizontais é normalmente explicada pelo efeito da contração magmática. Mas Philipp (36) explica as diaclases horizontais também pelo efeito de corridas laminares de lava.

Usando tal critério foi possível discriminar nas escarpas contínuas e frescas, mas acessíveis, de Lauro Müller-S. Joaquim (S.C.) e Três Forquilhas-Tainhas (R.G.S.) vários derrames sucessivos, todos sem intercalações areníticas. Para o caso de Lauro Müller, encontrámos 6 sucessões completas e 3 com falta da zona vítrea. Chegamos portanto a 9 corridas de lava sucessivas variando as espessuras entre 50 e 110 metros.

Na subida de Três Forquilhas para Tainhas, onde uma estrada nova fornece ótimos afloramentos, observa-se ainda maior número de derrames (Fig. 6) O característico principal desse perfil

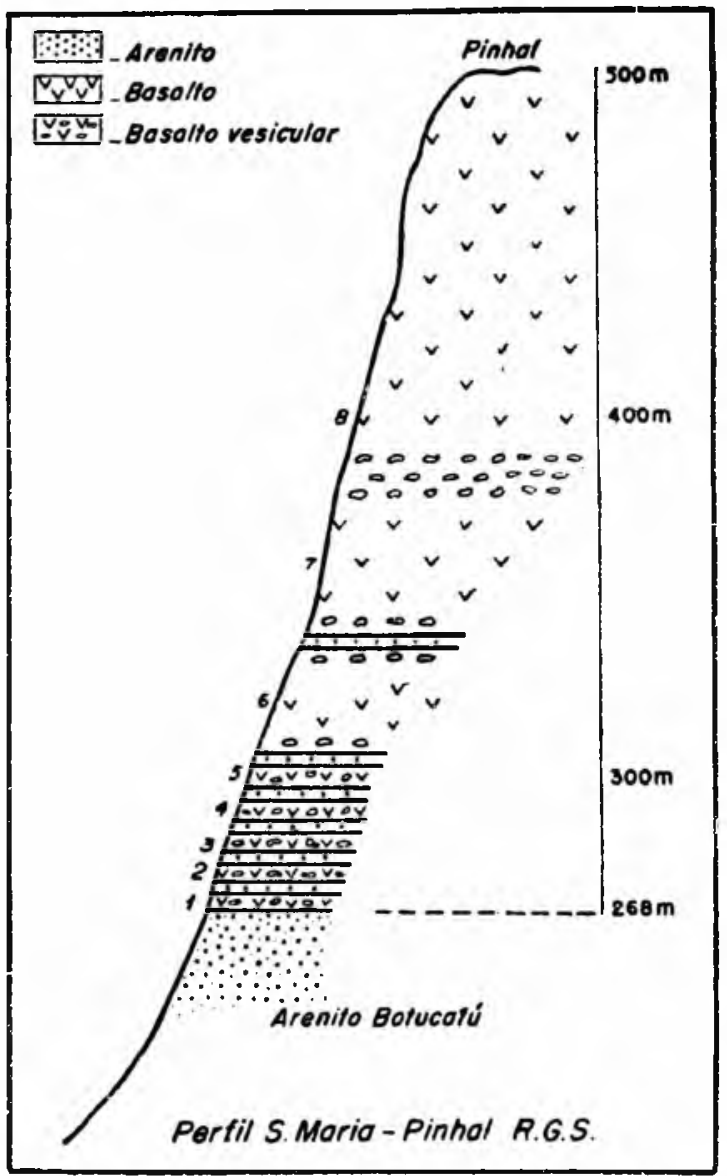

Fig. 5 - Perfil Sta. Maria-Pinhal (Rio Grande do Sul) mostrando 8 derrames sucessivos.

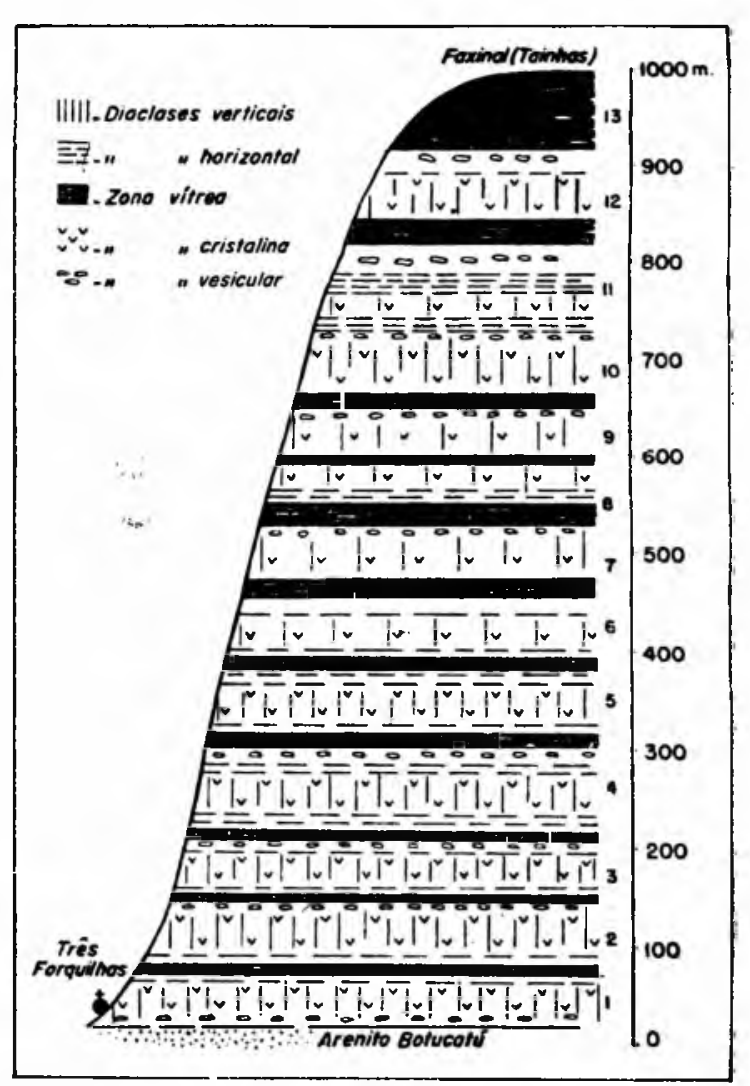

Fig. 6 - Perfil Três Forquilhas-Faxinal (Tainhas), Rio Grande do Sul, mostrando 13 derrames sucessivos. 
é a pequena espessura da zona porosa, atingindo apenas 2-3 metros, e a grande possança da faixa vítrea ou hialo-basáltica que é normalmente, de 20 metros, mas pode atingir 30 metros de espessura. São bem nítidas as variações das diaclases entre as horizontais e verticais. Somam 13 os derrames aí observados, com espessuras variáveis entre 50 e 130 metros, tendo espessura global de 1.000 metros. A ocorrência das espessas faixas vítreas nesse local pode-se talvez explicar pela maior viscosidade da lava que, principalmente no topo, é muito rica em $\mathrm{SiO}_{2}(65 \%)$, como se vê na tabela $n^{\circ} 3$, ou por extrusão sucessiva e rápida de corridas delgadas de magma, comportando-se o conjunto como um derrame único.

Fig. 7 - Frequência das espessuras dos derrames.

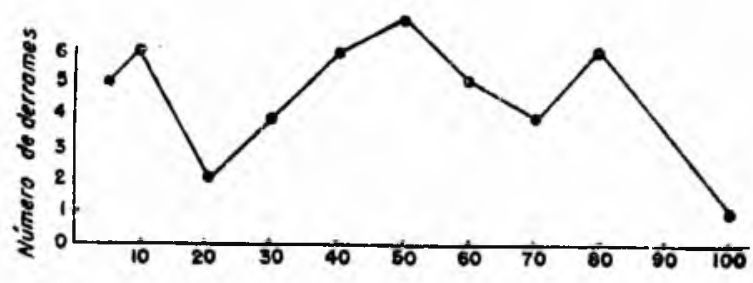

Os dados colhidos permitem construir um gráfico da frequência das espessuras dos derrames. Observa-se na fig. 7 a existência de 3 máximos com espessuras de 10 metros, 50 metros e 80 metros.

As espessuras por volta de 10 metros concordam com as possanças de derrames citadas na literatura. Assim Daly (6) dá como valor médio cerca de 15 metros para os derrames do Deccan (India) e de Oregon (E. U.), enquanto que as corridas de lava da: Islândia variam entre 5 e 10 metros.

Jacobsen (20), estudando efusivas do "plateau" algonquiano, verificou entre 80 espessuras medidas um máximo de 15 metros e outro de 30 metros, registrando em alguns casos espessuras de: 60 metros.

Os "máximos" de 50 e 80 metros achados por nós são muito. superiores aos acima citados.

E' bem possível que estas grandes espessuras sejam na verdade formadas por superposição de mais de um derrame, extravasados sucessivamente e comportando-se na sua textura como uma unidade. Sòmente hiatos maiores na vasão magmática produziram texturas características.

Lembramos, por outro lado, que as espessuras maiores foram registradas principalmente na orla oriental dos derrames, entre Lauro Müller e Osorio, onde tudo indica a proximidade de uma zona de intensa produtividade magmática. As espessuras mencres, de 10 a 20 metros, foram verificadas em regiōes provàvelmente periféricas às zonas de extravasamento magmático. 
$E^{\prime}$ interessante salientar que a erosão e a decomposição seletiva fazem ressaltar frequentemente, na topografia, as unidades de derrame. São conhecidos os beirais abruptos na orla oriental das efusivas, formando escadas de degraus sucessivos (aliás de onde vem o nome sueco "trapp" = escada) No fot. 4 observam-se 5 ou 6 destes degraus.

A faixa de diaclases horizontais e de textura amigdaloide decompõe-se mais intensamente, dada a maior retenção da água de percolação, - são os níveis das fontes e da vegetação, formando

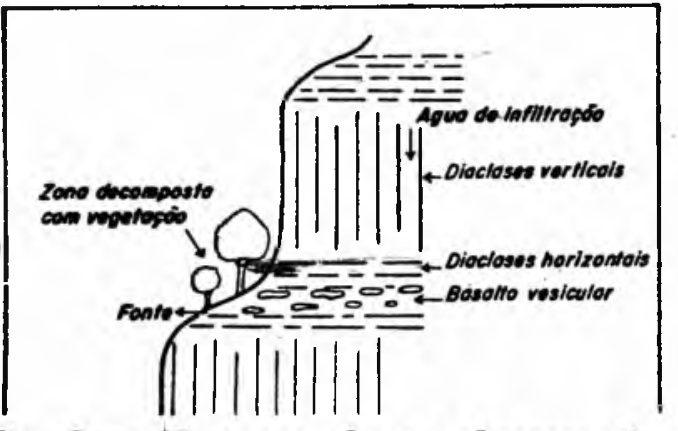

Fig. 8 - Esquema de um derrame formando "escada" morfológica. Voriaçoo de rexfura e estrufura de um derrame basaltico

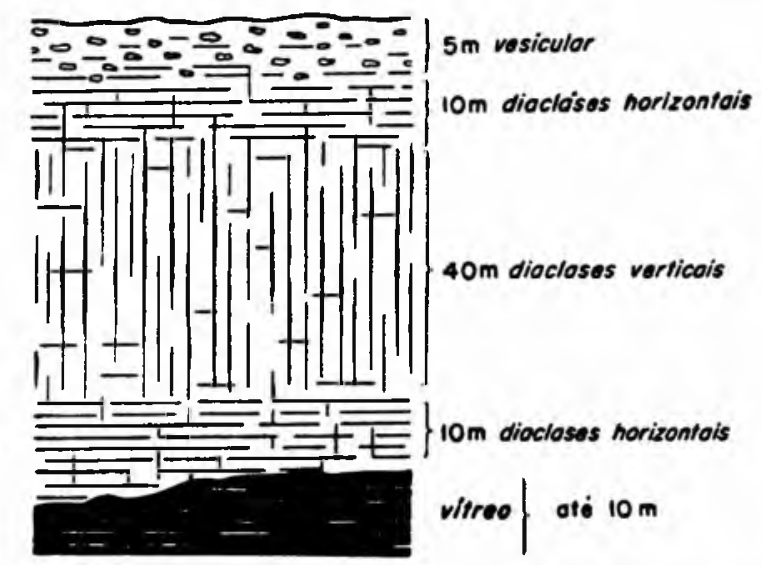

Fig. 9 - Esquema da variação de textura de um derrame basáltico.

assim o piso do degrau. A zona com diaclase vertical já se mostra mais escarpada, justamente por causa das juntas verticais facilitarem a disjunção de blocos segundo planos a prumo, com solapamento por đecomposição mais rápida do piso.

Naturalmente, nem todo derrame forma necessàriamente escadas morfológicas.

A gênese de ressaltos e quedas d'águas nas áreas cobertas pelas efusivas é, em boa parte também, referível à variação em textura e diaclasamento dos derrames. A erosão fluvial trabalhando a zona de diaclases horizontais escava leitos de rios rasos, com pequenos "saltos" escalonados de decímetros de altura, até atingir a faixa das diaclases verticais predominantes. Aqui a erosão penetra ràpidamente em profundidade, dado o desmoronamento dos "prismas" verticais da efusiva, formando um canalão ("canyon") cuja base é geralmente a zona das diaclases horizontais subjacentes.

As fot. 1, 2 mostram, respectivamente, um trecho de pequenos saltos sucessivos na zona das diaclases horizontais, nas cabeceiras do rio Tainhas ( $R$. G. S.), e o canalão que se segue, com 30 metros de profundidade, aberto na zona das diaclases verticais. 


\section{DIREÇÃO DAS CORRIDAS DE LAVA}

\section{a. Superfície da corrida de lava}

Verifica-se como primeiro fato que os derrames se realizaram sobre planos pràticamente horizontais. Chegamos a esta conclusão do modo que passaremos a expôr.

A zona vitrea de um derrame conserva-se, em geral, pràticamente no mesmo nível. Assim podemos observar no Vale Carvalho (Três Forquilhas, R. G.' S.), por nivelamento de precisão, um deslocamento de-cerca-de 15 metros apenas na vertical para uma distância de $\mathbf{5}$ quilômetros, rumo sul-sudoeste. Essa descida de 15 metros em 5, quilômetros foi obtida no mesmo lugar para três diferentes zonas sobrepostas. Apesar dos pontos de referência não serem muito exatos, devemos admitir que o valor da inclinação nesse lugar é realmente de poucos metros em 1 quilômetro, no rumo quase sul, dando uma direção $\mathrm{N}-70^{\circ} \mathrm{W}$

Pelo mesmo método, realizando observações de nivelamento direto no vale do arroio Angabal (Município de Taquara, R.G.S.) encontramos uma inclinação para a base de um derrame, de 25 metros para 5 quilômetros rumo sul, com direção $\mathrm{N}-80^{\circ} \mathrm{W}$, conquanto encontrássemos para o derrame inferior, no mesmo local, sòmente 10 metros também rumo sul. Nas cabeceiras do Arroio Forquetina (Município de Lageado, R.G.S.) observa-se inclinação de 12 metros para 2 quilômetros de distancia rumo sudoeste, direção $\mathrm{N}-30^{\circ} \mathrm{W}$.

No Arroio Pinheirinho (Pedra, Município de Araranguá, S.C.) verificamos em duas observações, um mergulho de 4 metros e 6 metros em 3 quilômetros de distância horizontal, rumo norte, direção $\mathrm{N}-30^{\circ} \mathrm{W}$ Esses valores não são absolutos, já devido ao limite de exatidão do método de verificação.

Indicam tais observações um desnível insignificante das soleiras dos derrames considerando-se, ademais, a possibilidade de movimentos isostáticos posteriores terem concorrido para uma diminuição ou aumento dos valores. Chamamos a atenção para o fato de que os valores achados para a inclinação da soleira dos derrames possuem um sentido contrário à inclinação geral do embasamento sedimentar.

Além disso temos ainda evidências de que os movimentos posteriores aos derrames não provocaram inclinações sensíveis. Frequentemente encontram-se amígdalas preenchidas por ágatas horizontais (tipo "Uruguai").

Segundo Nacken (31) formam-se as ágatas do modo seguinte: Soluções difundem-se, sob pressões elevadas, em vesículas vasias. Durante a fase fluida precipita-se a ágata em camadas concêntricas. Atingida a temperatura de $375^{\circ}$ (ponto crítico), for- 
ma-se um sistema de duas fases, gotejando então da emulsão um gel de $\mathrm{SiO}_{2}$ que se sedimenta no fundo em camadas horizontais.

Essas ágatas horizontais nada mais são do que antigos "niveis de bolha" fossilizados. Se as rochas envolventes tivessem sofrido maiores inclinações posteriores, tais ágatas não se achariam mais em posição horizontal, mas também inclinadas. Contudo, todas as inúmeras ágatas observadas no Estado do Rio Grande do Sul, possuindo às vezes 50 centímetros de diâmetro, acham-se com sua estratificação horizontal e, baseados nisso, podemos deduzir que os movimentos ulteriores não provocaram inclinações sensíveis.

\section{b. Texturas fluidais}

Vesículas e amígdalas. - São muito frequentes zonas ricas em vesículas vasias parcial ou integralmente preenchidas, representando as faixas de desgaseificação dificultada pelo resfriamento rápido. São três os tipos principais de vesículas:

1. Esféricas. São muito frequentes, normalmente atingindo apenas 1 centímetro de diâmetro, e tendo aproximadamente 0 mesmo tamanho na mesma faixa. Localizam-se, inferiormente, no. topo do derrame. Sua formação se deu, provàvelmente, na fase de estacionamento do derrame, com o magma parcialmente consolidado. A falta de movimento da lava conservou essas vesículas na sua forma esférica.

2. Ascendentes. São colares de bolhas ou tubos de diâmetros circular e elítico, isolados ou acumulados, que possuem sentido vertical ou inclinado. Representam zonas de desgaseificação com tendências de escapamento na superfície. Frequentemente chegam à zona superficial do derrame ou terminam em uma amígdala maior, de alguns decímetros de tamanho. $\mathrm{O}$ maior tubo observado media 2 metros de comprimento, com um diâmetro variável entre 1 e 3 centímetros, no túnel do Salto (Canela, R.G.S.). A zona dos tubos e colares ascendentes situa-se normalmente entre os basaltos com vesículas esféricas e os com vesículas achatadas. Du Toit (7) descreve fenômenos semelhantes nos derrames sulafricanos.

3. Elipsoides. São vesículas alongadas com dois ou, normalmente, três diâmetros diferentes, de tamanho muito variável, entre milímetros e decímetros. Na maioria dos casos o seu comprimento oscila em torno de 1 centímetro. Estas vesículas podem estar vasias, ou apresentar as paredes revestidas, ou ainda, estar preenchidas. Devemos admitir que a sua forma achatada e alongada provém de uma geração ocorrida durante o corrimento da lava, com alongamento no sentido da corrida. Corroborariam tal suposição os poucos fenocristais encontrados nessa zona vesicular com a mesma orientação. Essas vesículas representam verdadeira textura fluidal. E' interessante notar que os eixos maiores acham- 
TABELA N.9 2

\section{Díreções das texturas fluidais}

\begin{tabular}{|c|c|c|c|}
\hline Localidade & $\begin{array}{l}\text { Direção } \\
\text { máxima }\end{array}$ & Total das & $\begin{array}{l}\text { Observações } \\
\text { no setor do } \\
\text { "máximo" }\end{array}$ \\
\hline $\begin{array}{l}\text { 1- Araranguá (Pedra) } \ldots . . . \cdots \\
\text { Santa Catarina }\end{array}$ & $\mathrm{N} 15^{\circ} \mathrm{E}$ & 212 & 102 \\
\hline $\begin{array}{l}\text { 2- Araranguá (Arroio Manoel).. } \\
\text { Santa Catarina }\end{array}$ & $\mathrm{N} \quad \mathrm{S}$ & 189 & 111 \\
\hline $\begin{array}{l}\text { 3- Tainhas (Faxinal) } \ldots \ldots \ldots \ldots \\
\text { Rio Grande do Sul }\end{array}$ & $\mathrm{N} 60^{\circ} \mathrm{E}$ & 239 & 115 \\
\hline $\begin{array}{l}\text { 4- Canela (Salto) } \ldots \ldots \ldots \ldots \ldots \ldots \\
\text { Rio Grande do Sul }\end{array}$ & $\mathrm{N} 45^{\circ} \mathrm{E}$ & 256 & 165 \\
\hline $\begin{array}{l}\text { 5- Bom Jesus } \ldots \ldots \ldots \ldots \ldots \ldots \ldots \\
\text { Rio Grande do Sul }\end{array}$ & $\mathrm{N} 60^{\circ} \mathrm{E}$ & 112 & 77 \\
\hline $\begin{array}{l}\text { 6- Chapéu (Rio Tainhas) } \ldots \ldots \\
\text { Rio Grande do Sul }\end{array}$ & N450 $\mathrm{E}$ & 138 & 68 \\
\hline $\begin{array}{l}\text { 7- Farroupilha } \ldots \ldots \ldots \ldots \ldots \ldots \ldots \\
\text { Rio Grande do Sul }\end{array}$ & $\mathrm{N} 45^{\circ} \mathrm{E}$ & 150 & 97 \\
\hline $\begin{array}{l}8 \text { - Guaporé } \quad \ldots \ldots \ldots \ldots \cdots \cdots \cdots \cdots \\
\quad \text { Rio Grande do Sul }\end{array}$ & $\mathrm{N} 60^{\circ} \mathrm{E}$ & 211 & 102 \\
\hline $\begin{array}{l}\text { 9- Carasinho (Selbach) } \ldots \ldots \ldots \ldots \\
\text { Rio Grande do Sul }\end{array}$ & $\mathrm{N} \quad \mathrm{S}$ & 188 & 83 \\
\hline $\begin{array}{l}10 \text { - Santa Maria (Pinhal) } \ldots \ldots \\
\text { Rio Grande do Sul }\end{array}$ & $\mathrm{N} 15^{\circ} \mathrm{W}$ & 207 & 94 \\
\hline $\begin{array}{l}11 \text { Iraí } \quad \ldots \ldots \ldots \ldots \ldots \ldots \ldots \ldots \\
\text { Rio Grande do Sul }\end{array}$ & $\mathrm{N} 15^{\circ} \mathrm{W}$ & 161 & 96 \\
\hline $\begin{array}{l}12 \text { - São Luiz (Guaramano) } \ldots \text {... } \\
\text { Rio Grande do Sul }\end{array}$ & $\mathrm{N} 75^{\circ} \mathrm{W}$ & 187 & 81 \\
\hline $\begin{array}{c}13 \text { - São Francisco de Assis } \ldots . . \\
\text { (Ibicui) Rio Grande do Sul }\end{array}$ & $\mathrm{N} 45^{\circ} \mathrm{W}$ & 197 & 76 \\
\hline
\end{tabular}


se no plano horizontal e apenas em poucos lugares observam-se posições não horizontais, permitindo inferir movimentos turbilhonares. Deduz-se daqui, também, que as corridas de lavas se deram em planos e superfícies pràticamente horizontais.

Medimos em vários lugares, a direção do eixo maior das vesículas, com intúito de inferir as direções da corrida da lava. E' óbvia a precariedade do método, sobretudo pela insignificância das observações, tendo-se em conta a vastidão da área. Em cada um dos lugares estudados, foram medidas cerca de 200 vesículas, sendo que os pontos observados montam a 13. Devemos ainda acrescentar que as observações não se realizaram em um único derrame. Alguns resultados são representados nos gráficos (Fig. 10, 11) e seu conjunto na Tabela n. $^{0} 2$.

Pelos gráficos (Fig. 10,11) percebe-se que há certa dispersão dos valores, porém com um máximo nítido. Para o caso dessas texturas fluidais não é possível, naturalmente, verificar o sentido das direções, dado o fato de que os derrames se realizaram em planos pràticamente horizontais.

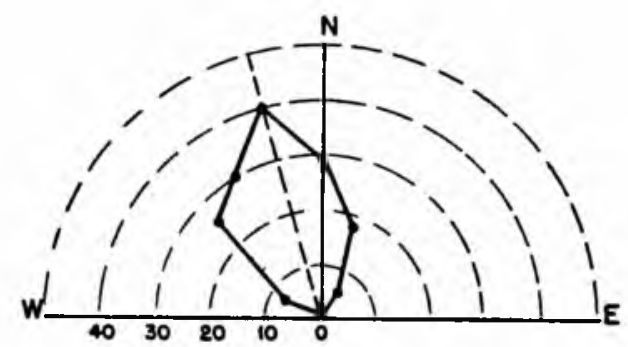

Irai-R.G.S. Direçōo N $15^{\circ} \mathrm{W}$

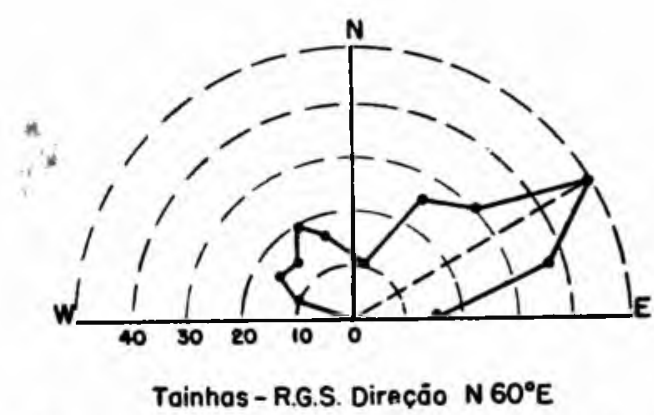

$\begin{array}{lll}\text { Fig. } 10 \text { - Direção das texturas flui- } & \text { Fig. } 11 \text { - Direcão das texturas } \\ \text { dais; Iraí, Rio Grande do Sul. } & \text { fluidais: Tainhas, Rio Grande do Sul }\end{array}$

$\begin{array}{lll}\text { Fig. } 10 \text { - Direção das texturas flui- } & \text { Fig. } 11 \text { - Direcão das texturas } \\ \text { dais; Iraí, Rio Grande do Sul. } & \text { fluidais: Tainhas, Rio Grande do Sul }\end{array}$

Os gráficos representam os valores observados de $15^{\circ} \mathrm{em} 15^{\circ}$. Os círculos indicam o número das observações, a direção predominante e o número total das observações no setor do máximo. Este setor abrange $30^{\circ}$, isto é, $15^{\circ}$ de cada lado do máximo.

Os resultados mostram a existência de dois rumos diferentes (Fig. 13) Para a maior parte das observações, as texturas fluidais situam-se nos quadrantes NE-SW Dispõem-se ligeiramente oblíquas em relação à linha tectônica Torres-Posadas. Cremos que o sentido das corridas de lava no caso é o afastamento bilateral dessa linha tectônica. Esta opinião está baseada em considerações tectônicas, etc.

O segundo grupo de direções, pouco representado, indica direções perpendiculares ao rio Uruguai. Possivelmente a região deste rio teria sido a fornecedora de lava para as áreas com texturas fluidais W-E. Neste caso, ó sentido das corridas dos derrames indicaria rumo Este. Trataremos deste problema, em conjunto, nas páginas 53-55. 


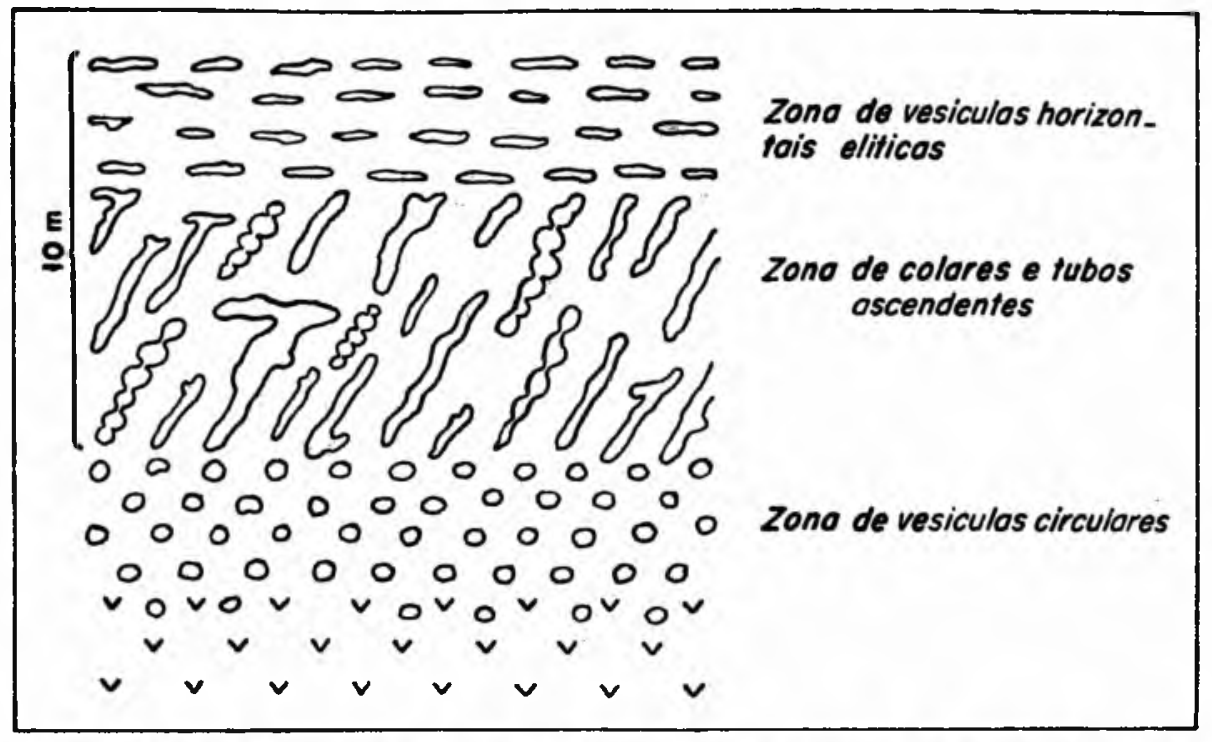

Fig. 12 - Esquema da distribuição das vesículas num derrame.

\section{ATIVIDADES EXPLOSIVAS}

Muito raras são as observações indicando fenômenos produzidos por fases explosivas. Assim, Washburne (46) descreve a ocorrência de bombas vulcânicas angulosas de basalto amigdaloide em Botucatú (S. P.). Almeida (1) em Mato Grosso e Plinio

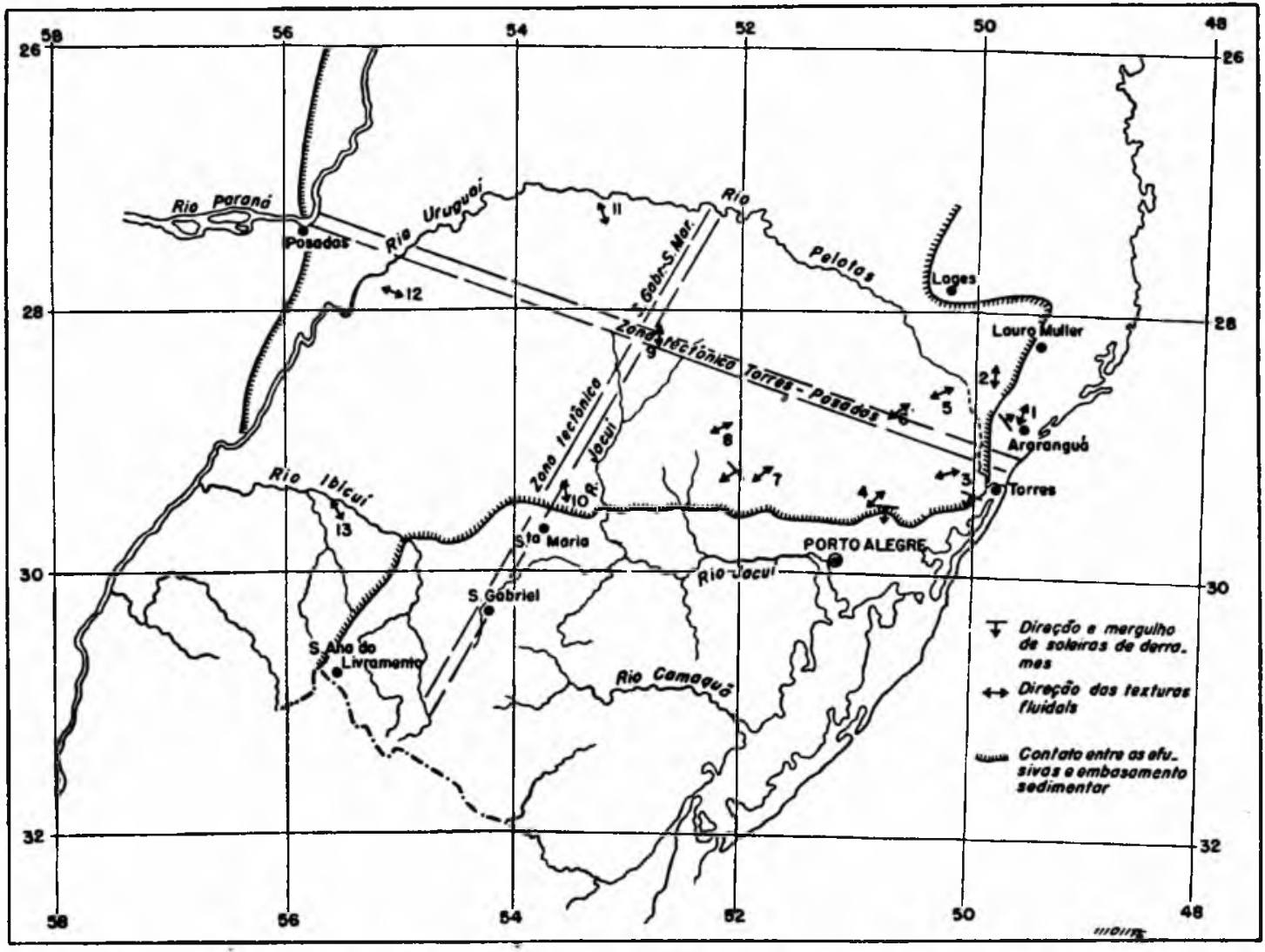

Fig. 13 - Mapa indicando as direções fluidais e as direções das "soleiras" 
de Lima (informação verbal) no município de Guarapuava (Paraná) citam ocorrências semelhantes. Quanto a esta última referência, Lima acredita tratar-se de uma ocorrência de vários quilômetros de extensão. Notam-se nas amostras fragmentos angulosos de vários centímetros de diâmetro de basalto amigdaloidal, cimentado por uma massa finíssima de côr verde escura composta de material cinerítico e argila detrítica parcialmente zeolitizada. (Fot. 5).

No Rio Grande do Sul, Azambuja (2) descreve um arenito vulcanoclástico, colecionado por nós nos arredores de Iraí, e referido por aquele autor a uma fase explosiva, - fornecendo uma espécie de "lapilli" sedimentado juntamente com material clástico. A ocorrência desse sedimento vulcanoclástico, intercalado a dois derrames basálticos ocupa, sem dúvida, uma área de alguns quilômetros quadrados.

São essas as poucas ocorrências conhecidas sobre indícios de atividades explosivas. Maior número de estudos provàvelmente ampliarão o número de ocorrências. Nessas três conhecidas há entretanto, um fato comum: a existência exclusiva de material basáltico, vítreo ou amigdaloide como produto explosivo, misturados a areias e argilas clásticas. Indica o fato que as explosões se realizaram não nas regiōes profundas e sim nos próprios derrames.

E' provável que tais produtos piroclásticos provenham de explosões locais dos derrames solidificados na superfície, mas ainda em fusão no centro. O acúmulo de gases represados pela crosta já consolidada teria provocado as explosões, rompendo-se as crostas amigdaloides ou vítreas, assim se originando como que pequenos vulcões "embrionários" muito conhecidos nas corridas de lava atuais havendo, por outro lado, mistura de material expulso com o material sedimentar em vias de formação.

Quaisquer indícios de uma atividade explosiva regional e profunda comuns ao vulcanismo atual, não foram encontrados e não esperamos encontrar.

\section{INTRUSIVAS - DIQUES E SILLS}

Dentre as manifestações secundárias mais importantes da atividade vulcânica estão as ocorrências de inúmeros diques e sills de diabásio da orla dos derrames. Cortam e se intrometem em sedimentos gondwânicos preexistentes, bem como atravessam, em parte, também o "cristalino". Toda ocorrência de dique de diabásio é admitida, em geral, como ligada ao vulcanismo triássico. Tal admissão é sem dúvida fundamentada quando se tem em consideração a idade dos sedimentos envolvidos. Parece-nos, contudo, uma generalização demasiada para os casos onde apenas foi atingido o cristalino. E' muito provável que parte dos diabásios que 
atravessam o cristalino nada tenha a vêr com as atividades "triássicas" Assim, no sul do Estado de São Paulo, na região de Capão Bonito-Apiaí, ocorrem numerosos diques de diabásio no cristalino, ao passo que rareiam e até se ausentam nos sedimentos gondwânicos lindeiros. Tal disparidade de ocorrência indica que o cristalino foi afetado por diques de diabásio-gabro, em épocas anteriores. O estudo microscópico poderia oferecer um critério para distinção: é possível que os diabásios antigos já apresentassem alguma modificação mineralógica ou particularidade textural.

Nos derrames verdadeiros não se encontra material de textura ofitica, que é característica nas formas de sills e diques, seus contemporâneos. Já a olho nu observa-se normalmente sua constituição granular característica. Só os diques e sills com espessuras de poucos metros mostram, em geral, textura microcristalina, com presença de vidro em pequena escala.

O número de diques e sills atravessando os sedimentos gondwânicos é grande. Assim, no município de São Pedro (S. P.) foram realizados, segundo Oppenheim (34) 18 furos nos quais se encontraram de 8 a 9 intercalações de diabásio ocorrendo, provàvelmente, sob forma de sill. Os sills localizam-se de preferência no nível dos sedimentos calcíferos da Formação Iratí. Assim registra-se um grande número de sills, no Estado de São Paulo, justamente nas regiões onde aflora o "Irati". Em 17 sondagens realizadas no sul do Brasil encontraram-se intercalações de sill, 11 das quais estão localizadas no Iratí e 4 na Formação Estrada Nova. E' pouco provável que a natureza calcárea dos sedimentos do grupo Passa-Dois houvesse facilitado a intrusão do magma sob forma de sill.

O número de diques e sills, sua frequência e provàvelmente a sua importância, aumenta ràpidamente nas proximidades dos derrames. Assim Maack (28) observou no sul de Santa Catarina 15 diques paralelos numa distância de-cerca-de 20 quilômetros. Aliás esta área é das mais ricas em número de diques em todo o sul do Brasil. Situa-se justamente na linha tectônica Torres-Posadas. Como outro exemplo de frequência de diques citaremos o caso de Piracicaba-São Pedro (S. P.) onde afloram 8 diques em 40 quilômetros de distância.

Interessante é a ausência, quase completa, de diques e sills na orla dos derrames no Rio Grande do Sul. Mesmo nas visinhanças dos derrames não se observa qualquer atividade intrusiva do magma basáltico. Em dezenas de quilômetros de extensão aparece, por vezes, um dique de pequena espessura; exatamente ao contrário do que se observa mais para o norte, de Torres para Cresciuma.

As espessuras, tanto dos sills como dos diques, são muito variáveis. Os sills atravessados por sondagens possuem espessuras variando de 10 metros a 180 metros No município de São Pedro foi encontrado, em 8 sondagens, um sill intrometido entre o Iratí 
e o Tubarão. A situação destas sondagens indica que se trata de um sill único e contínuo, cuja espessura varia de 70 a $180 \mathrm{me}-$ tros. A área por ele ocupada deve ser bem grande, pois numa linha de 5 quilômetros foi registrado em 5 sondagens. Possui, provàvelmente, uma área total de várias dezenas de quilômetros quadrados. Mais fácil é a verificação da espessura dos diques. Varia de metros a dezenas de metros. Naturalmente varia também em comprimento. O maior observado por nós, situa-se ao norte de Araranguá (S. C.) e tem pelo menos 10 quilômetros de extensão, rumo $\mathrm{N}^{\circ} \mathrm{W}$, possuindo a considerável espessura de $100 \mathrm{me}-$ tros. Raras vezes observa-se um comprimento superior a 1 quilômetro. As direções são relativamente constantes, segundo dois sistemas principais, WNW e NE. Às vezes, os diques formam zigue-zagues, acompanhando um trecho de um sistema para cair em seguida na direção do outro sistema. No sul de Santa Catarina, dos 20 diques observados, 16 possuiam a direção ao redor de $\mathrm{N}-60^{\circ} \mathrm{W}$ e $4 \mathrm{~N}-20^{\circ} \mathrm{E}$. Geralmente, os diques cortam verticamente ou quase verticalmente as camadas encaixantes.

O metamorfismo de contacto entre os sedimentos e a rocha intrusiva é relativamente insignificante, mas bem superior aos produzidos por contactos com os derrames. Um dique de diabásio de 5 metros de possança atravessa, perto de Piracicaba (S. P.), sedimentos argilosos do Estrada Nova. Observa-se uma zona de 20 centímetros de sedimento adenolisado diretamente em contacto; depois segue-se uma zona de 3 metros de folhelho endurecido, de côr cinza-azulada que passa, gradativamente, ao folhelho avermelhado comum.

O sill de São Pedro, com cerca de 80 metros de espessura, provocou na sua capa uma recristalização parcial do calcáreo, com expulsão de parte do material orgânico. Os folhelhos intercalados mostram apenas um endurecimento, sem recristalização visível ao microscópio. A zona com influência perceptível da vizinhança do magma atinge aí cerca de 20 metros.

Nas páginas 52,53 serão tecidas considerações sobre a origem das formas intrusivas.

Mais reduzido ainda é o endomorfismo. Raras vezes encontram-se grãos de quartzo clástico parcialmente assimilados nos diabásios. O próprio calcáreo, geralmente assimilável, não influenciou o magma intrusivo. Apenas numa zona de contacto de 1 centímetro de espessura puderam ser encontrados cristais de epídoto. A granulação dos diabásios pouco depende da vizinhança do contacto. Apenas uma faixa de poucos centímetros mostra textura vítrea, passando ràpidamente à textura microcristalina; a ela sucede logo, a cerca de 1 metro, a granulação normal milimétrica.

Perto de Uruçanga (S. C.), aflora um sill gigantesco, afastado 15 quilômetros a Este da escarpa dos derrames. Rocha e Scorza (39) descreveram e mapearam pormenorizadamente essa ocorrência. Interpretaram-na, porém, não como um sill exposto e 
sim como derrame basáltico. Este sill forma um acidente topográfico muito pronunciado, o "Montanhão", com cerca de 300 metros de elevação sobre a região e cerca de 500 metros de altitude. O embasamento é formado pelos sedimentos da série Tubarão. Acima desta série acha-se espessa camada de rochas de caráter diabásico, que ocupa uma área contínua de-cerca-de 20 × 5 quilômetros. $\vee \mathrm{A}$ classificação de sill é comprovada pela textura ofítica e ausência absoluta de qualquer textura efusiva (amigdalovesicular, vítrea, basáltica, etc.). Acresce ainda, como prova de que se trata de sill, a sua posição estratigráfica, isto é, estar assentado sobre a série Tubarão e não sobre os arenitos do Botucatú. Já lembrámos que a zona dos estratos "Iratî" é justamente a privilegiada para a formação de sills (Fig. 14.) $\lambda$

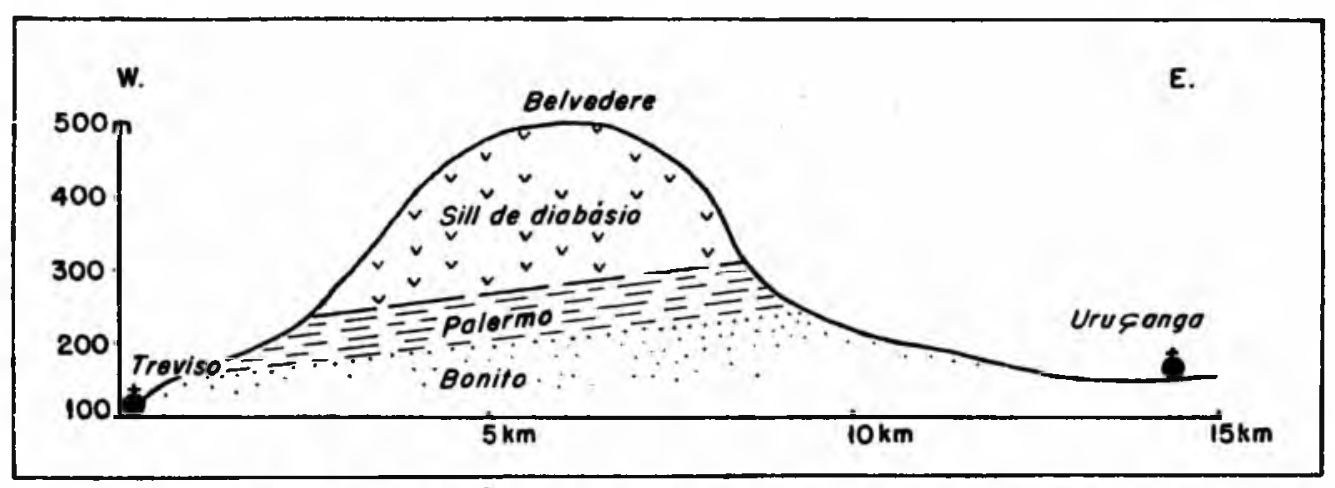

Fig. 14 - Perfil geológico do sill no nível da formação "Tubarão", aflorando entre Treviso e Uruçanga, Santa Catarina.

O metamorfismo de contacto é insignificante. Os folhelhos arenosos e de coloração cinza tornam-se escuros e mais compactos, mas sem recristalização visível ao microscópio. A auréola visível é de 10 metros apenas.

Outro sill gigantesco aflora na região de Piracicaba (S. P.), segundo informação verbal de $O$. Barbosa e $F$ de Almeida. Sua área extende-se, hoje, até cerca de 900 quilômetros quadrados com a espessura por volta de 150 metros. Este sill também está situado na base do Iratí.

Até agora só registramos um único dique atravessando as efusivas, na subida do vale Carvalho (Três Forquilhas, R.G.S.). Aqui, um derrame rico em vidro e possuindo diaclases horizontais pronunciadas é cortado por possante dique holocristalino, de textura ofítica, com pronunciadas diaclases verticais poligonais. Tanto as diaclases como a textura holocristalina permitem distinguir fàcilmente o dique do derrame encaixante (Fig. 15). A espessura é de 50 metros, a direção $\mathrm{N}-70^{\circ} \mathrm{W}$ e o mergulho vertical. Não foi possível observar se o dique corta todos os derrames superiores, ou se termina num deles. E' interessante notar que até agora não foram mencionados, na literatura, outros diques atravessando efusivas. Naturalmente há para isso necessidade da ocorrência de 
afloramentos mais adequados à observação. Admite-se, por outro lado, a existência de certo número de diques atravessando os derrames inferiores. Os derrames sucessivos são formados pela extrusão de lava através das fendas que são preenchidas na fase final pelo magma consolidado.

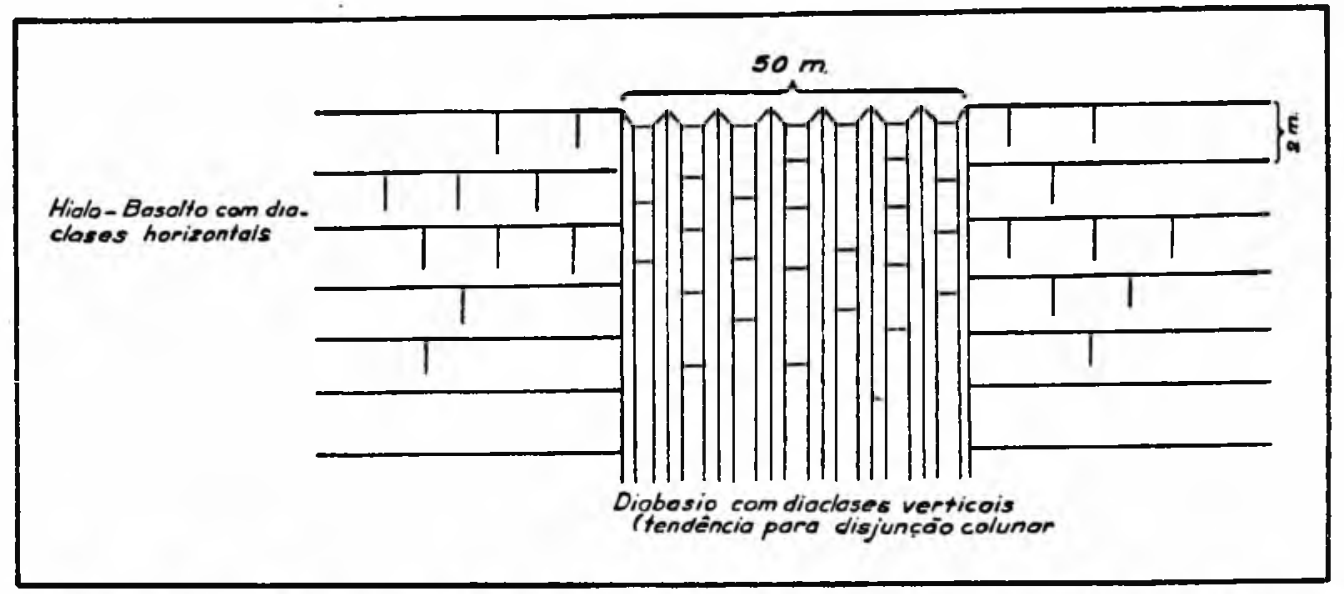

Fig. 15 - Esquema de um dique de diabásio atravessando um derrame basáltico; Vale Carvalho-Três Forquilhas, Rio Grande do Sul

A escassês de tais ocorrências é explicada, em parte, pela dificuldade de observação; em parte, também, porque aparentemente as fendas e os diques teriam sido numèricamente reduzidos, em-

- bora espessos e limitados a certas zonas. Os inúmeros diques, pequenos e fàcilmente observáveis na região sedimentar, não correspondem aos antigos canais de alimentação. Tratar-se-iam de diques secundários, parcialmente provenientes dos sills. As fendas e o produto final consolidado nos diques de alimentação devem ser de dimensões respeitáveis. São de difícil observação em afloramentos pequenos ou em rochas encaixantes de aspecto semelhante.

\section{PETROLOGIA DAS EFUSIVAS}

\section{TEXTURA E VARIAÇÕES PETROGRÁFICAS}

Nossos atuais conhecimentos petrográficos sobre as rochas vulcânicas triássicas são muito mais profundos que os conhecimentos geológicos, graças aos trabalhos de D. Guimarães (12, 13, 14), Hussack $(18,19)$, Walter $(44,45)$ e Almeida (1) Neles são descritas, pormenorizadamente, as variações mineralógicas, texturais e químicas das rochas. Há entretanto - como aliás na literatura geral - certa divergência de nomenclatura devido às variações texturais e a nomenclatura infeliz de Rosenbusch, que ligou a sistemática às idades geológicas.

Seguiremos aqui a nomenclatura americana adotada também por Almeida (1). Distinguem-se, nitidamente, 2 tipos de rochas: 
diabásio, caracterizado por uma composição gabróide, de textura ofítica e basaltc, caracterizado pela presença de mesostasis em quantidade variável.

Assim, o diabásio representa todos os termos intrusivos do magma basáltico, tais como diques, sills, etc. De fato, nossas rochas intrusivas possuem exclusivamente texturas ofiticas, exceto em pequenas faixas de contacto onde a textura intersticial pode aparecer. Nenhuma rocha proveniente de derrames possui textura ofítica, mesmo no interior dos derrames espesssos.

As rochas dos derrames pertencem aos basaltos - exceto, naturalmente, as rochas de composição química diversa e bem por isso mineralògicamente muito diferente, como os leidleítos. Observámos apenas variações nos teores de vidro e maior ou menor tendência para textura porfirítica, cuja origem é bem explicada por Almeida (1). As variações dos teores de vidro são consideráveis, de $10 \%$ até $70 \%$ do volume total de uma rocha.

Caracterizam-se, portanto, as rochas efusivas basálticas, pelo seu conteúdo de plagioclásio de teor variável entre $50-70 \%$ An e piroxênio (augita e pigeonita) como elementos principais. Como accessórios, observam-se magnetita, magneto-ilmenita e, raras vezes, apatita. Além desses minerais, ocorre sempre, em quantidade variável, material vítreo com índice variando entre 1,54 e 1,57 Este material frequentemente se apresenta desvitrificado. Não consideramos aqui os constituintes secundários e os minerais de preenchimento das vesículas.

$$
* * *
$$

Não se encontra um hiato na cristalização, o que indica a inexistência de 2 gerações de cristais de formação intra e extratelúrica. Todos os cristais foram formados na fase extratelúrica (olivina?). Assim observa-se que os cristais imersos em vidro ("fenocristais") aumentam gradativamente em tamanho e, às vezes, em número, da borda para o centro de um derrame. Se existissem fenocristais verdadeiros, "intratelúricos", eles deveriam ser encontrados uniformemente dispersos e com tamanho idêntico em qualquer ponto de uma corrida de lava. Não se verificaria tal dependência dos cristais para a superfície e o centro do derrame.

Numa fusão basáltica, com densidade aproximada de 2,9, não se explicaria também esse enriquecimento de "fenocristais" de feldspato nas partes internas de um derrame, por sedimentação dos cristais formados. Lembramos apenas que a densidade do plagioclásio é inferior à da fusão. Um basalto com fenocristais nada mais é que uma fase incipiente de cristalização durante e principalmente após a efusão, não podendo atingir seu termo estrutural final "intersticial" devido ao resfriamento demasiadamente rápido.

Tudo indica que a lava ascendeu em estado de completa fusão, isto é, sob temperatura muito elevada. 
Um tipo de rocha diferente dos basaltos foi encontrado no alto de Três Forquilhas (R.G.S.) e em Faxinal (Tainhas, R.G.S.), possuindo composição química muito mais ácida e alcalina. Guimarães (12) descreveu rochas semelhantes, dando-lhes o nome de "leidleíto". As análises químicas dessas rochas (17, 18 da Tabela n. ${ }^{\circ}$ 3) são muito semelhantes à analisada por Guimarães. Macroscòpicamente possuem o aspecto de vidro vulcânico, exibem fratura conchoidal, côr preta até verde escura e mostram poucos cristais milimétricos visíveis. Na ocorrência citada, a rocha faz parte dos últimos derrames e deve ocupar, no mínimo, várias dezenas de metros de espessura.

Microscòpicamente, encontra-se cerca de $50-70 \%$ de vidro vulcânico, de côr castanho-esverdeada com índice de refração 1.52. Todos os minerais são frescos, predominando bastonetes idiomorfos de plagioclásio com cerca de $50 \%$ An e augita (?) Apatita e magnetita são muito raras. A composição quantitativa das amostras analisadas é a seguinte:

\begin{tabular}{|c|c|c|}
\hline Análises & N. ${ }^{\circ} 17$ & N. ${ }^{\circ} 18$ \\
\hline $\begin{array}{llll}\ldots & \ldots & \ldots & \ldots\end{array}$ & $64 \%$ & $71 \%$ \\
\hline $\begin{array}{lll}\ldots & \ldots & \ldots\end{array}$ & 26 & 23 \\
\hline $\begin{array}{llll}\cdots & \ldots & \ldots & \ldots\end{array}$ & 8 & 5 \\
\hline Magnetita e Apatita & 2 & 1 \\
\hline$\ldots \quad \ldots \quad \ldots$ & 2,7 & 2,7 \\
\hline
\end{tabular}

A massa fundamental possui, potencialmente, andesina + ortoclásio + quartó + augita.

Guimarães (12) encontrou, em uma das amostras estudadas de leidleíto, nefelina, não registrada por nós.

E muito provável que esse leidleíto ou hialo-dacito possua áreas de ocorrência consideráveis nos Estados do Rio Grande do Sul e Santa Catarina.

\section{VARIAÇÕES PETROGRÁFICAS NO PERFIL TRES FORQUILHAS-TAINHAS, R. G. S.}

Os melhores afloramentos de derrames basálticos hoje accessíveis, acham-se no percurso de uma nova rodovia que vai de Três 
Forquilhas até o alto da Serra de Tainhas, no Estado do Rio Grande do Sul. Em cerca de 12 quilômetros de percurso a estrada galga a quase 900 metros de altitude, talhada em bôa parte em rocha fresca. Tem-se, aqui, um perfil contínuo e quase completo dos derrames sucessivos. A estrada fornece melhores afloramentos que a antiga "Estrada Nova" de White, que vai de Lauro Müller para São Joaquim (Sta. Catarina). Fizemos o levantamento minucioso no perfil Três Forquilhas-Tainhas, colhendo amostras de 25 em 25 metros de altitude e analisando-as ao microscópio. Visámos estudar: $10^{\circ}$ As variações quantitativas da massa vítrea. $20^{\circ}$ As variações quantitativas dos fenocristais isolados. 3. ${ }^{\circ}$ As variações grosseiras da composição mineralógica.

$1 .^{\circ}$ As variações quantitativas da massa vítrea são consideráveis. Por conveniência denominamos rocha vítrea todo material com mais de $50 \%$ de vidro, mesmo parcialmente desvitrificado. Destacase, já, a olho nu, pelo seu brilho de pixe, textura afanítica e fratura conchoidal. Na figura 16 representamos estas

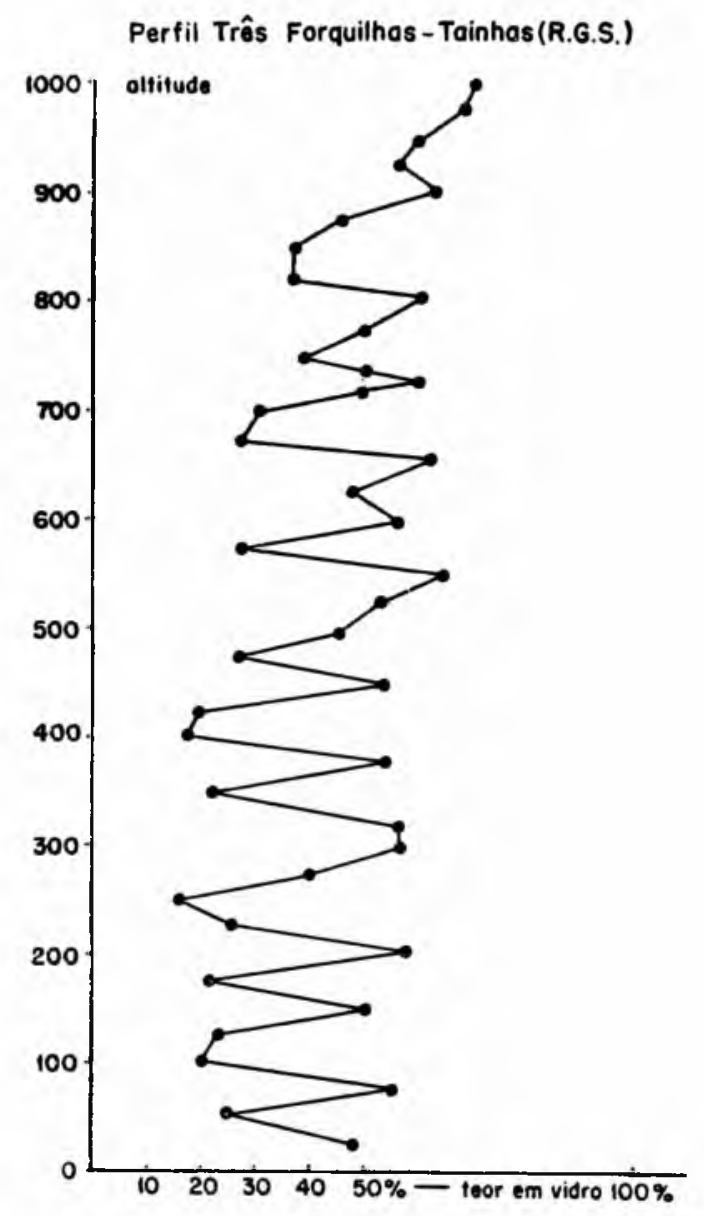

Fig. 16 - Variações do teor em vidro das efusivas no perfil Três ForquilhasTainhas, Rio Grande do Sul. variações gràficamente. Nota-se nela a inexistência de rochas holocristalinas. A massa vítrea é sempre encontrada em quantidade variável; grande número de amostras apresenta teores superiores a 50\%. São precisamente esses máximos que nós consideramos como indicadores de hiato entre os derrames. No gráfico não se destacam as rochas vítreas compactas, das "amígdalo-vesiculares" (melafíricas) porque ambas possuem considerável teor em vidro, ssto é, tanto a soleira como a superfície de um derrame. O gráfico mostra, também, que a quantidade da massa vítrea aumenta consideràvelmente na parte superior do perfil na região dos "hialo. dacitos"

2. $\quad$ As variações quantitativas dos fenocristais mostraram-se absolutamente independentes do teor de vidro. Mas dentro do intervalo de $70-40 \%$ de vidro não se observa maior quantidade de 
cristais isolados, e sim um tamanho maior quanto menor fôr a massa vítrea. Sòmente teores de massa vítrea superiores a $40 \%$ acusam "fenocristais" isolados. Teores inferiores são caracterizados por aglomerações de minerais, nos quais um ou outro cristal possui um tamanho maior que o resto, mas sem se tornar "fenocristal" Isso indica claramente que fenocristais nada mais são que núcleos de cristalização incipiente, tanto mais desenvolvidos quanto menor fôr o teor em vidro, isto é, com um resfriamento lento do magna in situ. Trata-se, assim, exclusivamente de cristalização extratelúrica. A textura fluidal, frequente nos termos vesiculares, provocada por orientação dos cristais, denuncia que a cristalização já se iniciára durante a corrida da lava. O tamanho dos fenocristais varia entre $0,02 \mathrm{~mm}$ e $0,2 \mathrm{~mm}$, sendo $0,1 \mathrm{~mm}$ muito frequente. Os minerais que formam fenocristais são plagioclásio e augita, dos quais o plagioclásio atinge normalmente o dobro do tamanho da augita. Ambos estão sempre presentes, observando-se apenas predominância da quantidade de plagioclásio sobre a augita em volta de $3: 2$.

3. Mudanças mineralógicas consideráveis não foram observadas mesmo na faixa de leidleíto, onde se encontram tanto plagioclásios como também augita, semelhantes aos dos basaltos. Sòmente o índice de refração do vidro baixa de 1,56 nos basaltos, para 1,52. E interessante notar que na região dos leidleítos ocorrem zonas de 10-20 metros de espessura, nas quais a rocha normalmente escura torna-se avermelhada e atravessada por uma rede de faixas esbranquiçadas (Fot. 6) A tonalidade avermelhada é provocada pela oxidação do pigmento de magnetita comum para hematita, enquanto nas faixas brancas desaparece a hematita. Parece-nos que se trata de oxidação e lixiviação do leidleíto por percolação no sentido ascendente de gases e soluções automagmáticas.

\section{COMPOSIÇÃO QUÍMICA DAS EFUSIVAS BASÄLTICAS}

Poucas são as análises químicas disponíveis das efusivas basálticas brasileiras. Ademais em bôa parte são análises provenientes de sills e diques, e portanto de diabásios. No total são apenas 18, das quais 4 novas. A maioria das análises é dada por Guimarães (12) em seu trabalho pioneiro dos resultados químicos. Observam-se aqui, nitidamente, 2 grupos com quimismo diferente. $\mathrm{O}$ primeiro, com 15 representantes, possui teor em $\mathrm{SiO}_{2}$ oscilando entre $46 \%$ e $55 \%$ e o segundo entre $61 \%$ e $66 \%$.

$O$ primeiro grupo (análises 1-15 na tabela n. ${ }^{\circ} 3$ ) possui as variações principais dadas na tabela n. ${ }^{\circ} 4$ Pela tabela n. 4 ressalta a semelhança das efusivas do sul do Brasil com as do sul da África e com as da India, como também sua semelhança com o "basalto" protótipo dado por Tröger (42) As discrepâncias são insignificantes, fàcilmente visíveis na tabela dos valores de Niggli. 
A maior divergência está nos valores $\mathrm{fm}$ alto e valor $\mathrm{c}$ baixo no caso. das rochas brasileiras, em virtude do enriquecimento em piroxênio em detrimento dos plagioclásios. Estes valores são apenas ligeiramente discrepantes. Conclui-se, portanto, que a maior parte das efusivas admitidas como triássicas deve ser incluida entre os basaltos verdadeiros de Tröger (42), possuindo composição pràticamente idêntica à das rochas de outros derrames gondwânicos e aproximadamente sincrônicas.

$O$ segundo grupo (das efusivas brasileiras) é representado apenas por 3 análises nos ns. 16 a 18 da tabela n. 3 . Estas três análises fornecem os seguintes valores médios:

$\begin{array}{lrrc}\mathrm{SiO}_{2} & 64,3 & \text { Valores } & \text { Niggli } \\ \mathrm{Al}_{2} \mathrm{O}_{3} & 13,6 & & \\ \mathrm{FeO} & 4,2 & \mathrm{si} & 2.56 \\ \mathrm{Fe}_{2} \mathrm{O}_{3} & 2,3 & \text { al } & 32.0 \\ \mathrm{MgO} & 2,1 & \text { fm } & 33.5 \\ \mathrm{CaO} & 3,8 & \mathrm{c} & 16.0 \\ \mathrm{~K}_{2} \mathrm{O} & 3,1 & \text { alk } & 18.5 \\ \mathrm{Na}_{2} \mathrm{O} & 2,7 & \text { ti } & 3.0 \\ \mathrm{TiO}_{2} & 1,0 & \mathrm{mg} & 0.27 \\ \mathrm{P}_{2} \mathrm{O}_{5} & 0,15 & \text { k } & 0.43 \\ \mathrm{H}_{2} \mathrm{O}+ & 2,6 & \text { p } & 0.3 \\ \mathrm{H}_{2} \mathrm{O} & 0,5 & & \end{array}$

D. Guimarães (12) estuda uma rocha desse tipo, proveniente do Rio Grande do Sul, designando-a leidleíto. De fato a composição química das 3 análises (16-18) aproxima-se muito de um leidleíto, isto é, um hialo-dacito. Característico para esta rocha é o seu alto teor em $\mathrm{H}_{2} \mathrm{O}^{+}$, provocado pelo alto teor - até $70 \%$ - de vidro. Outro característico é o seu alto teor em potássio não fixado nos minerais existentes e sim na base vítrea. $O$ teor em ferro e magnésio é muito baixo e o de sílica muito alto em relação aos basaltos.

E interessante observar que apenas rochas ricas em material vítreo possuem tal composição divergente dos basaltos comuns, que constituem a massa das efusivas. A interpretação da causa desta divergência na composição química entre basaltos comuns, quase holocristalinos e sua variante quase vítrea, é duvidosa e merece estudo petrológico acurado. Parece que se devem considerar 3 possibilidades: 1) $\mathrm{O}$ quimismo dos hialo-dacitos corresponde à composição do magma. 2) Houve imigração e fixação principalmente de $\mathrm{SiO}_{2}, \mathrm{~K}_{2} \mathrm{O}$ e $\mathrm{Na}_{2} \mathrm{O}$. 3) São o produto de uma diferenciação, partindo de uma composição básica, para a ácida-alcalina talvez acentuada devido a uma assimilação.

Como até agora não foi encontrada rocha cristalina com uma composição semelhante aos hialo-dacitos, acreditamos que a hipótese de uma diferenciação comum e exclusiva, é a menos provável. 
A diferença química deve ter ligação, em parte, com o estado vítreo da rocha. Ou ela reabsorveu sílica e álcalis provenientes da distilação magmática dos derrames subjacentes, e neste caso também - magma era ligeiramente mais ácido e alcalino que os basaltos, ou a consolidação brusca do magma não permitiu a eliminação lenta destes elementos, como aconteceu durante a cristalização dos basaltos.

Parece-nos mais provável admitir a hipótese de que houve realmente absorção de sílica e álcalis, tendendo para o estado ácidoalcalino, porque todas as amostras de leidleitos provêm do último ou penúltimo derrame conservado. Um hialo-basalto de Três Forquilhas, proveniente de um derrame relativamente antigo (Anal. 13) acusa, apesar do seu alto teor em vidro (50\%), composição basáltica com $\mathrm{SiO}_{2}$ ligeiramente superior à comum .

Essa tendência no sentido ácido, no caso dos leidleitos, acentuou-se mais devido à impossibilidade de eliminação das soluções ricas em sílica e álcalis pelo resfriamento brusco comum nos termos cristalinos. Lembramos por isso, ter-se cautela na interpretação da composição química de um magma, quando baseada apenas no produto "seco" da súa cristalização.

As inúmeras ocorrências de ágatas, quartzo e zeolitas nas efusivas vesiculares do sul do Brasil são prova concreta de que o magma original era de fato mais rico em sílica e álcalis e talvez em alumina, do que o seu precipitado comum, o "basalto".

Acreditamos que para a massa principal dos derrames, a análise $n^{\circ} 13$, referente a um hialo-basalto rico em vidro, corresponde à mais próxima do magma original.

\section{MUDANÇAS PROVOCADAS PELO CONT ACTO DAS ROCHAS EFUSIVAS COM AS PREEXISTENTES.}

Exomorfismo. As rochas preexistentes, com as quais as efusivas entram em contacto são, comumente, arenitos "eólicos" da série São Bento. Sòmente diques e sills atravessam rochas de outra natureza, tais como calcáreos, folhelhos, tilitos e rochas cristalinas .

A influência dos derrames basálticos sobre os arenitos subjacentes é insignificante. Estes tornam-se mais resistentes e mais avermelhados, não se observando, contudo, qualquer recristalização ge-

- radora de quartzito ou formação de minerais novos. Na maioria das vezes, o chamado arenito cozido nada mais é do que um arenito secundàriamente silicificado por imbibição de sílica nos interstícios -silicificação intersticial. A silicificação teve lugar justamente no contacto. As alterações descritas por nós (24) de calcáreos e arenitos referem-se a contactos de diques com sedimentos.

Mesmo assim a silicificação intersticial limita-se a espessuras de poucos metros. Parece-nos que a temperatura e a reserva térmica da lava não eram suficientemente elevadas para refundir os arenitos 


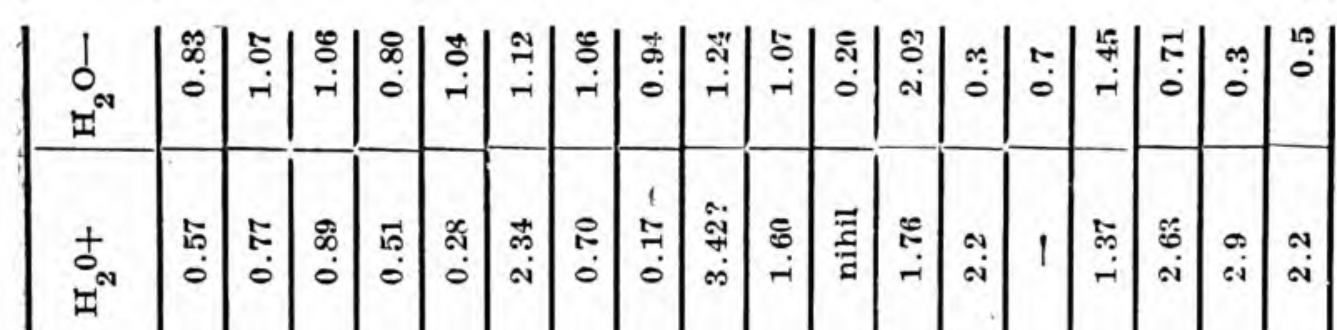

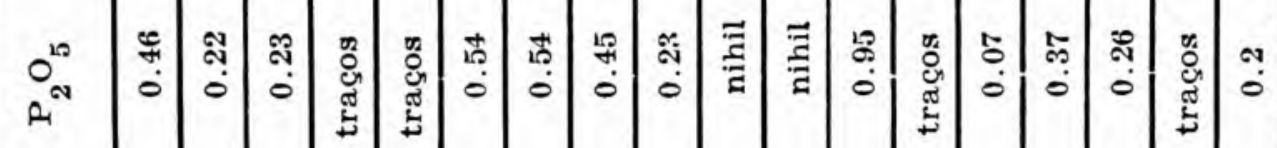

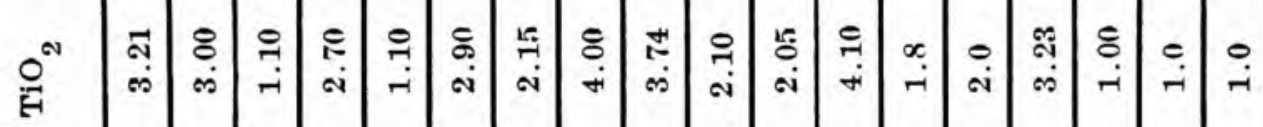

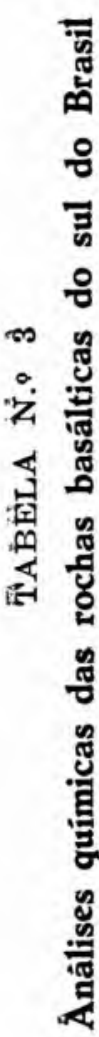

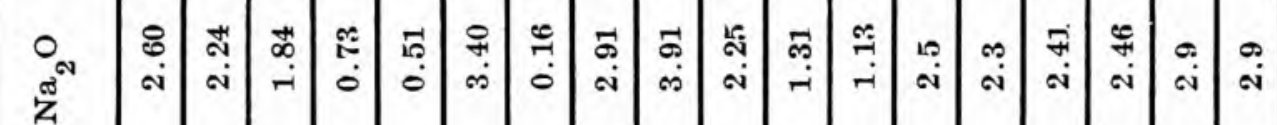

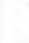

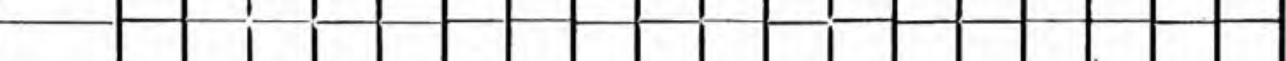

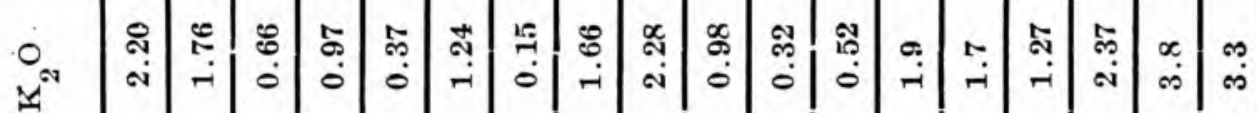

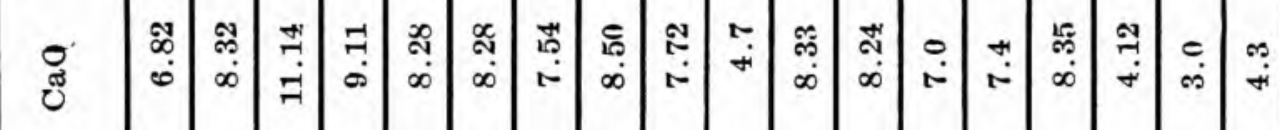

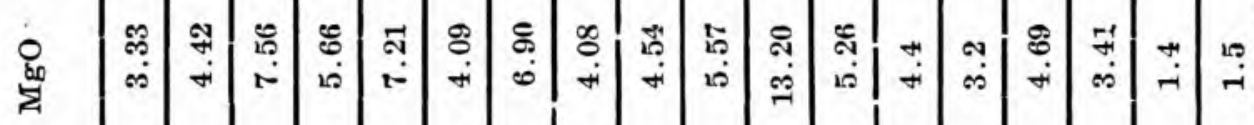

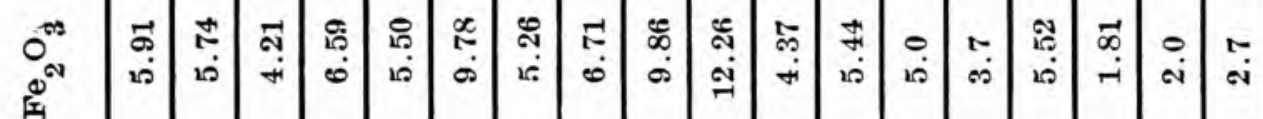

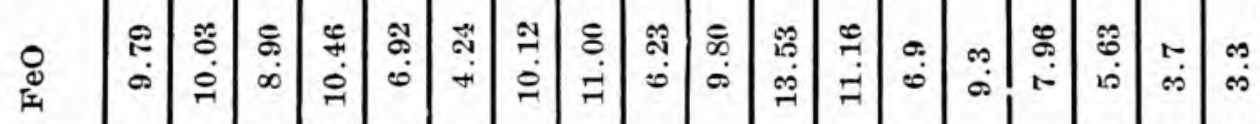

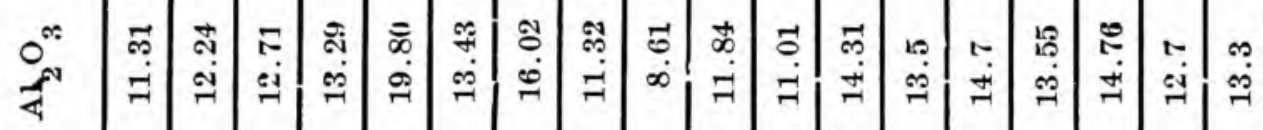

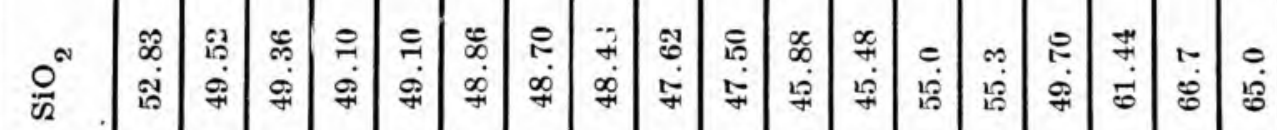

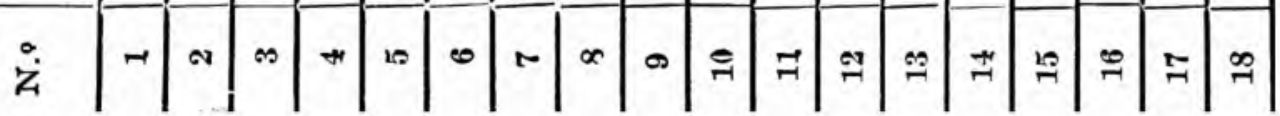


Procedência das análises químicas da Tabela $\mathbf{n}^{\circ} \mathbf{3}$

\begin{tabular}{|c|c|c|}
\hline N. ${ }^{\circ}$ & Localidade & Autor \\
\hline 1 - Diabásio & $\begin{array}{l}\text { Torres } \\
\text { Rio Gande do Sul }\end{array}$ & D. Guimarães (12) \\
\hline 2-Basaltito & $\begin{array}{l}\text { Rio Passo do Retiro } \\
\text { Paraná }\end{array}$ & D. Guimarães (12) \\
\hline 3- Basalto & $\begin{array}{l}\text { São João } \\
\text { Santa Catarina }\end{array}$ & D. Guimarães (12) \\
\hline 4-Basaltito & $\begin{array}{l}\text { Arroio Guassú - 1. Salto } \\
\text { Paraná }\end{array}$ & Leinz-Fontoura-Gomes (25) \\
\hline 5 - Porfirito & $\begin{array}{l}\text { Serra Esperança } \\
\text { Paraná }\end{array}$ & Leinz-Fontoura-Gomes (25) \\
\hline 6-Meláfiro & $\begin{array}{l}\text { Foz do Iguassu } \\
\text { Paraná }\end{array}$ & Leinz-Fontoura-Gomes (25) \\
\hline 7 -Diabásio & $\begin{array}{l}\text { Ponta Grossa } \\
\text { Paraná }\end{array}$ & Leinz-Fontoura-Gomes (25) \\
\hline 8 - Basaltito & $\begin{array}{l}\text { Rio Jaboticabal } \\
\text { São Paulo }\end{array}$ & D. Guimarães (12) \\
\hline 9 - Diabásio & $\begin{array}{l}\text { Salto de Guaira - Sete Quedas } \\
\text { Paraná }\end{array}$ & D. Guimarães (12) \\
\hline 10 - Diabásío & $\begin{array}{l}\text { Irati } \\
\text { Paraná }\end{array}$ & Leinz-Fontoura-Gomes (25) \\
\hline 11 - Diabásio & $\begin{array}{l}\text { Monte Alegre } \\
\text { Paraná }\end{array}$ & Leinz-Fontoura-Gomes (25) \\
\hline 12 - Diabásio & $\begin{array}{l}\text { Porto Martins } \\
\text { São Paulo }\end{array}$ & Leinz-Fontoura-Gomes (25) \\
\hline $\begin{array}{l}\text { 13-Hialo- } \\
\text { Basalto }\end{array}$ & $\begin{array}{l}\text { Três Forquilhas - altitude } 450 \mathrm{~m} \\
\text { Rio Grande do Sul }\end{array}$ & Anal: A. Espinola \\
\hline 14 - Basalto & $\begin{array}{l}\text { Três Forquilhas - altitude } 200 \mathrm{~m} \\
\text { Rio Grande do Sul }\end{array}$ & Anal: A. Espinola \\
\hline 15 - Basaltos & $\begin{array}{l}\text { (média de } 5 \text { análises proc. do Est. } \\
\text { de Mato Grosso e Terr. de Pon- } \\
\text { ta Porã) }\end{array}$ & Almeida (1) \\
\hline 16 - Basaltito & $\begin{array}{l}\text { Curral das Pedras } \\
\text { Rio Grande do Sul }\end{array}$ & D. Guimarães (12) \\
\hline $\begin{array}{l}\text { 17. Leidleito } \\
\text { (Hialo- } \\
\text { Dacito) }\end{array}$ & $\begin{array}{l}\text { Três Forquilhas - altitude } 700 \mathrm{~m} \\
\text { Rio Grande do Sul }\end{array}$ & Anal: A. Espinola \\
\hline $\begin{array}{l}18 \text { - Leidleito } \\
\text { (Hialo- } \\
\text { Dacito) }\end{array}$ & $\begin{array}{l}\text { Faxinal-Tainhas - altitude } 1.000 \mathrm{~m} \\
\text { Rio Grande do Sul }\end{array}$ & Anal: A. Espinola \\
\hline
\end{tabular}


TABELA N.9 4

\begin{tabular}{|c|c|c|c|c|c|c|}
\hline & Mínimo (1) & Máximo (2) & Médio (3) & Deccan (4) & Africa S. (5) & Kilauea (6) \\
\hline $\mathrm{SiO}_{2} \ldots \ldots \ldots$ & 46,60 & 55,3 & 49,1 & 50,61 & 50,75 & 50,32 \\
\hline $\mathrm{Al}_{2} \mathrm{O}_{3} \quad \cdots$ & 8,61 & 19,80 & 13,2 & 13,58 & 13,80 & 12,83 \\
\hline $\begin{array}{lll}\mathrm{FeO} & \ldots & .\end{array}$ & 4,24 & 13,53 & 9,2 & 9,92 & 6,20 & 9,93 \\
\hline $\mathrm{Fe}_{2} \mathrm{O}_{3} \quad \ldots$ & 3.7 & 12,26 & 6,6 & 3,19 & 4,65 & 1,74 \\
\hline $\mathrm{MgO} \quad \ldots \ldots$ & 3,2 & 13,20 & 6,6 & 5,46 & 7,10 & 7,39 \\
\hline $\mathrm{CaO} \quad \ldots .$. & 4,71 & 11,14 & 8,0 & 9,45 & 8,90 & 11,06 \\
\hline $\mathrm{K}_{2} \mathrm{O} \quad \ldots \ldots$ & 0,15 & 2,28 & 1,1 & 0,72 & 0,85 & 0,41 \\
\hline $\mathrm{Na}_{2} \mathrm{O} \quad \ldots \ldots$ & 0,16 & 3,91 & 2,0 & 2,60 & 2,85 & 2,38 \\
\hline $\mathrm{TiO}_{2} \quad \cdots$ & 1,10 & 4,10 & 2,5 & 1.91 & 1,15 & 3,10 \\
\hline $\begin{array}{lll}\mathrm{P}_{2} \mathrm{O}_{5} & \cdots \cdots\end{array}$ & traços & 0,95 & 0,3 & 0,39 & 0,20 & 0,30 \\
\hline $\mathrm{H}_{2} \mathrm{O}+$ & $?$ & $?$ & $?$ & 1,70 & 2,35 & 0,33 \\
\hline $\mathrm{H}_{2} \mathrm{O}-$ & 0,20 & 1,24 & 0,7 & 0,43 & 1,85 & 0,05 \\
\hline
\end{tabular}

Valores de Niggli

\begin{tabular}{c|c|c|c|c}
\hline $\mathrm{si}$ & 3 & 4 & 5 & 6 \\
\hline $\mathrm{al}$ & 118 & 126 & 126 & 118 \\
\hline $\mathrm{fm}$ & 54,5 & 47,5 & 48,0 & 48,5 \\
\hline $\mathrm{c}$ & 20,5 & 25,0 & 24,0 & 28,0 \\
\hline $\mathrm{alk}$ & 6,5 & 7,5 & 8 & 6,0 \\
\hline $\mathrm{ti}$ & 4,6 & 3,6 & 2,1 & 5,4 \\
\hline $\mathrm{mg}$ & 0,43 & 0,43 & 0,55 & 0,53 \\
\hline $\mathrm{k}$ & 0,26 & 0,15 & 0,16 & 0,10 \\
\hline $\mathrm{qz}$ & -8 & -4 & -8 & -6 \\
\hline
\end{tabular}

1. Valores minimos de 15 análises de basaltos brasileiros.

2. Valores máximos de 15 análises de basaltos brasileiros.

3. Valores médios de 15 análises de basaltos brasileiros.

4. Basalto do Deccan - India seg. D. Wadia (43) .

5. Basalto Zuurberg, Cape - Africa do Sul seg. A. L. Du Toit (9).

6. Basalto, tipo seg. Tröger (42) Mauna Iki Kilauea-Hawaii. 
constituidos exclusivamente de quartzo. As reservas térmicas dos derrames eram insuficientes para metamorfisarem esse embasamento refractário, principalmente considerando-se ainda o poder diatérmico das zonas vítreas e vesiculares dos derrames.

Fenômenos semelhantes ocorreram com os arenitos intra-efusivos. Também estes não sofreram metamorfismo térmico perceptivel, mas tão sòmente uma silicificação intersticial, - onde a ação hidro $e$ epitermal da lava - segundo o autor (26) foi mais acentuada.

Quanto aos efeitos do metamorfismo de contacto dos diques e sills já tratámos nas páginas $22,23$.

Endomorfismo. Raros são os fenômenos de endomorfismo observados. Hussak (19) descreve pormenorizadamente a formação de uma zona de contacto no basalto, rica em cordierita. Esta teria provindo do embasamento arenítico. Este autor não precisa a espessura dessa zona mas, pela descrição, infere-se que ela possui apenas poucos centímetros.

Achamos no "Salto", Canela, R. G. S., nas obras de barragem, uma amostra interessante indicando a insignificância tanto do endomorfismo como do exomorfismo. Trata-se de um xenolito anguloso de granito de cerca de $20 \mathrm{~cm}$ de diâmetro incluso no basalto. Sendo a espessura local do basalto quase 1.000 metros, deve-se encontrar o embasamento cristalino pelo menos a 1.500-2 .000 metros de profundidade, de onde proveio verossimilmente aquela inclusão de granito. Este xenolito, por outro lado, poderia ter tido origem em um fragmento de seixo glacial, cuja rocha matriz se encontra pràticamente a essa mesma profundidade. Pois bem, esse bloco de densidade 2,6 , nadando consequentemente na lava de densidade 2,8 , sofreu pouca influência durante seu percurso.

O granito é granular e compõe-se de plagioclásio com $30 \%$ An, quartzo, ortoclásio e pouca mica. A granulação média oscila de $2-5 \mathrm{~mm}$.

A auréola de contacto no granito é perceptível apenas numa espessura de 1 centímetro. Nessa auréola de reação, observa-se o seguinte: $\mathrm{O}$ plagioclásio, possuindo geminação fina, segundo a lei da albita, se dissolve em forma celular, segundo as duas clivagens principais. O esqueleto das "células" consiste de um vidro claro, ligeiramente castanho, com índice ${ }^{ \pm 1,52}$, enquanto que $o$ núcleo continua a ser de plagioclásio. O ortoclásio sofreu o mesmo fenômeno, ao passo que o quartzo exibe apenas extinção ondulante muito nítida, provocada provàvelmente por tensões internas devido ao aumento brusco da temperatura. (Fot. 9).

O basalto envolvente mostra apenas uma zona vítrea de contacto, coloração castanha mais clara do que o vidro comum à rocha e ausência de quaisquer fenocristais.

A auréola vítrea possui cerca de 2 centímetros de espessura. Deduzimos desses fatos o seguinte: o granito não permaneceu estável no magma e sofreu fusão ao ser assimilado, mas a duração da reação foi insignificante. A assimilação foi ainda dificultada pela 
formação de uma película vítrea protectora, que envolveu a inclusão. Essa película vítrea possui, provàvelmente, composição química intermediária caracterizada pelo índice 1,52, mais baixo do que o comum, 1,56.

Podemos deduzir, também, que a subida do magma se realizou tão ràpidamente que não houve tempo para a assimilação. Desta forma, naturalmente devemos procurar qualquer assimilação do magma no foco profundo e não no percurso da sua ascensão.

Este fato leva-nos a admitir que a ausência atual, quase absoluta, de xenolitos nas efusivas, é primária e não oriunda de uma digestão completa. O magma, tendo encontrado na ascenção caminho desimpedido, - as fendas, - não sofreu atividade explosiva.

\section{TECTÔNICA A}

O estudo tectônico de tão vasta área é dificultado pela extensão, pela escassez de afloramentos accessíveis e pela cobertura relativamente homogênea formada pelas efusivas. Tentando um esclarecimento das grandes linhas tectônicas, nós usaremos as seguintes observações: posição e superfície do embasamento das efusivas; direção e inclinação dos sedimentos pré-efusivos, suas diaclases e falhas; direção provável da corrida da lava; diaclases das efusivas, e finalmente, a diferença litológica dos sedimentos glaciais.

\section{MOVIMENTOS ANTERIORES E SIMULTÂNEOS AO VULCANISMO}

\section{POSIÇÃO E SUPERFICIE DO EMBASAMENTO DAS EFUSIVAS (Fig. 2)}

O embasamento dos derrames em todo o sul do Brasil é constituido pelos bancos espessos e horizontais do arenito triássico Botucatú. Sua litologia é bem homogênea em toda a área, possuindo estratificação cruzada pronunciada. A inclinação dos estratos cruzados vai de $25^{\circ}$ a $30^{\circ}$ Não discutiremos aqui a direção da sedimentação.

A superfície arenítica na época do derrame era, em geral, pràticamente plana. Pequenas irregularidades topográficas de poucos metros são comuns; raras vezes são de vulto. Assim, no Morro Pelado (Sta. Catarina), a superfície do arenito acusa uma elevação pré-efusiva de-cerca-de 120 metros sobre a planície comum. Também em Sta. Maria (R. G. S.), observa-se, como já descreveu Gordon (11), que todo pacote de arenito de-cerca-de 150 metros de espessura foi erodido até às camadas Sta. Maria, com transbordamento da lava sobre essas camadas. A erosão do Botucatú perto de Sta. Maria, (R. G. S.), operou numa zona de movimentos tectônicos como veremos nas páginas 44,45 . 
Vários fenômenos indicam que o arenito Botucatú já estava diaǵenèticamente consolidado na época em que se deu o derrame vulcânico. Assim encontram-se, às vezes, "xenolitos" de arenito Botucatú inclusos na lava. Comprova ainda esta consolidação a ausência de "areias" envolvidas pela primeira corrida da lava, e também a ausência de perturbações locais, que deveriam ser provocadas pela lava correndo sobre um fundo arenoso. Finalmente a ausência de diques arenosos ascendentes na base, confirma a consolidação anterior do arenito.

Sem dúvida houve sedimentação eólica durante a efusão, no mesmo estilo da prévia sedimentação do arenito. Mas os sedimentos arenosos intra-efusivos não estavam consolidados, o que deu lugar assim a inúmeras inclusões e "Schlieren" arenosas nas efusivas superiores, bem como aos diques de areia ascendentes descritos por Washburne (46) .* Resumindo, diremos que hove um hiato da sedimentação do Botucatú antes do vulcanismo, com reativação da sedimentação durante o vulcanismo. $x$

Assim a posição do arenito do embasamento, verificada parte por nivelamento e parte por determinação barométrica, encontra-se na tabela n. $^{\circ}$ 1. O contacto arenito-efusiva possui sua posição, a mais baixa, quase ao nível do mar, na região Torres-Três Forquilhas, justamente no lugar de maior espessura das lavas, subindo lentamente rumo sul até S. Antonio (R. G. S.) com cerca de 100 metros de altitude em 70 quilômetros de distância. Aqui, a escarpa inflete rumo oeste acompanhada, também, por uma ascensão contínua do embasamento, que de 100 metros atinge seu valor máximo de 270 metros sobre o nível do mar em Sta. Maria. Observa-se, assim, uma subida de 170 metros em cerca de 300 quilômetros de distância ou cerca de 60 centímetros por quilômetro. Continuando rumo oeste o contacto desce então até Jaguarí a 120 metros, o ponto mais ocidental observável no Rio Grande do Sul. Temos pois, de Sta. Maria a Jaguarí uma queda de 150 metros de altitude em cerca de 100 quilômetros de distância.

Do ponto mais baixo, próximo a Torres, seguindo-se em direção norte, observa-se subida brusca do contacto, acompanhada por falhamento escalonar. Em Araranguá, o topo do embasamento já se acha a cerca de $\mathbf{3 5 0}$ metros de altitude numa distância de $\mathbf{5 0}$ quilômetros a partir de Torres. Sobe ainda, ràpidamente, rumo norte, até Cresciuma, onde atinge o nível de 650 metros, isto é, alcança 600 metros em cerca de 100 quilômetros. A ascensão do contacto prossegue ainda, rumo norte, até um ponto culminante perto de Lages, com 980 metros. Daqui para o norte, inicia-se ligeira descida rumo Paraná-São Paulo, naturalmente considerandose sempre as observações na orla oriental dos derrames.

O contacto entre o embasamento arenítico e a lava é, via de regra, horizontal ou quase horizontal. A lava quase não afetou tèrmicamente o embasamento, como também não exerceu qualquer 
efeito erosivo ou perturbador sobre a superfície do embasamento, ou em outros termos, a lava deslisou.

Bem diferente é o comportamento do contacto entre a lava e os arenitos intercalados.

Observa-se frequentemente, nas lavas superiores, intercalações de sedimentos arenosos. Isto se dá principalmente na região $\mathrm{S}$. Anglo-Ijuí (R. G. S. ), na região de Guarapuava no Paraná, e em Botucatú e São Carlos no Estado de S. Paulo. Esses depósitos arenosos assentam-se sobre $\circ$ basalto vesicular com superfície irregular, cavernosa e em forma de crosta. Sua espessura varia muito, desde centímetros até 16 metros, máximo este, observado por sondagem na região de Catanduva (S. Paulo). O derrame posterior atin. giu intensamente estes sedimentos. Parte destes sedimentos arenosos-argilosos ainda não consolidados, foi envolvida e transportada pela lava, apresentando-se hoje sob a forma de "Schlieren", veios e vênulas irregulares no basalto. Forma, também, "diques" de arenito ascendentes no basalto descritos por Washburne (46) no Estado de S. Paulo, e também frequente na região de Iraí, Ijuí, S. Angelo, S. Luiz (R. G. S.).

\section{DIREÇÃO E INCLINAÇÃO DOS SEDIMENTOS PRE-EFUSIVOS}

Sòmente em poucos casos foi possível tomar diretamente estes dados: quando havia um afloramento de relativa extensão e uma camada guia visível. Devido ao ângulo insignificante, sòmente com o auxílio do nível de precisão poude se chegar a um valor razoável. Assim, obtivemos no vale Santa Maria em Taquara (R. G. S.), por nivelamento de 3 pontos de uma camada argilosa no arenito Botocatú, uma direção de $\mathrm{N}^{\circ} \mathrm{O}^{\circ} \mathrm{W}$ com declive para o norte de 10 metros por quilômetro. No rio Jacuí, em Sobradinho (R. G. S. ), também no arenito Botucatú, a direção é $\mathrm{N} 80^{\circ} \mathrm{W}$ e o declive para o norte é de 6 metros por quilômetro. No Morro do Convento, em Araranguá (S. C.) as camadas do Estrada Nova (Rio do Rasto?) possuem direção $\mathrm{N} 60^{\circ} \mathrm{W}$ com 10 metros por quilômetro de mergulho, para o sul.

São poucas, assim, as observações diretas, apresentando mergulhos de pequeno valor, mas concordantes quanto ao sentido deste mergulho com as deduções estratigráficas. As camadas gondwânicas do sul devem forçosamente mergulhar para oeste, para norte e para sul, conforme está indicado na fig. 17, sendo discutível apenas o grau do mergulho. Se o valor mínimo achado de 6 metros por quilômetro fôr verdadeiro, e parece-nos que é, teremos então que aceitar perturbações consideráveis no embasamento.

Na linha Osorio-Torres (R. G. S.), perfil aproximadamente paralelo ao mergulho, o arenito Botucatú mergulha de fato $150 \mathrm{me}-$ tros em 100 quilômetros de extensão ou seja 1,5 metros por quilômetro. A divergência achada, entre 6-10 metros e 1,5 metros pare- 
ce-nos ùnicamente explicável por falhamento compensado do mergulho regional dos pacotes sedimentares.

Independentemente dessas perturbações a fig. 17 mostra claramente a convergência dos mergulhos para uma linha aproximadamente E-W, cujo máximo é atingido perto de Torres (R. G. S.).

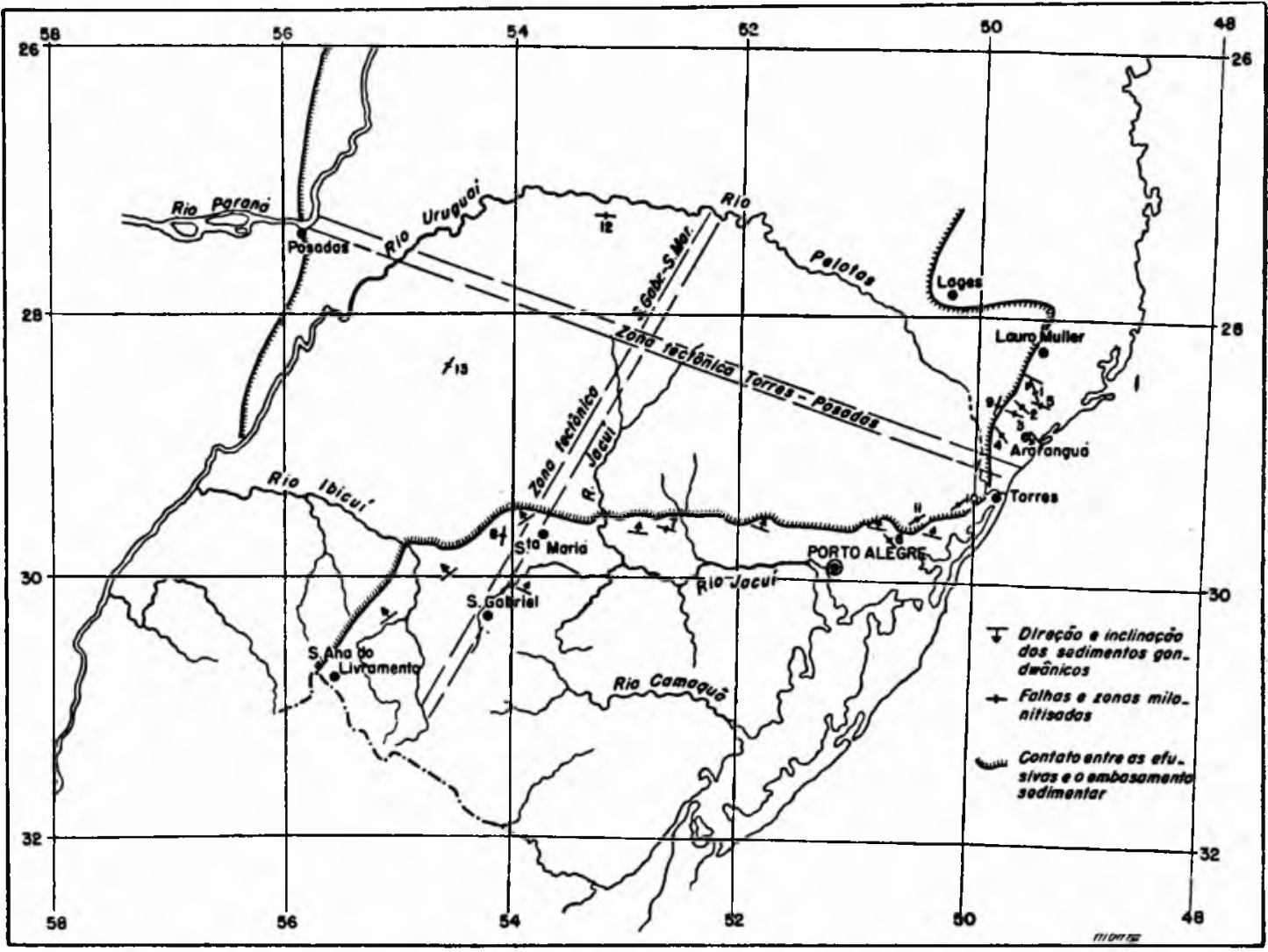

Fig. 17 - Mapa tectônico indicando direções e inclinações nos sedimentos. gondwânicos, falhas e zonas de milonitização

Observa-se por outro lado mudança brusca da direção, bem como da inclinação das camadas gondwânicas, para o lado oeste do Rio Grande do Sul, cujo eixo se acha perto de Santa Maria. A leste desta cidade as camadas possuem ainda direção E-W com mergulho para norte. Já 10 quilômetros para oeste da mesma cidade todas as camadas mergulham rumo oeste. A linha de inversão segue mais ou menos o rumo $\mathrm{N} 30^{\circ} \mathrm{E}$, tocando $\mathrm{S}$. Gabriel e Sta. Maria (R. G. S.)

\section{FALHAS, ZONAS DE MILONITIZAÇÃO E DIACLASES}

Poucas são as possibilidades de observação direta de falhas, - devido à falta de afloramentos. A verificação de deslocamentos nos derrames é dificultada, ainda, pela falta de camadas guias. Mesmo assim, foi possível verificar a existência de várias falhas importantes no embasamento sedimentar $\mathrm{Na}$ literatura encontram-se alguns dados sobre falhamentos do embasamento. Gordon (11) cita. 
uma falha com rejeito de 95 metros no município de Bom Retiro (S. C.), atingindo o arenito Botucatú e possivelmente também a parte basal do derrame. Infelizmente não há pormenores sobre a direção, etc. No município de Araranguá (S. C.) foram encontrados dois tipos de deslocamentos. O primeiro refere-se a um falhamento que interessou apenas o arenito Botucatú, com preenchimento do degrau falhado pela lava, indicando assim, que o derrame se realizou imediatamente após o falhamento. O outro é constituído de uma falha quase vertical, com alargamento da fratura e seu preenchimento por um dique com 80 metros de possança que emboca no derrame basal.

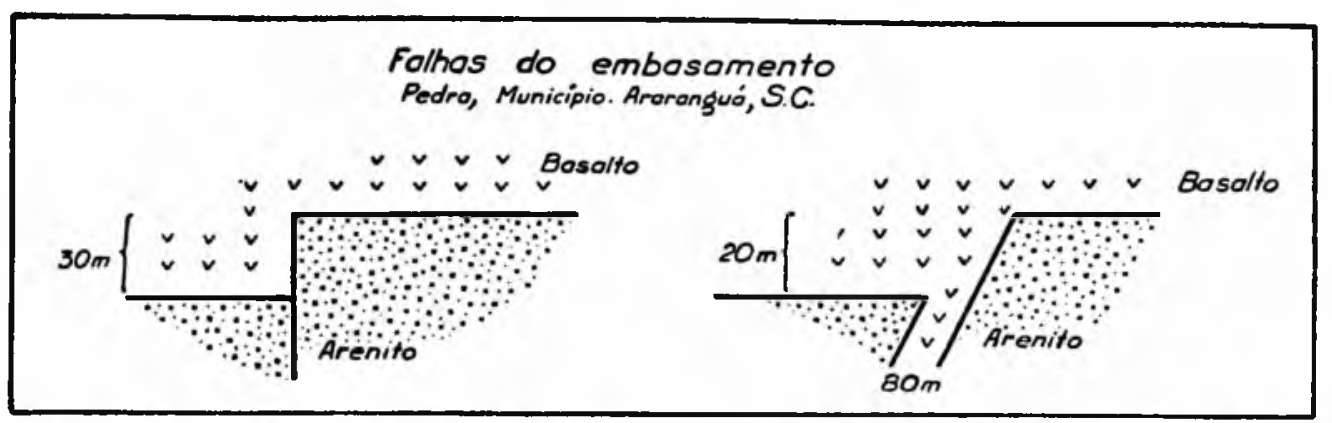

Fig. 18 - Esquema de falhas no arenito Botucatú; Araranguá, Santa Catarina

A verificação de movimentos tectônicos nos derrames é sòmente possível por zonas de esmagamento atravessando as efusivas. $O$ basalto afetado por movimentos fratura-se e mostra uma brecha de atrito passando a milonito. A decomposição ataca com intensidade tais zonas, mas entretanto, elas não permitem a verificação do sentido do deslocamento e nem o seu rejeito. A possança das zonas de trituração é de poucos metros, mas atravessa todos os derrames observáveis .

$$
* * *
$$

Todas as falhas observadas foram normais; em nenhum dos casos foi encontrado um espelho de fricção indicador do sentido de levantamento ou abaixamento dos blocos.

Na tabela n. ${ }^{\circ} 5$ e na fig. 17 damos os resultados das observações feitas. Destacam-se nitidamente 2 sistemas. O primeiro possui rumo do plano da falha entre $\mathrm{N} 50^{\circ} \mathrm{W}$ e E-W Esta direção parece-nos a mais importante para a região estudada. Aliás, Maack (29) fala da importância dos falhamentos entre $\mathrm{N} 70^{\circ} \mathrm{W}$ e $\mathrm{N} 50^{\circ} \mathrm{W}$ na área em questão, dando desníveis de 40 até 300 metros, porém parece-nos difícil observar diretamente na região falhas com rejeitos tão consideráveis. Esse autor, entretanto, não faz referência como e onde foram observados desníveis estratigráficos dessa envergadura.

O outro sistema de perturbações segue o rumo dos antigos "Brasilides", isto é, cerca de $\mathrm{N}^{\circ} 0^{\circ}-40^{\circ} \mathrm{E}$. O número de observações, entretanto, não é suficiente para a conclusão da direção predomi- 
nante. As duas direções, porém, atingiram não só o embasamento como também as efusivas. Parece-nos provável, contudo, que a maior intensidade dos movimentos verticais ou quase verticais se tenha manifestado antes ou, talvez em parte, durante as atividades vulcânicas. Os movimentos posteriores representam rejuvenescimento de menor intensidade, segundo linhas pré-estabelecidas. A ocorrência de um elevado número de diques sem falhamento constituem prova que existiram também movimentos laterais, que causaram a abertura de fendas, preenchidas posteriormente pelo magma.

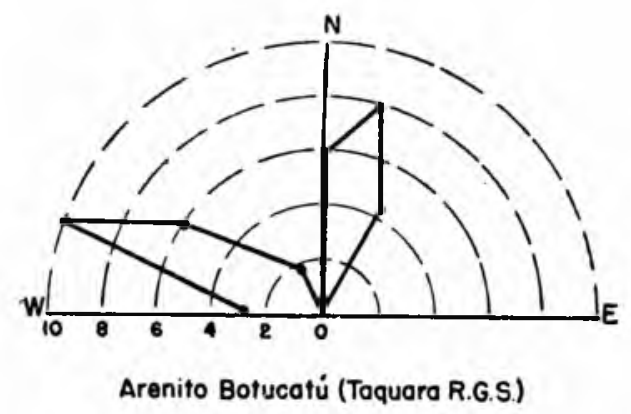

Fig. 19 - Direções de diaclase no arenito Botucatú; Taquára, Rio Grande do Sul.

Diaclase - $\mathrm{O}$ estudo das diaclases abrangeu as rochas areníticas do Botucatú bem como os derrames.

No arenito encontramos nitidamente desenvolvidos dois sistemas de diaclases. A frequência é relativamente espaçada. Numa distância horizontal de 10 metros - em corte recente - ocorrem cerca de 3 diaclases perceptíveis. Diaclases latentes são muito fracamente desenvolvidas. Assim, o número das observações é limitado. O contrário ocorre nas efusivas basálticas. Aqui observam-se inúmeras juntas visíveis em pequeno espaço, com grande frequência das latentes. A maior parte foi produzida por contração durante o resfriamento. E difícil separar as diaclases de contração, das de tectônica, as únicas interessantes no nosso caso. Mas como há mudanças frequentíssimas das direções das diaclases de contração e como há persistência contínua de certas direções, tomámos as últimas como as representantes das tectônicas. Estas, aliás, atravessam frequentemente as de contração. Em todo caso, podemos eliminar todas as direções horizontais ou quase horizontais. Elas aumentam ou diminuem conforme a posição no derrame e são produzidas exclusivamente pela contração durante o resfriamento.

$\mathrm{O}$ número das juntas tectônicas é de muito maior frequência nas efusivas, encontrando-se frequentemente até 5 visíveis num metro linear Aliás, era lícito esperar que os movimentos tectônicos se manifestassem muito mais competentemente no material rígido dos basaltos do que nos arenitos. A intensidade de diaclasamento, mesmo nos basaltos competentes, indica que os movimentos tectônicos posteriores ao vulcanismo atingiram ainda certa importância.

Nas figs. 20a e 20b mostramos, em 2 exemplos, todas as diaclases observadas em derrames e a persistência de 2 direções indicadoras do tectonismo. 
E grande a persistênicia das direções das diaclases tectônicas; tanto no arenito Botucatú como nos derrames encontramos sempre valores semelhantes para os dois derrames. Oscilam em volta de $\mathrm{N} 60^{\circ} \mathrm{W}$ e $\mathrm{N} 15^{\circ} \mathrm{E}$ e possuem planos verticais.
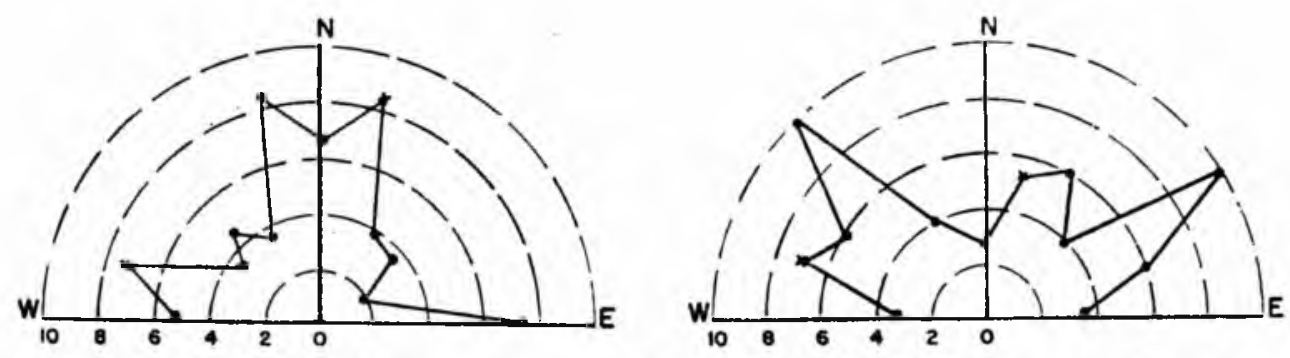

Figs. 20a 20b - Direções de diaclasamento tectônico e de contração no basalto.

Os pontos $\mathrm{X}$ indicam as diaclases persistentes (tectônicas).

Julgamos ser prematuro deduzir fenômenos tectônicos baseados em observações esparsas numa área tão vasta. Desejamos apenas ressaltar que tanto o embasamento, como principalmente as efusivas, sofreram ajustamentos tectônicos posteriores.

\section{A LINHA TECTÔNICA TORRES-POSADAS}

Os primeiros indícios de uma perturbação tectônica no rumo leste-oeste observamos no período Carbonífero (?) durante a formação dos sedimentos da série Itararé. Em nosso estudo sobre a formação dos sedimentos glaciais (23), chamámos atenção para a diferença entre os depósitos glaciais dos Estados do Rio Grande do Sul e Santa Catarina e os sedimentos das áreas mais setentrionais do norte de Santa Catarina, Paraná e São Paulo. No sul encontram-se apenas sedimentos "subglaciais", com a espessura de poucas dezenas de metros. Tilitos verdadeiros estão intercalados apenas como manchas locais. O relevo glacial da zona sul é, também, bem movimentado e variado, ao contrário do norte onde encontramos transgressões marinhas intercaladas e uma superfície glacial muito suave. Interpretámos tais diferenças de fácies do seguinte modo: durante as tempos glaciais o escudo riograndense, do qual fazia parte o sul de Santa Catarina, ocupava um nível topográfico relativamente elevado, predominando assim a erosão glacial, enquanto o norte ocupava uma posição baixa com sedimentação intensa acompanhada de invasões marinhas ocasionais. Na época da formação dos sedimentos "Iratî", (Permiano), observa-se um fácies muito extenso, idêntico no norte e no sul, que colocou por reajustamento as duas províncias no mesmo nível. Este reajustamento realizou-se, provàvelmente, segundo uma faixa tectônica TorresPosadas, situada na antiga divisa das duas províncias. Por enquanto 
TABELA N.9 5

\section{Falhas observadas}

\begin{tabular}{|c|c|c|c|c|}
\hline Localidade & Direção & Inclinação & Rejeito & $\begin{array}{c}\text { Formação } \\
\text { falhada }\end{array}$ \\
\hline $\begin{array}{l}1 \text { Cresciuma ............. } \\
\text { Santa Catarina }\end{array}$ & $\mathrm{N} 50^{\circ} \mathrm{W}$ & $80^{\circ} \mathrm{S}$ & $8 \mathrm{~m}$ & Tubarão \\
\hline $\begin{array}{l}2 \text { - Pedra-Araranguá } \ldots . . . \\
\text { Santa Catarina }\end{array}$ & $\mathrm{N} 50^{\circ} \mathrm{W}$ & $90^{\circ}$ & $+30 \mathrm{~m}$ & Botucatú \\
\hline $\begin{array}{l}\text { 2- Pedra-Araranguá } \ldots . . . \\
\text { Santa Catarina }\end{array}$ & $\mathrm{N} 70^{\circ} \mathrm{W}$ & $90^{\circ}$ & $25 \mathrm{~m}$ & Botucatú \\
\hline $\begin{array}{l}\text { 4- Arroio Leão-Araranguá } \\
\text { Santa Catarina }\end{array}$ & $\mathrm{N} 40^{\circ} \mathrm{E}$ & $70^{\circ} \mathrm{S}$ & $10 \mathrm{~m}$ & Botucatú \\
\hline $\begin{array}{l}\text { 5- Arroio Rato-Cresciuma } \\
\text { Santa Catarina }\end{array}$ & $\mathrm{N} 70^{\circ} \mathrm{W}$ & $90^{\circ}$ & $12 \mathrm{~m}$ & Botucatú \\
\hline $\begin{array}{c}6 \text { - Rio Sta. Maria-Taquara } \\
\text { Rio Grande do Sul }\end{array}$ & $\mathrm{N} 60^{\circ} \mathrm{W}$ & $70^{\circ} \mathrm{S}$ & $10 \mathrm{~m}$ & Botucatú \\
\hline $\begin{array}{l}7 \text { - Arroio Passa Sete-Can- } \\
\text { delaria } \ldots \ldots \ldots \ldots \ldots \ldots \\
\text { Rio Grande do Sul }\end{array}$ & $\mathrm{N} 80^{\circ} \mathrm{W}$ & $70^{\circ} \mathrm{S}$ & $8 \mathrm{~m}$ & Botucatú \\
\hline $\begin{array}{l}\text { 8- Mata-S. Vicente .... } \\
\text { Rio Grande do Sul }\end{array}$ & $\mathrm{N} 10^{\circ} \mathrm{E}$ & $90^{\circ}$ & $5 \mathrm{~m}$ & Botucatú \\
\hline $\begin{array}{l}\text { 9 - Pedra - Araranguá } \ldots . . . \\
\text { Santa Catarina }\end{array}$ & $\mathrm{N} 15^{\circ} \mathrm{E}$ & $80^{\circ} \mathrm{E}$ & $?$ & Derrame \\
\hline $\begin{array}{l}10 \text { - Arroio Carvalho - Três } \\
\text { Forquilhas } \ldots \ldots \ldots \ldots \\
\text { Rio Grande do Sul }\end{array}$ & N30도 & $90^{\circ}$ & $?$ & Derrame \\
\hline $\begin{array}{l}11 \text { Salto Canela } \ldots . . . \\
\text { Rio Grande do sul }\end{array}$ & $\mathrm{N} 80^{\circ} \mathrm{W}$ & $70^{\circ} \mathrm{S}$ & $?$ & Derrame \\
\hline $\begin{array}{l}12 \text { Prado Iraí } \ldots \ldots \ldots \ldots \\
\text { Rio Grande do Sul }\end{array}$ & E W & $90^{\circ}$ & $?$ & Derrame \\
\hline $\begin{array}{c}13 \text { - Guaramano - S. Luiz .. } \\
\text { Rio Grande do Sul }\end{array}$ & $\mathrm{N} 30^{\circ} \mathrm{E}$ & $90^{\circ}$ & $?$ & Derrame \\
\hline
\end{tabular}


não possuimos elementos para esclarecer sob que forma se realizaram esses movimentos. G. de Paiva (35) pronunciou-se igualmente de modo categórico sobre a existência de duas províncias, colocando sua divisão na zona de Lages-Anitápolis.

Também no Triássico, durante a formação dos arenitos Botucatú, as duas províncias estiveram unidas. Não se observa qualquer variação de fácies litológico nesses sedimentos, nas áreas norte e sul.

Mas, na época imediatamente anterior e durante as atividades magmáticas, efetuaram-se perturbações tectônicas consideráveis na faixa "móvel" $O$ embasamento sedimentar é frequentemente falhado e com grande intensidade. $\mathrm{Na}$ faixa Cresciuma-Araranguá, numa distância de-cerca-de 40 quilômetros, verificamos 5 falhas, enquanto que em várias centenas de quilômetros para sul e oeste no Rio Grande do Sul conseguimos localizar apenas 3 falhas. A direção predominante é cerca-de $\mathrm{N}^{\circ} 0^{\circ} \mathrm{W}$ Observa-se também grande número de diques, em parte de espessuras consideráveis, possuindo rumo semelhante ao das falhas citadas.

Depois e talvez durante o vulcanismo esta zona fraca serviu de "dobradiça" dos movimentos tectônicos, talvez isostáticos, que inclinaram o embasamento sedimentar no sentido convergente ao dessa faixa tectônica.

As zonas milonitizadas dos basaltos seguem, igualmente, em 3 para 5 casos observados, o mesmo rumo, o que indica que movimentos posteriores obedeceram ainda a mesma direção. Tudo indica se tratar de uma faixa tectônica muito antiga, seguidamente rejuvenescida, com um rumo em torno de $\mathrm{N} 50^{\circ}-70^{\circ} \mathrm{W}$. Designamos esta linha tectônica Torres-Posadas e ainda hoje parece que se prolonga no oceano Atlântico. Pelos levantamentos topográficos da expedição "Meteor", do fundo do Atlântico sul ressalta o lombc submarino denominado riagrandense. Este lombo submarino emerge de 5.000 metros de profundidade para atingir elevações máximas de $\mathbf{5 0 0}$ metros abaixo do nível do mar

O rumo deste lombo submarino é mais ou menos segundo WNW. Com esta localização, parece ser a continuação da faixa tectônica acima discutida (Fig. 21)

E justamente nessa faixa móvel que as efusivas possuem suas maiores espessuras, e ipso facto, constituem a sede de uma das maiores perturbações, onde foi permitida, assim, a ascensão de grandes massas magmáticas.

Concluindo, achamos que a melhor designação para tal faixa tectônica é a de Torres-Posadas. Tudo indica que a brusca inflexão do rio Paraná (perto de Posadas) do seu curso norte-sul para lesteoeste é motivada pelo seu encontro com a perturbação tectônica localizada na linha Torres-Posadas. Não possuimos, contudo, na literatura argentina dados suficientes para confirmar nossa hipótese. 


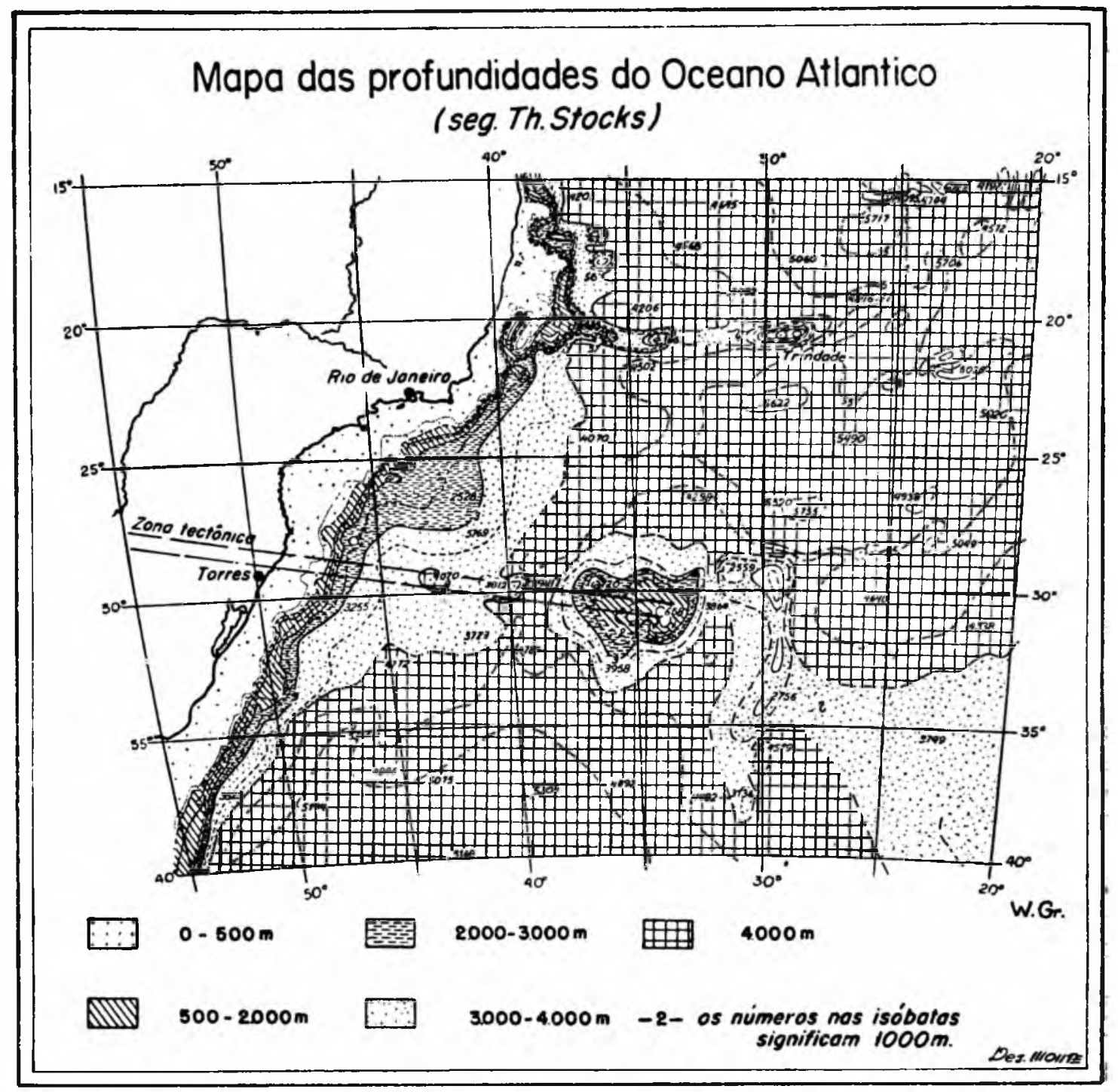

Fig. 21 - Mapa batimétrico do Oceano Atlântico segundo Stocks, indicando a linha tectônica Torres-Posadas e sua provável continuação no Atlântico.

\section{A LINHA TECTÔNICA S. GABRIEL-STA. MARIA}

Observando-se os níveis de contacto entre as efusivas e o embasamento sedimentar (Fig. 2) no Rio Grande do Sul, no sentido leste-oeste, nota-se uma ascensão lenta mas contínua do embasamento, pois de-cerca-de 60 metros sobre o nível do mar, em Osorio, chega-se à altitude máxima de 270 metros perto de Sta. Maria. Desta cidade, rumo oeste, abaixa-se novamente o nível do cuntacto para atingir a altitude de 120 metros, perto de Jaguarí.

Nas páginas 36-38 e na figura 17 ficou demonstrado que as camadas gondwânicas possuem um mergulho no sentido norte nas áreas a leste de Sta. Maria, enquanto que a oeste desta cidade se verifica uma mudança brusca do mergulho para oeste. Huene e Stahlecker (17) já chamaram a atenção para o fato. 
Tal mudança brusca do mergulho das camadas do embasamento, como também a ascensão da linha de contacto até Sta. Maria, e a sua descida daí para oeste, indicam claramente uma perturbação tectônica com rumo aproxidamente $\mathrm{N} 30^{\circ} \mathrm{E}$, isto é, paralela ao Rio Uruguai e à costa marítima .

A idade, a importância e o caráter dessa zona perturbada são ainda muito duvidosos, sendo bem possível que esta faixa estivesse presente durante a subida da lava. Assim Gordon (11) observou que justamente perto da cidade de Sta. Maria os arenitos Botucatú sofreram uma erosão pré-vulcânica considerável, moncante a cerca de 100 metros de espessura, até as camadas de Sta. Maria. As efusivas derramaram-se neste lugar sobre as camadas de Sta. Maria; e também as observações das texturas fluidais (Fig. 13) mostram nìtidamente 2 rumos diferentes a leste e oeste do prologamento da faixa. E possível, assim, que os movimentos se manifestassem anterior ou simultâneamente ao vulcanismo.

Esta faixa de menor resistência desempenhou papel de grande importância no ajustamento isostático provàvelmente na fase postefusiva .

\section{MOVIMENTOS TECTÔNICOS POST- VULCANICOS}

\section{MOVIMENTOS ISOSTÁTICOS}

Na tabela $n .^{\circ} 1$ e na fig. 2 fornecemos dados altimétricos da linha de contacto entre as efusivas e o embasamento sedimentar Nota-se que essa linha possui seu ponto mais baixo perto de Torres, e sobe contìnuamente rumo sul até Osorio. Daí, para oeste, prossegue a ascensão até Sta. Maria. Mais para oeste a linha desce de novo, enquanto para o sul se manifesta uma subida. C sentido do mergulho e da direção das camadas pré-efusivas acompanha a direção e a ascensão do mergulho do plano "hipotético" de contacto. Concomitantemente à elevação do plano, reduz-se a espessura das efusivas. O fenômeno é bem visível na fig. $n .^{\circ} 2$. Distinguem-se fàcilmente blocos diferentes na área efusiva do Rio Grande do Sul. O bloco limitado pela escarpa Sta. Maria-OsorioTorres e pelas linhas tectônicas Torres-Posadas e S. Gabriel-Sta. Maria, possui o vértice de mergulho máximo perto de Torres. O segundo bloco, ocidental, acha-se limitado pela linha tectônica $\mathrm{S}$. Gabriel-Sta. Maria, que continua até Santana do Livramento e provàvelmente pelo vale do Uruguai. $O$ vértice de mergulho máximo acha-se, provàvelmente, perto da intersecção do rio Uruguai com a linha tectônica Torres-Posadas. O terceiro bloco situa-se ao norte da linha Torres-Posadas e o seu mergulho se dá principalmente para sul-sudoeste. 
Parece que a causa do afundamento do embasamento se liga ìntimamente ao aumento da espessura dos derrames. Onde se encontra a maior espessura das efusivas, verifica-se também o maior afundamento do embasamento. Parece que a causa do ajustamento deve ser procurada nos movimentos isostáticos post-vulcânicos. A sobrecarga das efusivas do bloco oriental deve ser procurada ao norte da linha Torres-Posadas, onde se realiza o abaixamento, e a oeste, na continuação da linha S. Gabriel-Sta. Maria, onde se verifica um levantamento relativo.

Se esta pressuposição fôr exata, podemos imaginar um processo semelhante para o bloco ocidental, na área situada entre o rio Uruguai e a faixa tectônica S. Gabriel-Sta. Maria. Nesta faixa observamos que a linha de contacto baixa ràpidamente para o lado oeste e sobe para o sul. O comportamento da linha indica um abaixamento isostático rumo noroeste, partindo de Sta. Maria. Isso indica que as espessuras das efusivas devem aumentar novamente no rumo noroeste. Assim, deve-se admitir maiores espessuras de rochas vulcânicas na parte norte do rio Uruguai, no eixo do Paraná ao norte de Posadas e no vale do Uruguai em geral. De fato, nessa região Hausen (15) verificou espessuras superiores a $\mathbf{4 0 0}$ metros. Também perto do rio Uruguai, em Anapey (Uruguai), Lambert (22) cita 540 metros de espessura para as efusivas atravessadas por sondagens.

Para esse bloco deve existir uma articulação de basculamento tectônico muito importante na região do atual vale do Uruguai, seguindo aproximadamente o seu rumo.

Os movimentos isostáticos deveriam ter começado durante as atividades efusivas e terminado não muito depois da paralização da fase vulcânica, isto é, por volta do período Jurássico. Foram, também possivelmente, reativados em parte por efeitos erosivos. Cremos que o diaclasamento tectônico das efusivas deve ser relacionado ao ajuste isostático.

Falhamentos - Observações diretas de falhamentos posteriores são muito raras. Encontramos uma zona de esmagamento perto de Faxinal (Tainhas) com rumo $\mathrm{N} 30^{\circ} \mathrm{E}$. A lagôa dos Patos e a lagôa Mirim ocupam zonas fortemente falhadas seja sob a forma de "graben" ou apenas escalonamento, preenchidas posteriormente por sedimentos modernos (terciários?) como indicamos na página 49. A escarpa Torres-Osorio possui rios de extensão insignificante. O divisor d'água se acha localizado diretamente no bordo da escarpa. A penetração erosiva desses rios na escarpa, apesar do desnível de quase 1.000 metros, não atinge mais que 10 quilômetros, ao contrário do que acontece na escarpa Osorio-Sta. Maria, com a dissecação pronunciada da antiga escarpa. Tal juventude fluvial, a zona milonitizada e o falhamento comprovado na lagôa dos Patos, indicam que houve falhamento intenso no rumo $\mathrm{N} 30^{\circ} \mathrm{E}$, possivelmente de idade terciária, e que também afetou a área coberta 
pelas efusivas. Assim, cremos que a escarpa Osorio-Torres não é o término original das efusivas, e sim uma escarpa tectônica provocada por abaixamento do bloco oriental, coberto hoje pelo mar Estudos mais pormenorizados das lagôas dos Patos e Mirim, por meio de sondagens, indicarão o rejeito verdadeiro e a idade do falhamento. Tais falhamentos, semelhantes ao recôncavo da Bahia, são muito sugestivos para possíveis ocorrências de petróleo. Julgamos que uma pesquisa geofísica para estudo da tectônica e sedimentação das lagôas já mencionadas seria um interessante passo neste sentido.

\section{FORMAÇÃO DE ESCARPAS}

Um dos fenômenos mais impressionantes dos derrames basálticos é sua confinação, principalmente na sua orla oriental, em escarpas. No lado norte de Santa Catarina assumem desníveis de 200 a 300 metros. Já no sul de Santa Catarina e Rio Grande do Sul essa orla, no lado atlântico, atinge 1.000 metros. Perto de Osorio a linha de escarpamento inflecte-se para oeste, abatendo-se ràpidamente seus desníveis bruscos. Além de Santa Maria a escarpa desaparece suavemente. Limitaremos nossas considerações à parte de Torres para o sul até Santa Maria.

Duas opiniões opostas, baseadas principalmente em observações na parte norte foram até agora emitidas para a explicação da escarpa. A primeira explicação é a do falhamento escalonar dada por Siemiradzki (40) em 1898. Posteriormente, Woodworth (49) opoz-se a essa interpretação, atribuindo à escarpa exclusivamente a efeitos erosivos, opinião seguida por todos os pesquisadores posteriores. Tal interpretação baseia-se em parte na pressuposição de que os derrames basálticos tivessem sido represados na sua corrida por terras mais altas, possivelmente formadas pelo arenito Botucatú. Washburne (46) e Oppenhein (34) endossaram esse ponto de vista. Contudo, seria possível supor-se uma escarpa original formada exclusivamente por extravasamento magmático sucessivo, com superposição de derrames, cujo escorregamento fôsse limitado pela viscosidade e quantidade do magma.

Se os extravasamentos sucessivos possuiram o mesmo volume, o que é provável, as corridas superpostas confinaram-se todas aproximadamente no mesmo lugar, formando um pacote composto com términos mais ou menos abrutos. A erosão posterior teria apenas remodelado a escarpa original. Acreditamos que se pode fàcilmente explicar, assim, a escarpa Osorio-Sta.-Maria, com numerosos morros "testemunhos" hoje na sua frente. Estes morros isolados possuem, ainda hoje, normalmente, uma capa protetora de pequena espessura de efusivas, sobressaindo na paisagem pouco ondulada. Ainda hoje se encontram êsses testemunhos até 30 quilômetros afastados da escarpa principal, indicando que a linha de escarpamento original se extendia muito mais para o sul, até a região ocupada pelo baixo Jacuí. E possível que tenha havido um adelgaçamento da lava naquele sentido, embora não se possa comprova-lo. 
O beiral abruto da escarpa atlântica entre Osório e Torres deve ter-se originado de falhamento relativamente moderno e não representa a terminação original.

\section{DRENAGEM FLUVIAL DA ÁREA DO PLANALTO DO RIO GRANDE DO SUL (Fig. 22)}

Os 3 blocos atuados por movimentos isostáticos diferentes descritos nas páginas... são também caracterizados por bacias de drenagem. As linhas tectônicas são hoje representadas por divisores d'água. A faixa Torres-Posadas separa nitidamente a bacia do rio Pelotas do rio Jacuí, enquanto que a linha S. Gabriel-Sta. Maria é o divisor d'água entre a bacia do Jacuí e a do Uruguai. A drenagem da bacia do Jacuí corre no sentido oposto ao do mergulho do embasamento pré-efusivo, mas concordante à inclinação das soleiras do derrame, isto é, rumo sudoeste. Os rios Jacuí (na parte do planalto), Taquarí e Caí, possivelmente já existiriam quando o movimento isostático contrário se fez sentir

E interessante observar que esses rios correm em ângulo oblíquo e contrário ao sentido do baixo Jacuí. Aliás, morfològicamente falando, o baixo rio Jacuí nada mais é do que a continuação do rio Vacacaí, isto é, do eixo de drenagem este-oeste, já muito antigo, que corre acima dos sedimentos gondwânicos, entre a escarpa efusiva e o embasamento cristalino. O alto Jacuí é apenas um afluente do primitivo Vacacaí. Huene e Stahlecker (17) já chamaram a atenção para os ângulos anormais dos afluentes do planalto do baixo Jacuí. Tal fato pode ser explicado da maneira seguinte: o Jacuí primitivo, bem como a sua continuação no Vacacaí, possuiram originalmente uma direção oposta, isto é, este-oeste, dirigindo-se rumo ao rio Uruguai, provàvelmente em associação com o rio Ibicuí, que atravessa a continuação da depressão central. Os rios do planalto. cujo curso atual é sudoeste, poderiam confluir para ele normalmente. Com o abaixamento posterior da costa, por falhas, talvez no Terciário, ter-se-ia dado a inversão de todo o curso do rio Jacuí. $O$ abaixamento da costa, descendo muito a base de erosão para a parte leste do rio, forçou uma retomada de erosão intensa. A inversão realizou-se progressivamente, avançando para oeste com diminuição constante do volume de água e portanto da força erosiva do curso que ainda se dirigia para oeste. $O$ trabalho erosivo do lado oeste era muito mais difícil devido à necessidade de cortar as rochas efusivas, ao contrário do que se dava do lado leste, onde o rio corria sobre os sedimentos gondwânicos. A época da inversão do curso do rio Jacuí é incerta mas provàvelmente $o$ abaixamento da costa se realizou no Terciário. Os dados relativos a este abaixamento são poucos. Todavia, uma sondagem ainda hoje em andamento na lagôa Mirim, perto da cidade de Rio Grande, com 200 metros de profundidade, ainda não atingiu o embasamento cristalino e continua atravessando se- 
dimentos relativamente soltos de idade desconhecida. Também no rio Camaquã, Leinz (27) descreveu um abaixamento relativamente recente do embasamento cristalino de, no mínimo, 55 metros, provocado por falhas no sentido norte-sul. Tal abaixamento da costa, originando a lagôa dos Patos e a lagôa Mirim, refletiu também, mais para norte, afetando a escarpa Osorio-Torres.

Pela inversão do baixo Jacuí, correndo naturalmente em nível mais elevado do que hoje, os afluentes de ângulo oblíquo original no sentido oeste, encurvaram lentamente seu trecho próximo à embocadura rumo leste. Assim, esses rios subsidiários possuem hoje na parte baixa do seu curso uma inflecção muito forte de sudoeste para sudeste.

Aliás, os afluentes da costa atlântica, na escarpa Torres-Osorio, estão atualmente numa fase semelhante. Todos tendem a capturar os afluentes do Jacuí. Assim, o arroio Carvalho, afluente direto do Atlântico, está em vias de capturar o rio "Tainhas", formador do

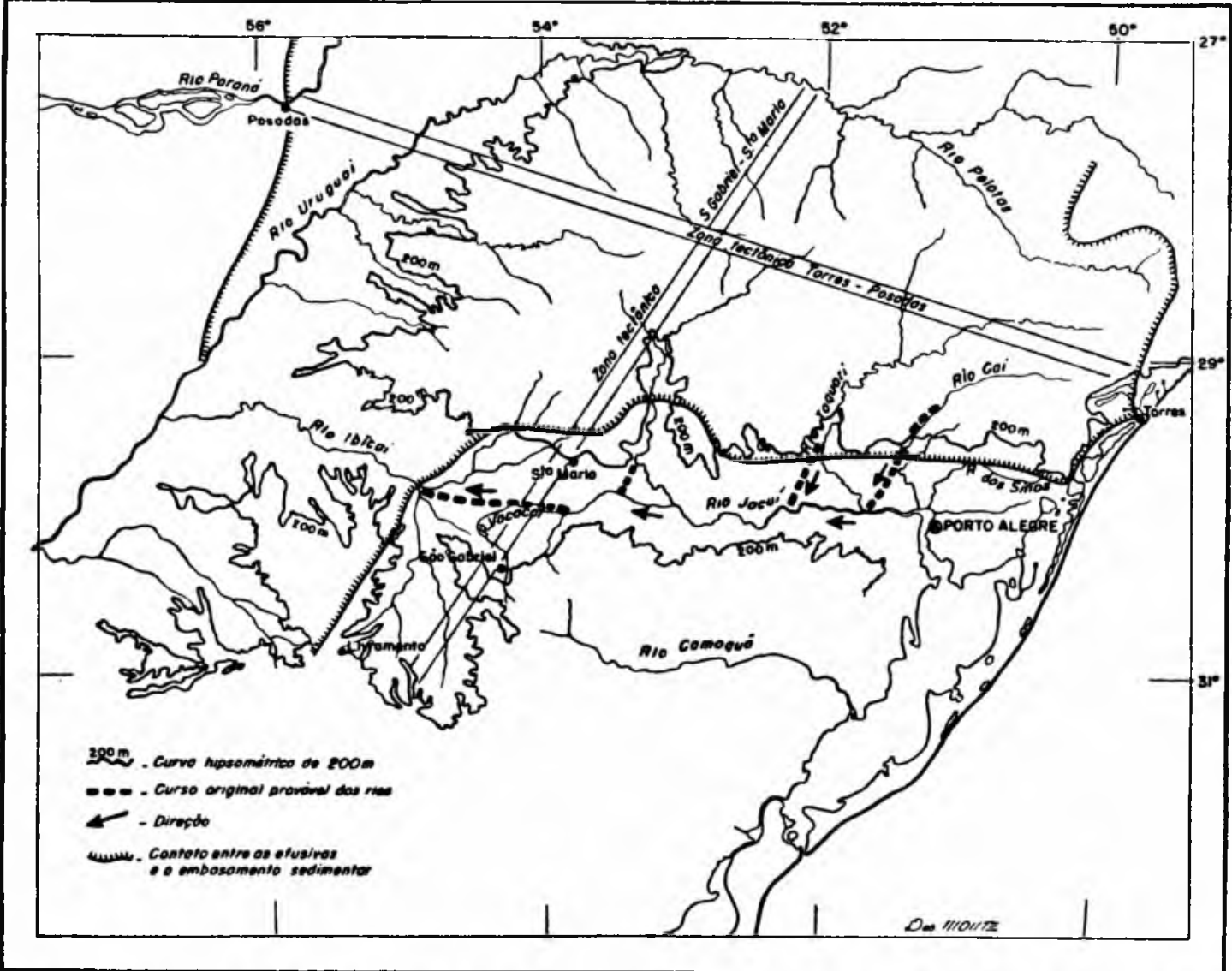

Fig. 22 - Mapa indicando a drenagem fluvial atual e a drenagem provável do passado no Estado do Rio Grande do Sul.

Taquarí. Um aprofundamento de apenas 10-15 metros do divisor d'água permitiria a captura do rio Tainhas num percurso de 15 quilômetros. Uma vez atingida tal captura, é fácil imaginar que a inversão do alto Tainhas, tendo um desnível de 1.000 metros em poucos quilômetros, provocará uma erosão rápida, forçando sucessiva- 
mente novos trechos do Tainhas a inversão. Aliás é possível realizar artificialmente a inversão por meio de um canal, aproveitando-se o seu volume d'água como fonte de energia, numa queda de quase 800 metros.

O segundo bloco, situado a oeste da linha S.Gabriel-Sta. Maria, drena toda a sua água para o rio Uruguai, em forma de rios correndo no sentido do mergulho das camadas, para desembocar no curso dirigente do rio Ufuguai. Também o rio Ibicuí foge em parte a essa regra. Parte dos formadores deste rio nasce no sul do Estado e dirige-se rumo norte, correndo na direção dos sedimentos préefusivos até Cacequí. Daí infletem, como o rio Ibicuí, para oeste, cortando as efusivas, de maneira semelhante ao rio Tietê (S. Paulo) ou Ivaí, Iguaçú (Paraná). É muito provável que o rio Ibicuí seja muito antigo e tenha recebido também, pretèritamente, as águas do rio Jacuí.

\section{ASCENSÃO DO MAGMA BASÁLTICO}

Um dos grandes problemas abertos na vulcanologia é o estudo da causa e o conhecimento do processo da ascenção magmática, que originam derrames gigantescos. $\mathrm{O}$ problema já preocupou, entre outros, Daly (6) e Rittmann (38). Não é possível explicar o mecanismo da efusão com o aumento retrógrado da tensão dos gases devido à cristalização inicial de fenocristais. Assim, interpreta-se a subida ativa do magma em um estado incipiente de cristalização, principalmente nos estratos-vulcões. Chegámos a conclusão, neste trabalho, que a lava ascendeu em estado de fusão completa, isenta de cristais. Mas o magma, a partir do seu estado de superaquecimento, entra numa fase de diminuição da tensão dos gases conjugada com temperaturas descendentes. Ele não pode subir por si mesmo. São forças exteriores e não as próprias do magma que provocam sua subida. Tudo está a indicar que se trata, principalmente, de forças tensionais que reagem sobre a crosta terrestre, abrindo fendas e assim permitindo a subida do magma.

Partimos da pressuposição muito razoável da formação de fendas através de toda a crosta terrestre solidificada, que coloca dessa forma a zona magmática em comunicação com o exterior. 0 magma sofre consequentemente um alívio forçoso de pressão diminuindo assim a sua viscosidade. Gera-se, então, uma pressão diferencial que provoca a penetração do magma na fenda até a obtenção de um equilíbrio hidrostático entre os blocos da crosta e o magma na fenda. Se a densidade da crosta fôr superior à do magma, então há derramamento. Assim se interpreta o caso do vulcanismo da região do Pacifico, onde a crosta possui uma densidade de cerca 3,0 e o magma basáltico uma densidade em volta de 2,8 -2,9. 
Mas em regiōes continentais, o magma com uma densidade de 2,8 - 2,9 é mais pesado do que a crosta com densidade $2,7-2,8$. Sendo assim, o magma não atingirá a superfície e ficará no interior da crosta, provocando a formação de câmaras magmáticas, focos para futuros vulcões ativos. Para o magma poder ascender desempedidamente até a superfície, causando grandes derrames, Daly (6) admite como condição principal o fato de que as fendas devem chegar livremente até a superfície. Nesse caso as partes superiores acham-se sob pressão muito baixa, inferior ainda à pressão baixa do magma. Esta diferença provoca a libertação dos gases no magma. Formam-se, assim, inúmeras bolhas, que diminuem consideràvelmente a densidade e forçam a subida do magma. Os cálculos obtidos por Daly mostram que é possível, por essa forma, a subida passiva de massas magmáticas, cuja parte inferior também logra ràpidamente uma diminuição de pressão e com isso de densidade, permitindo assim a extrusão. As secções da crosta, cobertas pelos derrames afundam-se; dest'arte reduzem-se a largura da fenda e a produção. A perda térmica já não será, agora, suficientemente compensada. A fenda "soldar-se-á" por cristalização do magma, sob a forma de dique, sobrevindo um hiato no derramamento. As forças tensionais continuadas rompem outras fendas e o processo se renova, dando como resultado final numerosos derrames de espessuras consideráveis.

As causas diretas dos derrames são extra e não intramagmáticas e relacionam-se com a abertura primária de fendas profundas. A origem destas é especulativa. Segundo Daly (6), na maioria das vezes, parece ter por causa principal um movimento horizontal pequeno de blocos siálicos.

\section{Proveniência do magma}

Os produtos magmáticos da fase vulcânica aqui tratados são de grande homogenidade, tanto em extensão vertical, como horizontal. Apesar de se ter de admitir que a subida do magma deu-se em vários ou numerosos lugares diferentes, a semelhança dos produtos fornecidos é impressionante. Porçosamente chega-se à conclusão de que todo o magma provém de uma única fonte original e de composição homogênea. Geralmente admite-se que o fornecedor do material para os derrames basálticos é o sima, quando atingido por geoclases. As pesqusias sismológicas segundo $\mathrm{v}$. Bemmelen (4) demonstram, entretanto, ser a "Tectonosfera", (esfera composta de camadas de densidades crescentes sob a forma descontínua) a provável fonte. Assim, deve-se admitir a existência, no mínimo, de uma camada intermediária entre o sial e o sima, denominada "Salsima", possuindo densidade de 2,8 - 2,9 $\mathrm{Pa}$ rece que os basaltos de fissuras são produtos desta camada intermediária ou salsima. 


\section{Causas da formação das fendas}

O ciclo diastrófico que permitiu a ascenção das massas magmáticas no sul do Brasil manifestou-se sob a forma de esforços tensionais e não de compressão, fato para o qual Oliveira e Leonardos (32) e outros chamam a atenção. São geoclases que se abriram, acompanhadas de inúmeras fendas secundárias, segundo linhas pretéritas nas direções nordeste e noroeste. As causas dessa manifestação tectônica podem ser ventiladas apenas de modo especulativo, dependendo do conceito geral das forças tectônicas aceito pelo interpretador Ou ele aceita as causas primárias, de deslise horizontal de blocos siálicos, como postuladas por exemplo por Wegener, ou ele se inclina para a aceitação de movimentos ativos do sima, de origem intratelúrica, com suas variantes expressas na teoria da pulsação (Grabau e Bucher), da undação (v. Bemmelen), da oscilação (Haarman) Conforme a posição do autor em relação a estas hipóteses básicas, assim ele interpretará os resultados tectônicos observáveis na superfície.

A concordância cronológica aproximada da subida das lavas basálticas no antigo continente gondwânico é explicada por qualquer das hipóteses citadas. Mas os dados brasileiros indicam uma grande semelhança com o seu correspondente africano. Bôa parte dos geólogos brasileiros (o autor inclui-se nela), julga por isto que a teoria das translações continentais, não aplicada de forma demasiadamente ortodoxa, explica satisfatòriamente o maior número de fenômenos. Não é este o lugar para discutir essas comparações. Está fóra de dúvida, entretanto, que a admissão da mobilidade transversal dos tratos siálicos explica razoàvelmente o aparecimento de fendas nos blocos, manifestadas como geoclases. Mesmo Daly (6), que não é muito favorável à teoria de Wegener, admite como causa da abertura de fendas adutoras do "sima" as translações horizontais de blocos siálicos.

Os esforços tectônicos de tensão manifestaram-se com grande intensidade em certas zonas, formando um geoclasamento pronunciado e fornecendo assim os adutores primários do magma. Lembramos como protótipo dessas faixas a zona tectônica Torres-Posadas. $\times$ Abriram-se simultâneamente inúmeras fendas secundárias, com maior frequência e amplitude perto das faixas tectônicamente fracas. Nelas infiltrou-se o magma derivado das adutoras principais, formando os inúmeros diques de diabásio no Brasil que são provàvelmente o produto do mesmo ciclo diastrófico.

\section{Os sills e sua importância}

Existe uma dependência geográfica entre sills e derrames. Até agora tem-se encontrado sill sòmente na vizinhança dos derra- 
mes. No Estado de S. Paulo, estes afloram principalmente nos contatos Iratí-Tubarão e estão distantes dos afloramentos atuais no máximo 50 quilômetros. No sul de Santa Catarina, nas proximidades de Treviso, ocorre um sill de grandes dimensões a cerca de 20 quilômetros dos afloramentos atuais dos derrames.

Embora na orla meridional da escarpa do Rio Grande do Sul não se encontrem sills, os morros testemunhos mostram claramente que houve um desgaste erosivo na escarpa formada de lavas decerca-de 30-40 quilômetros de extensão no mínimo. ções:

Assim, cremos que a formação de sill liga-se a duas condi-

1 - Vizinhança da região produtora de magma.

2 - Regióes cobertas originalmente por efusivas.

A segunda condição parece-nos comprovada pela vizinhança dos sills aos derrames. Usamos a expressão sill como um termo vulcanológico. Ele indica que a resistência do tecto era superior à resistência de penetração lateral. Como de outro lado temos que admitir fendas abertas para produzir os derrames, são os sills o sinal de condutos de lava solidificada, que forçaram o magma ainda existente nas vias de acesso para a penetracão lateral. Pode-se imaginar, também, que o magma proveniente dos condutos principais foi desviado para fendas secundárias que não atravessaram os derrames, forçando uma pequena parte do magma ascendente em câmaras fechadas. Devemos admitir sempre um tecto "resistente", que os derrames puderam fornecer provàvelmente na sua maioria. Inclinamo-nos pela primeira hipótese, de que os grandes sills são os produtos de vias de acesso exaustos e consolidados.

Lembramos aqui que em magmas pouco viscosos, a pressão intrusiva se transmite sob forma hidrostática.

O fato dos sills se localizarem na sua maioria no contacto Iratí-Tubarão, poderia indicar preferência litológica para com o calcáreo. Essa idéia é para nós de difícil aceitação devido à ausência quase absoluta de metamorfismo ou assimilação. $\mathrm{Pa}$ rece-nos muito mais provável que esta preferência seja apenas uma expressão da resistência do tecto e da pressão "injetora" do magma. Esta atinge um "optimum" a certa profundidade, em dependência da carga, isto é, da espessura do tecto. Como a espessura dos sedimentos gondwânicos é pràticamente idêntica, é presumível que o contacto entre estas duas formações corresponderia à "isobata" do optimum para a injeção magmática.

Seria interessante estudar, com as minúcias necessárias, alguns sills com sua capa sedimentar parcialmente conservada, afim de obter dados precisos sobre as deformações tectônicas provocadas pelo "sill" Qualquer estudo visando a localização de estruturas petrolíferas não deve descurar desse problema. 


\section{As regiōes do extravasamento magmático}

Possuimos dados suficientes para reconhecer a, ou, as regiões do extravasamento do magma. Temos que admitir, a priori, que uma área tão vasta deve possuir vários focos de derramamento e não apenas um.

Os indícios são os seguintes:

1 - Espessuras maiores dos derrames perto dos focos e adelgaçamento centrífugo. 2 - A ocorrência de sills e sua frequência indicando áreas produtoras. $3-$ Falhamento e diques indicando áreas tectônicas e propícias ao extravasamento. 4- Texturas fluidais e inclinação das soleiras, indicando o sentido da corrida.

Esses 4 indícios ocorrem conjuntamente no Rio Grande do Sul e Santa Catarina, na linha tectônica Torres-Posadas, enquanto na área ao sul da escarpa Osorio-Sta. Maria não se registram. Devemos admitir, consequentemente, que a linha Torres-Posadas é uma das zonas fracas que permitiram um vasamento intenso.

Desconhecemos a largura real dessa faixa, mas sem dúvida, atinge um certo número de quilômetros. Assim, as corridas de lava tomaram um rumo sul a sudoeste, percorrendo uma distância de-cerca-de 100 quilômetros. Corridas de lava dessa extensão enquadram-se muito bem dentro das observações atuais. Assim Daly (6) menciona uma corrida de lava na Islândia de 90 quilômetros de comprimento.

Sem dúvida a zona de extravasamento forneceu, também, corridas magmáticas com rumo norte e noroeste, atingindo talvez a área de Lages.

Esta zona produtiva este-oeste, com seu prolongamento provável no Atlântico, explica o esporão saliente da serra Geral em Santa Catarina e Rio Grande do Sul.

Evidentemente tal faixa não é a única produtora para o Rio Grande do Sul. Observamos alguns indícios que nos permitem apontar outras áreas produtivas. Por considerações de ordem negativa deduzimos que uma ou outra zona de derramamento deve ocorrer na região do atual vale do Uruguai. As razões são as seguintes: na área Livramento-Sta. Maria, formada por sedimentosgondwânicos em contacto com os derrames, faltam por completo ocorrências de sill - indicadores de adutores magmáticos. Estão ausentes também os diques, indicadores de fraturas singenéticas ao vulcanismo. As poucas texturas fluidais observadas indicam uma corrida de lava oeste-leste ou leste-oeste. A ausência completa de indícios de zonas produtoras no lado leste, e a espessura considerável de derrames de 400 metros observada em uma sondagem ao norte de Salto (Uruguai) implica na admissão de que o vasamento se realizou em fendas situadas na região do vale do Uruguai, derramando-se a lava tanto para leste como para oeste. Também, aqui: os derrames percorreram cerca-de 100 quilômetros rumo leste. 
Provàvelmente seja a continuação da linha S. Gabriel-Sta. Maria a zona de encontro dos derrames vindos do norte e do oeste. Sem dúvida esta linha tectônica não é uma zona fornecedora. Caso contrário ela deveria evidenciar as condições n. ${ }^{\circ} 1,2$ e 3 , bem representadas em zonas produtoras.

A linha do vale do Uruguai possivelmente continua rumo nortesul, ainda pelo vale do Paraná afora.

Outra zona produtora é a margem oriental da escarpa em São Paulo. Aqui, observam-se como indício significativo, numerosos sills, diques e falhas e, como também foi observado por Washburne (46), texturas de corridas e falhas indicando um fluxo rumo oeste, enquanto na região de Sete Quedas (Paraná) esse autor encontrou indícios de rumos norte-sul. A zona de São Paulo não parece ter uma orientação definida, e sim compor-se de fendas de duas direções, como que "brechando" extensivamente o embasamento. Mas é bem possível tratar-se de uma larga zona de perturbação, com rumo principal norte-sul coberta ainda hoje pelos derrames. Não realizamos ainda estudos mais detidos sobre o problema para averiguar se o eixo da bacia do Paraná foi uma zona produtora intensa ou se os derrames se originaram na zona norte da bacia, nas margens, convergindo e derramando rumo ao eixo. Fica ainda aberta a questão, ambas as possibilidades estando de pé. Washburne (46) é de opinião que as áreas produtoras de lava situam-se na periferia da bacia do Paraná, afluindo os derrames para o eixo da bacia. Acredita, assim, que as lavas sejam mais delgadas nas proximidades do Rio Paraná do que mais a leste.

O prosseguimento, em outras regiões, de estudos semelhantes. aos divulgados no presente trabalho trará, sem dúvida, solução a esse problema.

Chegámos assim à conclusão de que existem: 1. Zonas produtoras de lava e transversais ao eixo da bacia do Paraná exemplificadas pela faixa Torres-Posadas. 2. Zonas longitudinais a esse eixo, como a zona produtora inferida do vale do Uruguai. 3. Zonas marginais ao eixo da bacia do Paraná, encontradas na orla oriental dos derrames no Estado de São Paulo (Fig. 1)

Não podemos julgar por enquanto qual teria sido o sistema preferencial na bacia em conjunto, mas somos inclinados a aceitar, como mais provável, o sistema $n^{\circ} 2$ conjugado, em parte, com o de n. ${ }^{\circ} 1$.

\section{E. RESUMO}

O objetivo deste trabalho foi o estudo geológico dos fenômenos vulcanológicos ligados às efusivas (rético?) da bacia do $\mathrm{Pa}$ raná. São fornecidos, principalmente, pormenores da área dos Estados do Rio Grande do Sul e Santa Catarina. Os resultados atingidos são os que seguem: 
1. A idade das atividades vulcânicas está limitada entre o triássico superior e o cretáceo superior, possivelmente entre o rético e o jurássico.

2. A área ocupada pelas efusivas contínuas soma cerca de um milhão de quilômetros quadrados, da qual aproximadamente a metade está coberta por sedimentos mais modernos.

3. As espessuras foram observadas na orla oriental da bacia onde as efusivas formam escarpas pronunciadas. A espessura máxima, de 1.000 metros, encontra-se nas proximidades de Torres, Rio Grande do Sul. Ela decresce tanto para sul como para norte e, partindo desse ponto, atinge nos extremos norte e sul poucas dezenas de metros. O volume das efusivas, calculado com este último dado, é de 350 mil quilômetros cúbicos. (Fig. 2).

4. O lençol das efusivas é constituido de vários derrames sucessivos. Nos perfis mais completos foi possível a verificação de oito a treze corridas de lava, separadas por um hiato. Este é reconhecível pelas intercalações de pequenos bancos de arenito e, na sua falta, pelas texturas vesiculares e vítreas conjugadas com diaclases horizontais no topo e na base de cada derrame. As espessuras individuais variam desde poucos metros até 80 metros. (Figs. 1, 6, 7)

5. Os derrames ocorreram sobre planos pràticamente horizontais e possuem mergulho de poucos metros por quilômetro, verificado por nivelamento de precisão. Observa-se, frequentemente, uma textura fluidal provocada pela orientação das vesículas nos basaltos. Medidas desta textura, em vários lugares, indicam dois sentidos da corrida de lava (Fig. 13).

6. Atividades explosivas do vulcanismo são raras vezes observadas e limitam-se a ocorrências locais dos próprios derrames.

7 Encontram-se, muito frequentemente, nas regiões adjacentes aos derrames, jazimentos intrusivos do vulcanismo sob a forma de sill e dique. Certos sills ocupam áreas de centenas de quilômetros quadrados e com espessura aproximada de 200 metros. (Fig. 14)

As espessuras dos diques variam de poucos metros a dezenas de metros. O máximo da frequência de diques observa-se no sul do Estado de Santa Catarina, onde ocorrem 15 diques numa distância de 20 quilômetros.

8. A composição mineralógica e química do magma basáltico é homogênea, sendo constituida principalmente de plagioclásio $\left(A n_{50-70}\right)$, augita e pigeonita. Contudo, foram encontradas efusi- 
vas mais ácidas, de tipo leidleito, no topo dos derrames. Os termos efusivos são caracterizados por uma textura basáltica rica em mesostasis vítrea, e os termos intrusivos se destacam pela textura ofítica.

No perfil Três Forquilhas-Tainhas estudos pormenorizados mostraram a variação e o alto teor de material vítreo contido nos basaltos (Fig. 16).

A tabela n..$^{\circ} 3$ resume as análises químicas das efusivas brasileiras até agora realizadas. Delas, 4 são novas. Pode-se notar a pequena variação na constituição, exceto nos leidleitos e a semelhança do magma basáltico do Brasil com os magmas de outros derrames gondwânicos.

9. Insignificantes são os fenômenos endo- e exo-metamórficos. O embasamento arenítico pré-efusivo sofre apenas silicificação intersticial. Xenolitos são muito raros nos basaltos; um de granito, proveniente de, no mínimo 1.500 metros de profundidade, apresenta apenas uma auréola de reação de um centímetro de espessura. $\mathrm{Na}$ zona de reação o plagioclásio transforma-se parcialmente num esqueleto celular de vidro incolor (Fot. 9)

10. O embasamento das efusivas é constituido de arenitos eólicos triássicos, da formação "Botucatú" A posição do contacto entre este embasamento e a efusiva é dada na tabela n. ${ }^{\circ} 1$. O ponto mais baixo deste contacto acha-se perto de Torres, Rio Grande do Sul, e quase ao nível do mar. Sobe bruscamente, rumo norte, para 650-750 metros e mantém-se quase neste nível até o Estado de São Paulo. De Torres para o sul o contacto sobe suavemente até atingir 270 metros em Sta: Maria (Fig. 2)

11. Foi observado um certo número de falhas diretas no embasamento, com rejeitos de até 30 metros (tabela n..$^{\circ}$ ) As efusivas também possuem indícios de falhamento em forma de zonas milonitizadas.

Destacam-se duas direções de perturbações: uma em volta de NNE e outra em volta de NW

12. E provável a existência de uma linha tectônica importante, entre Torres-Posadas, com base nas seguintes observações: os sedimentos glaciais (carboníferos?) denunciam ao sul desta linha uma erosão glacial intensa com pouca sedimentação e ao norte intensa sedimentação com invasão marinha. Falhamentos frequentes do embasamento, nesta zona, antecederam as atividades magmáticas. Durante e depois do vulcanismo esta zona servia de "dobradiça" dos movimentos tectônicos que inclinaram o embassamento sedimentar no sentido convergente dessa faixa tectônica. 
As efusivas atingiram aqui sua espessura máxima, indicando uma das zonas do extravasamento magmático. Também o lombo submarino denominado "riograndense" liga-se a esta faixa. (Figs. $13,17,21$ )

13. A formação das escarpas morfológicas a partir das efusivas poderia ter-se dado, para o caso do Rio Grande do Sul, por extravasamento magmático sucessivo de derrames do mesmo volume e viscosidade, confinando-se aproximadamente no mesmo lugar. Formou-se um pacote composto com términos mais ou menos abruptos. A erosão apenas remodelou a escarpa original, deixando-a retroceder 30 quilômetros no mínimo. Numerosos morros de testemunhos, na frente da escarpa, foram assim formados.

O beiral abrupto da escarpa perto do oceano Atântico (Rio Grande do Sul) deve ter-se originado de falhamentos relativamente modernos, como indicam as falhas perto da lagôa dos Patos e a drenagem fluvial muito juvenil desta escarpa.

14. Concluimos que o magma subiu em estado de completa fusão, sem cristalização incipiente. Para explicar a causa da subida do magma recorremos à hipótese de Daly As causas diretas, extra e não intramagmáticas, relacionam-se com a abertura primária de fendas profundas.

- A homogeneidade do magma indica sua proveniência do sima, ou melhor do salsima. A abertura das geoclases foi provocada por esforços tensionais e a relacionamos com os movimentos de deriva segundo Wegener Como indícios de regiōes de extravasamento magmático consideramos os seguintes fatos: - espessuras maiores dos derrames perto dos focos e adelgaçamento centrífugo, - ocorrências de sill, — falhamentos e diques, - texturas fluidais e inclinação das soleiras dos derrames.

Estes indícios ocorrem conjuntamente na faixa tectônica Torres-Posadas, de onde se derramou a lava rumo sul e norte num percurso de, aproximadamente, 100 quilômetros. Acreditamos na existência de outras zonas produtoras. Duas faixas localizam-se na região do atual vale do Uruguai e na margem oriental da escarpa em São Paulo.

Existem assim zonas produtoras transversais (Torres-Posadas). langitudinais (Uruguai) e marginais (São Paulo), ao eixo da bacia do Paraná (Fig. 1). 


\section{F BIBLIOGRAFIA}

1. Almeida, F F. M. - Basaltos do Planalto de Maracajú - No prelo.

2. Azambuju J. J. R. A. - Arenito vulcano-clástico intertrapeano de Irai, R. G. do Sul - Mineração e Metalurgia, vol. VII, 1944 .

3. Baker, CH. L. - The lava field of the Paraná basin, South $؟$ America - Journ. of Geol., XXXI, n. 1, 1923.

4. Bemmelen, R. W - Das Permanenzproblem nach der Undations-theorie - Geologische Rundschau, III, 1939.

5. Carvalfo, P F. - Reconhecimento geológico no Estado do Rio Grande do Sul - Serv. Geol. Min., Bol. 66, Rio de Janeiro, 1932 .

6. Daly, R. A. - Igneous Rocks and the Depths of the Earth New York-London, 1933.

7. Du тоIт, A. L. - Pipe Amygdaloids - Geol. Mag. 4, 1907

8. . . . - Our Wandering Continents. An Hypothesis of Continental Drifting - London, 1937.

9. .. ..-The Geology of South Africa - London, 1939.

10. ..... - Comparação Geológica entre a América do Sul e Africa do Sul. Trad. K. E. Caster e J. C. Mendes No prelo.

11. Gordon, Jr., M. - Classification of the Gondwanic Rocks of Paraná. Santa Catarina and Rio Grande do Sul - Div. Geol. Min., Notas prel. e estuds., N. ${ }^{\circ} 38$, Rio de Janeiro, 1946.

12. Guimarães, D. - A provincia magmática do Brasil Meridional - Dep. dos Serv. Geogr. Geol., Monogr., n. 1, Belo Horizonte. 1933 .

1D. . . . . - Contribuiçôes mineralógicas e petrographiInst. de Tec. Industr., Bol. 1, Belo Horizonte, 1946.

14. .. ... . . . . - Origem das rochas alcalinas - Inst. de Tec. Industr., Bol. 5, Belo Horizonte, 1947

15. Hausen, J. - Contribución al estudio de Petrografia del Territorio Nacional de Misiones - Min. de Agr., Bol. n. 21, Buenos Aires, 1919.

16. Huene, F. v. - Terrestriche Oberkreide im zentralen Südamerika - Cbl. f. Min. Geol., Abt. B, 1930.

17. .. ....\& \& StAHLECKER, R. - Geologische Beobachtungen in Rio Grande do Sul - N. Jb. Min. Geol., B. B. LXV, 1931.

18. HussaK, E. - Notas petrographicas sobre augito-porphyritos de Paranapanema - Com. Geogr. Geol. da Provincia, Bol. n. 2, S. Paulo, 1889 .

19. .... - Contribuições mineralógicas e petrographicas - Com. Geogr. Geol. do Estado, Bol. n. 7, S. Paulo, 1890. 
20. JACOBSEN, W. - Vulkanologische und tektonische Beobachtungen an der jungalgonkischen Venterdord-Formation Südafrikas - Geol. Rundschau 31, 1940.

21. Krenkel, E. - Geologie Afrikas - II. Teil - Berlin 1928.

22. LAMBERT, R. - Estado actual de nuestros conocimientos sobre la geologia de la República Oriental del Uruguay - Inst. Geol. Uruguay, Bol. n. 29, Montevideo, 1941.

- 23. Leinz, V - Estudos sobre a glaciação Permo-carbonifera do Sul do Brasil - Serv. Fom. Prod. Min., Bol. n. 21, Rio de Janeiro, 1937

24.

.. - Observações nos contactos de diabasio com sedimentos - Serv. Geol. Min., Notas prel. e estuds.j n. 7, Rio de Janeiro, 1937

25. : .. \& Fontoura, M. L. \& Gomes, V. M. - Notações petrographicas sobre algumas analyses chimicas - Congr. Sul-Amer. de Chimica, Rio de Janeiro, 1937

. 26 .

27. ... - A silicificação nos sedimentos gondwani$\cos$ no Sul do Brasil e sua origem - Serv. Fom. Prod. Min., Publicação Especial, n. 5, Rio de Janeiro, 1938.

ça, $\dot{R} . \ddot{G} . \ddot{S}$. - Mineração e Metalurgia, V. XIII, n. 73, 1948.

28. MaAłk, R. - Geographische und geologische Forschungen in Santa Catarina - Gesells. f. Erdk., Berlin, 1937

29. MAACK, R. - Breves noticias sobre a geologia dos Estados do Paraná e Santa Catarina - Inst. Biol. e Pesq. Tecn., Curitiba, 1947

30. Moraes Rego, L. F de - Notas sobre a geomorfologia de São Paulo e sua genesis - Inst. Astr. e Geogr. de São Paulo - São Paulo, 1932.

31. Nacken, R. - Uber die hydrothermale Entstehung der Achatmandeln im Gestein - Die Naturwissenschaften 5, 1917.

32. Oliveira, A. I. \& Leonardos, O. H. - Geologia do Brasil Rio de Janeiro, 1943.

33. Oliveira, E. P - Geologia e recursos minerais do Estado do Paraná - Serv. Geol. Min., Monogr. n. 6, Rio de Janeiro, 1927

34. Oppenheim, V. - Rochas Gondwanicas e Geologia do Petroleo do Brasil Meridional - Serv. Fom. Prod. Min., Bol. n. 5, Rio de Janeiro, 1934.

35. PaIva, GL. - Geologia do municipio de Lages, Santa Catharina - Serv. Min., Bol. n. 69, Rio de Janeiro, 1933.

36. Philip, H. - Beitrag zur Kenntnis der Bewegungsvorgänge in hochviskosen geologischen Flüssigkeiten - Ctrbl. f. Min. usw. - 1921.

37. Price, L. I. - Sôbre um novo Pseudosuquio do Triássico Superior do Rio Grande do Sul - Div. Geol. Min., Bol. n. 120, Rio de Janeiro, 1946.

38. RItTmann, A. - Vulkane und ihre Tätigkeit - Stuttgart, 1936.

39. Rocha, J. F \& ScorzA, E. P. - Estratigrafia de Carvão em Santa Catarina - Div. Geol. Min., Bol. n. 104, Rio de Janeiro, 1940 .

40. SiemiradzK1, J - Geologische Reisebeobachtungen in Suedbrasilien - Sitzungsberichte K. Akad. d. Wiss. Wien, 1898. (Em Ed.Suess "La Face de la Terre" Paris, 1921). 
41. Stocks, TH. \& Wust, G. - Die Tiefenverhaltnisse des offenen Atlantischen Ozeans - Wissenchaftliche Ergebnisse der Deutschen Atlantischen Expedition auf dem Forschungs und Vermessungschiff "Meteor" Bd. III. 1935.

42. Trõger, W. - Spezielle Petrographie der Eruptivgesteine Berlin, 1935.

43. Wadia, D. N. - Geology of India - London, 1944.

44. Walther, K. - - Contribución al conocimiento de las rocas basalticas de la formación de Gondwana en la America del Sur - Inst. Geol. 'y Perf., Bol. n. 9, Montevideo, 1927

45. . . . ... - Eruptivos afro-brasileño-argentinos de edad permotriasso-eojurásica. - La supuesta uniformidad del magma melafirico $y$ sus relaciones com la parentela alcalinitica - Inst. Geol. y Perf., Bol. n. 24, Montevideo, 1938.

46. Washburne, CH. W. - Petroleum Geology of the State of São Paulo - Com. Geogr. Geol., Bol. n. 22, S. Paulo, 1930.

47 WIndhausen, A. - Geologia Argentina - Buenos Aires, 1931.

48. White, I. C. - Relatorio sobre as Coal Measures e rochas associadas do Sul do Brasil - Com. Estudos das Minas de Carvão de Pedra, Relatorio final - Rio de Janeiro, 1908.

49. Woonworth, J. B. - Geological expedition to Brazil and Chile, 1908-1909 - Harvard College, Mus. Comp. Zool., v. LVI, n. 1, Cambridge, Mass., 1912. 



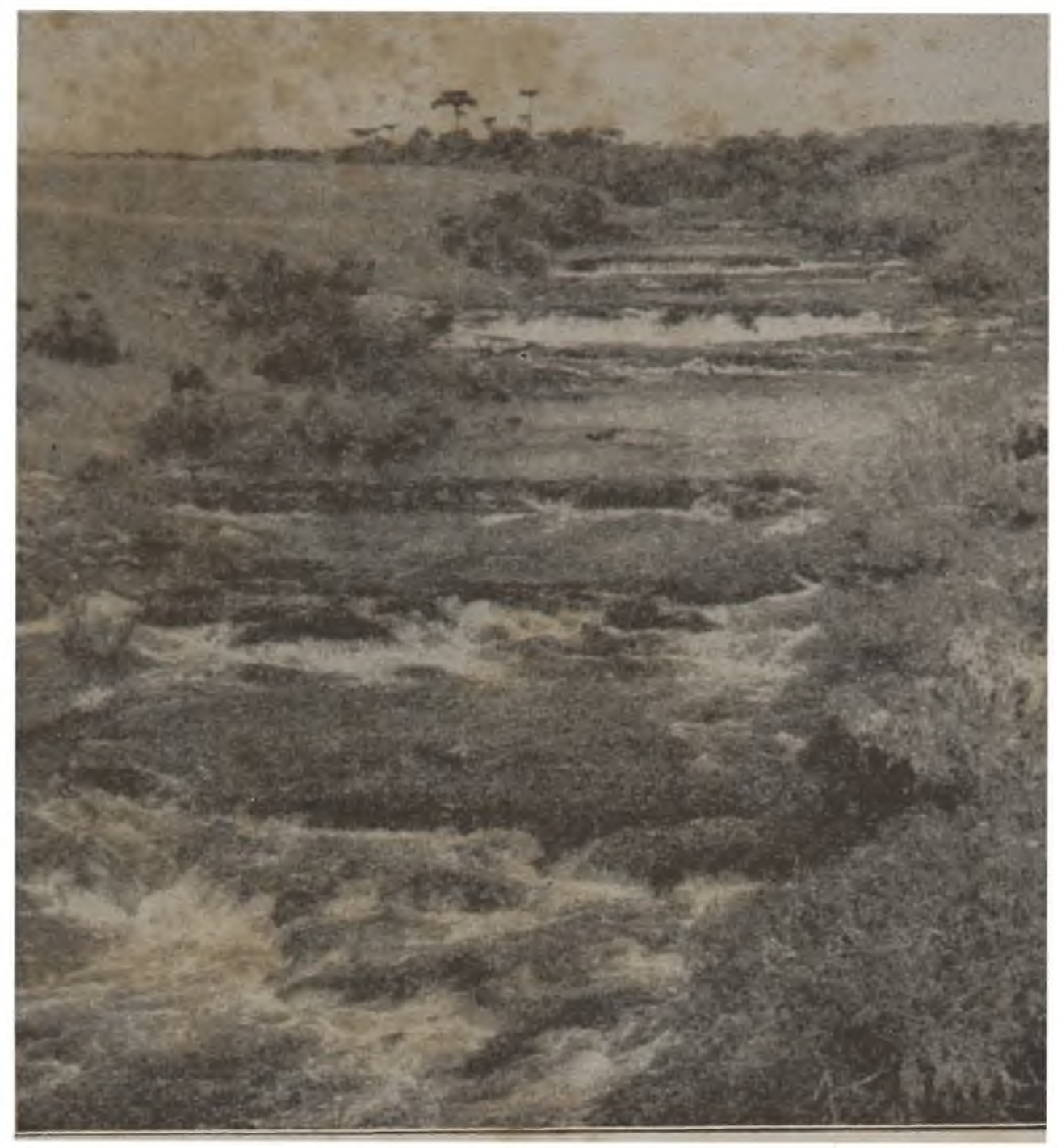

Foto 1 - "Saltos" pequenos sucessivos no basalto com diaclase horizontal; Rio Tainhas, Rio Grande do Sul.

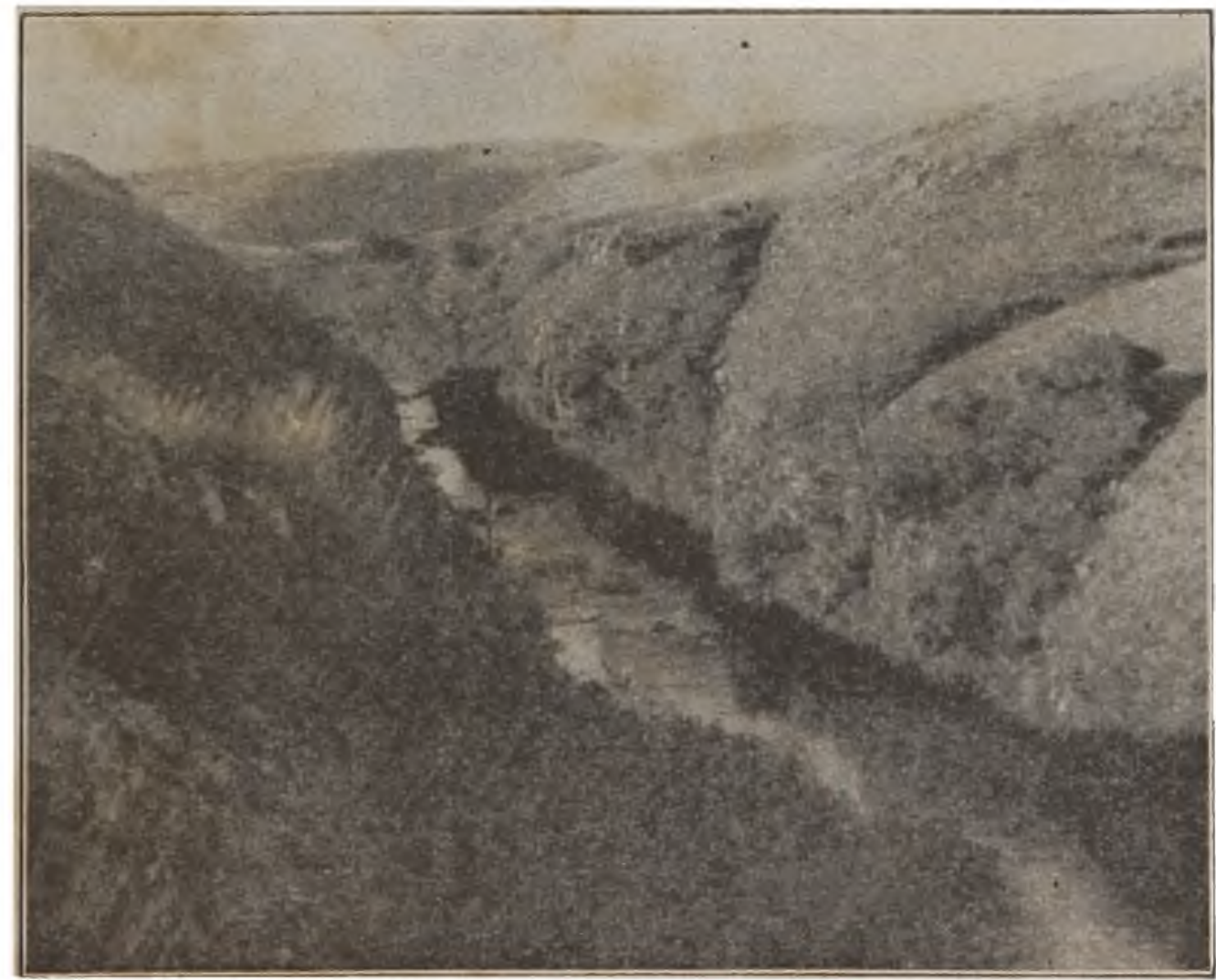

Foto 2 - Canalão (canyon) no basalto com diaclases vertical em continuação do Fot. 1. 


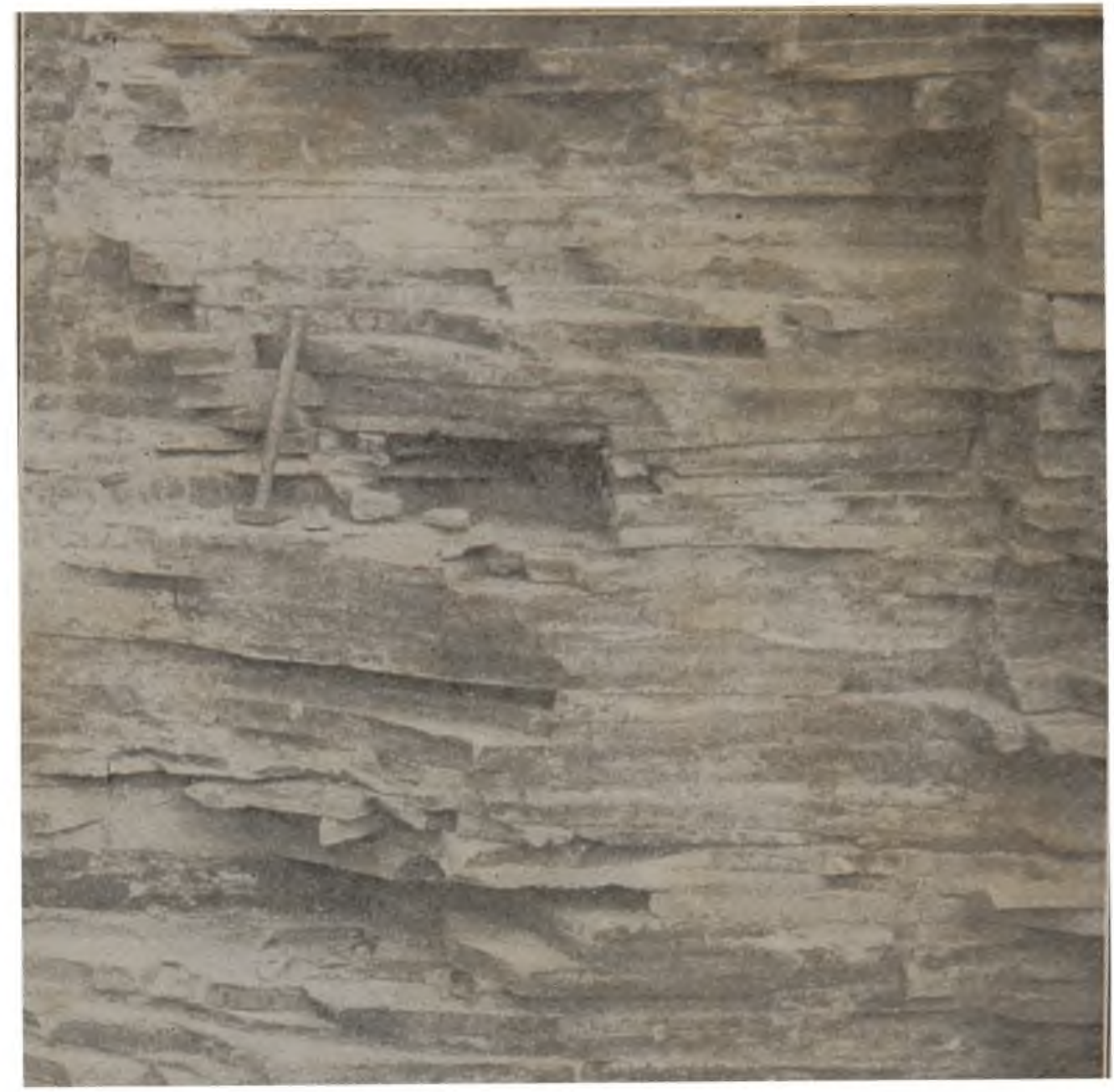

Foto 3 - Diaclasamento horizontal no basalto; Três Forquilhas, Rio Grande do Sul.

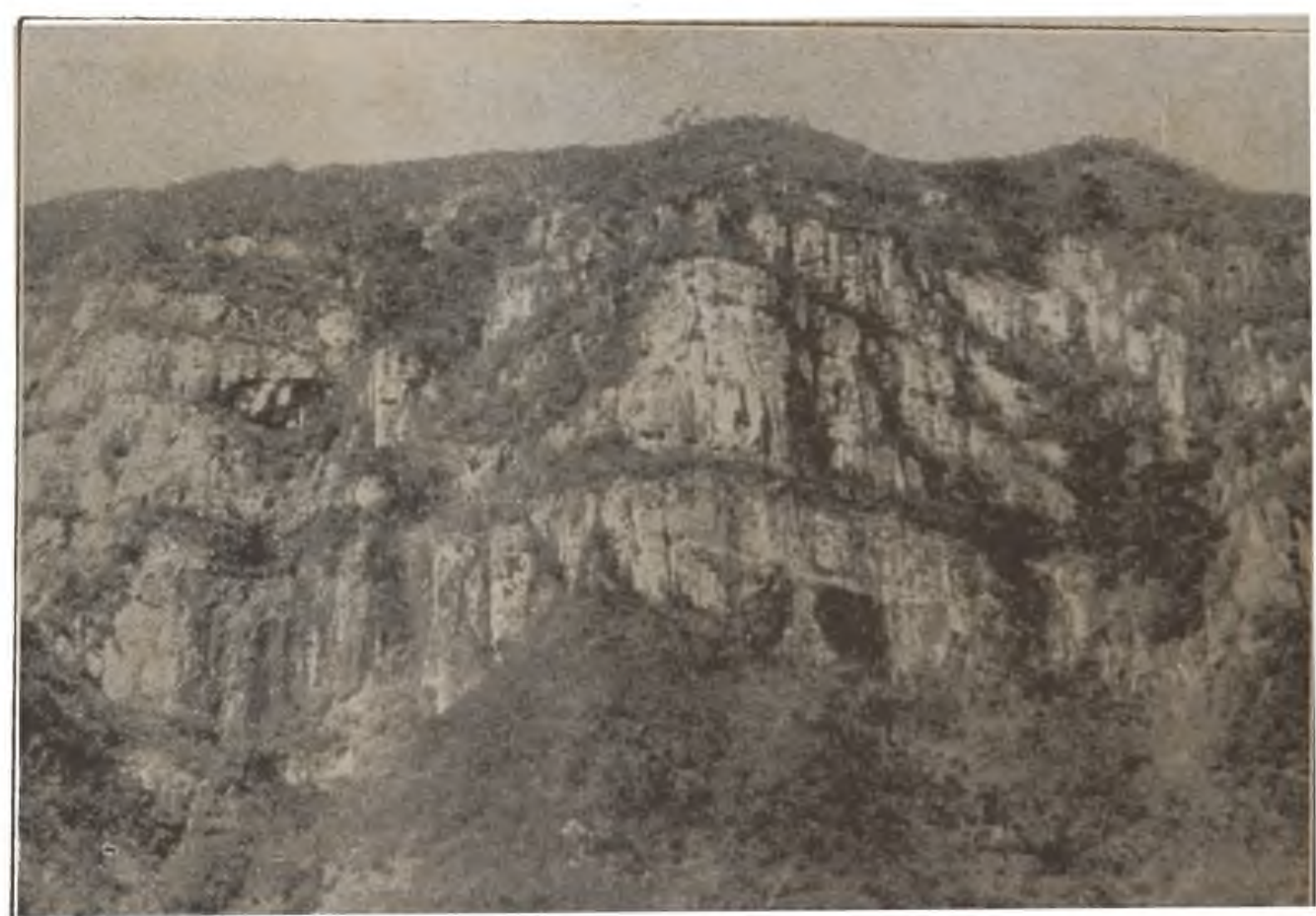

Foto 4 - Escada morfológica produzida por derrames sucessivos; escarpa Lauro Müller-S. Joaquim, Santa Catarina. 


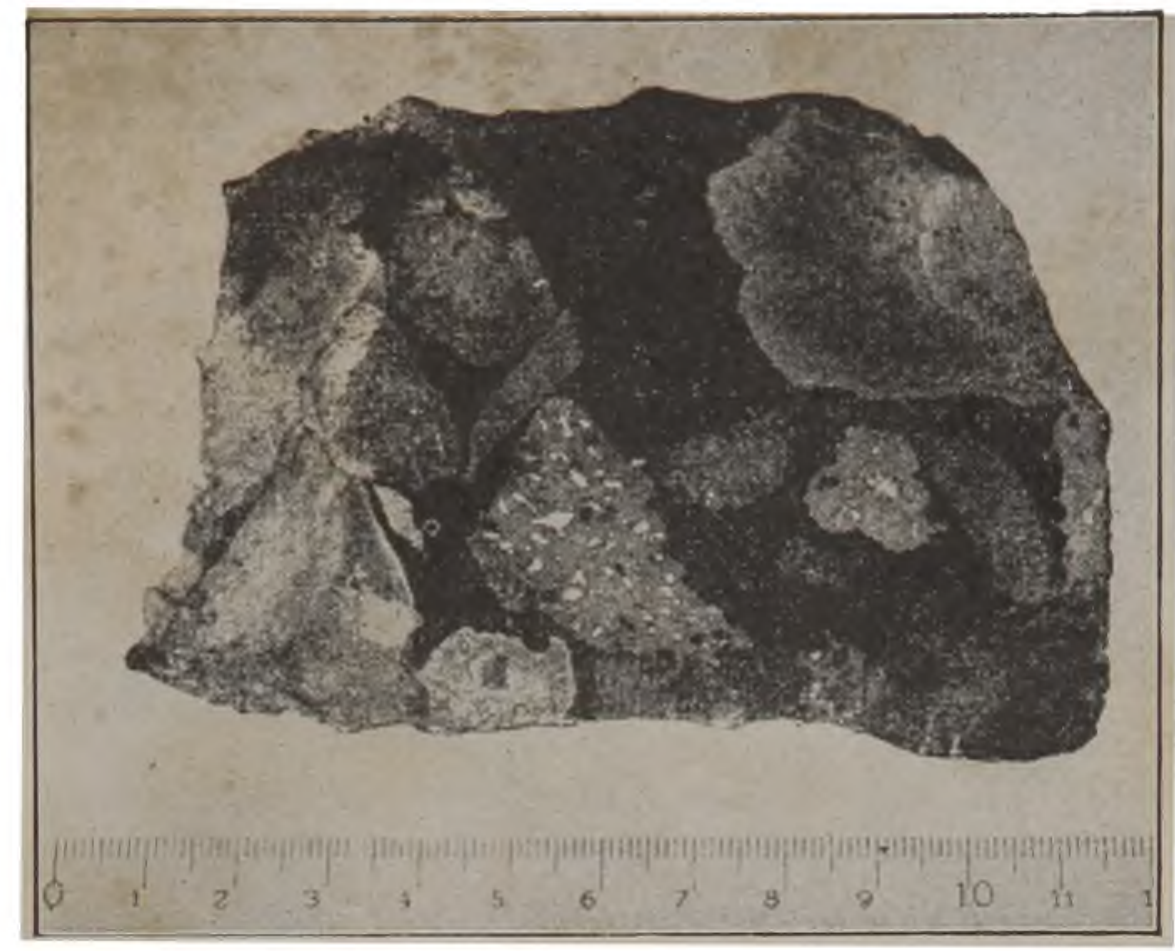

Foto 5 - Rocha piroclástica contendo fragmentos irregulares de basalto vesicular; Guarapuáva, Paraná, Col. P. de Lima.

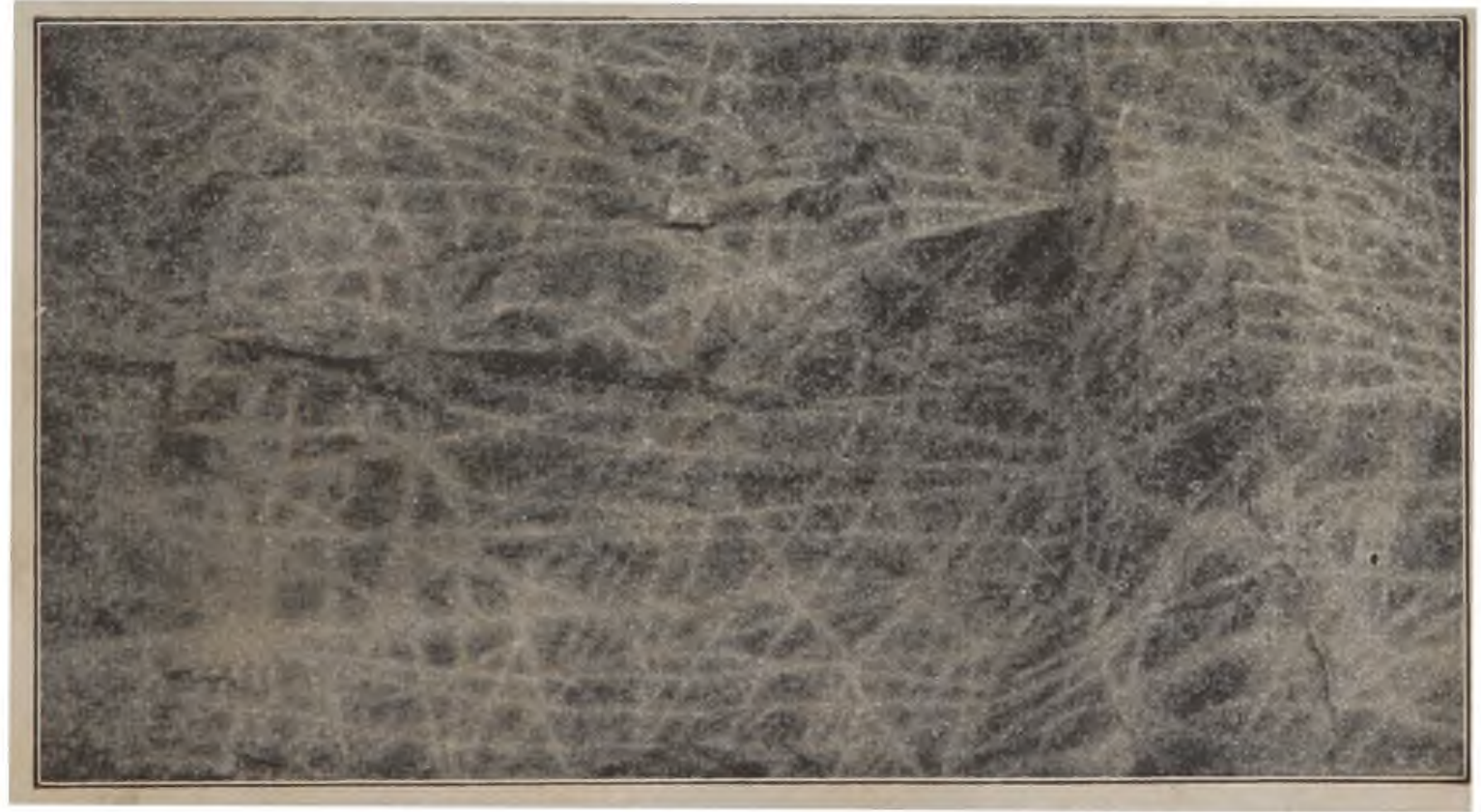

Foto 6 - Leidleito avermelhado cortado por uma rêde de faixas descoradas por percolação: Três Forquilhas-Tainhas, Rio Grande do Sul 


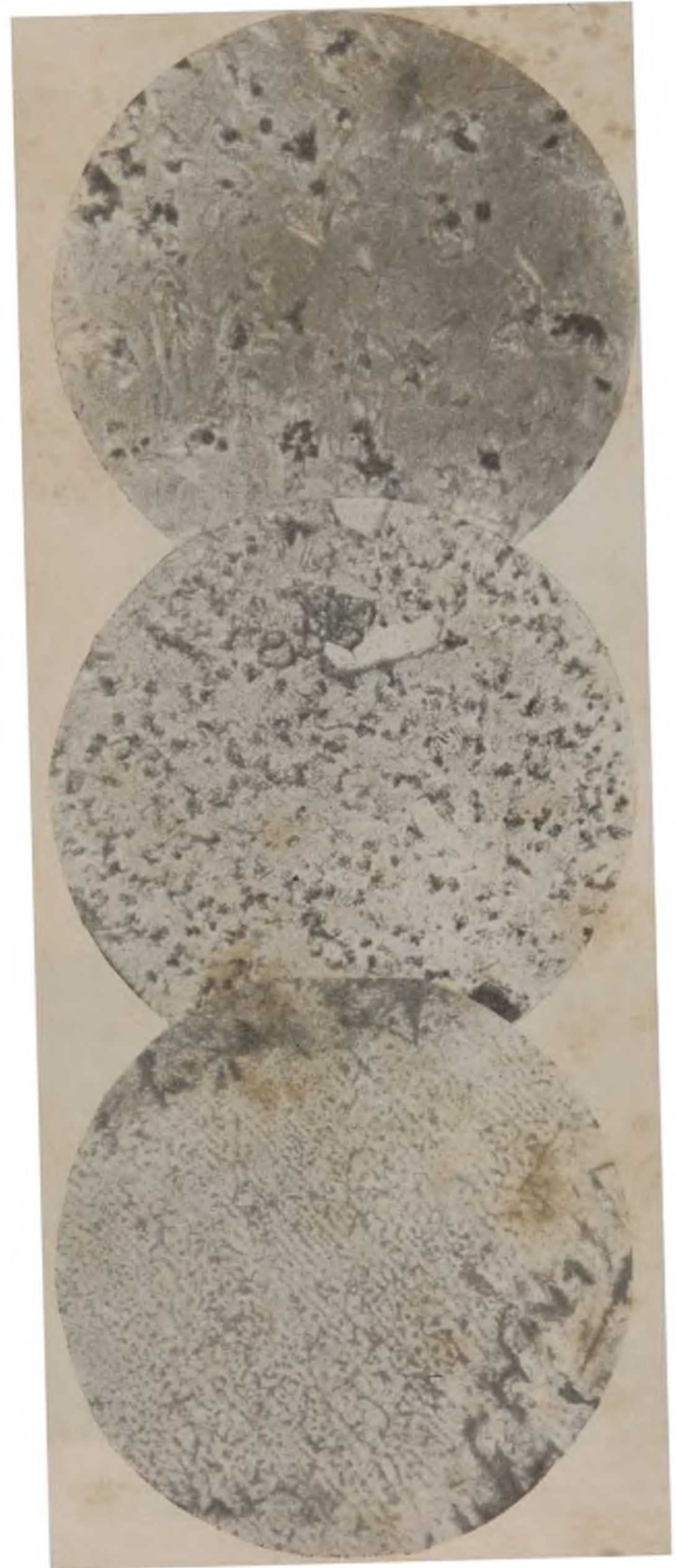

Foto 7 - Leidleito; Tainhas Rio Grande do Sul. Nic. | |aum. $100 \mathrm{x}$

Foto 8 - Hialo-basalto; Três Forquilras, Rio Grande do Sul. Nic. | |aum. $100 \mathrm{x}$

Foto 9 - Plagioclásio de um xenolito em basalto transformado em rède de "vidro" com núcleos persistentes de plagioclásio; Salto-Canela, Rio Grande do Sul.

Nic. | aum. $100 \mathrm{x}$ 


\section{SUMMARY}

The purpose of the present work was the geological study of the volcanological phenomena related to the effusives (Rhaetic?) of the Paraná basin. Details, mainly from the areas of the states of the Rio Grande do Sul and Santa Catarina are furnished. The results achieved are the followings: 1 ) The age of the volcanic activities is limited between the upper triassic and the upper cretaceous, possibly between the rhaetic and the jurassic.

2) The surface occupied by the continuous effusives has an area of obout one million square kilometers, of which, about a half is covered by younger sediments.

3) The thicknesses were observed in the eastern border of the basin, where the effusives form steep escarpments. The greatest thickness, 1.000 meters, is found near Torres, Rio Grande do Sul. It decreases both to the south and north, and, from this point reaches only a few tens of meters in the farthest points of north and south. The volume of the effusives estimated by this last data is 350.000 cubic kilometers (Fig. 2).

4) The sheet of the effusives is made up of serveral sucessive flows. In more complete profiles, it was possible to verify, eight to thirteen lava flows, separated by a hiatus. This is recognized by intercalations of small banks of sandstones, or lacking the sandstones, by vesicles and vitreous textures together with horizontal diaclases on the top and bottom of each flow. The individual thickness vary from few meters up to 80 meters (Figs. 1, 6, 7)

5) The ground of the flows was practically horizontal dipping only a few meters per kilometer, verified by levelling of precision. A fluidal texture was often seen which is caused by the orientation of the vesicles in the basaltes. The measurements of this texture, in several places, show tow courses of the lava flow (Fig. 13)

6) Explosive activities of the volcanism are seldom observed and are limited to local occurrences in the flow itself.

7) In the countries just near the flows very frequently intrusive bodies of the volcanism namely sill and dike are found. Some of the sills have an area of hundreds of square kilometers and thicknesses around 200 meters (Fig. 14). 
The thicknesses of the dikes vary from few meters to tens of meters. The greatest frequency of dikes is localized in the south of the state of Santa Catarina, where there are 15 dikes in 20 kilometers of distance.

8) The chemical and mineralogical composition of the basaltic magma is uniform and made up mainly of plagioclases (An50-70), augite and pigeonite. However, more acid effusives, of leidleit kind were found, in the top of the flows. The effusive terms are characterized by a basaltic texture rich in vitreous mesostasis, and intrusive terms are detached by ofitic texture.

In the Três Forquilhas-Tainhas profile detailed studies showed the variation and the great content of vitreous material contained in the basaltes (Fig. 16).

The table $n .3$ gives in an abridged manner the chemical analysis of the brazilian effusives performed as yet. Four of them are new Only little variation can be noted in the constitution except in the leidleits. The brazilian basaltic magma is similar with the magmas of other gondwanic flows.

9) The endo and exometamorphic phenomena are insignificant. The preeffusive arenitic basement undergoes only interstitial silicification. Xenolithes are very rare in the basaltes; one of them, a granite, came from at least 1.500 meters deep. It presents only a reaction crown of one centimeter thick. In the reaction zone, the plagioclase partially turns into a "cellular" framework of incolor glass.

10) The basement of the effusives is made up of triassic eolic sandstones of the "Botucatú" formation. The position of the contact between this basement and the effusive is given in the table n. 1. The lowest point in the contact, almost at sea level, is found near Torres, Rio Grande do Sul. It ascends abruptly in the northern direction, to $650-750$ meters, and remains in this level as far as the state of S. Paulo. From Torres to the south the contact ascends gently up to 270 meters in Santa Maria (Fig. 2)

11) Certain number of direct faults was observed in the basement, with throwns as great as 30 meters (Table n. 5) The effusives have evidence of faulting in the form of milonitized zones as well.

Two directions of disturbance is set forth: one, about NNE and the other NW

12) It is probable that there is an important tectonic line between Torres and Posadas, on the ground of the following observations: The glacial sediments (Carboniferous?) show, to the south of this line an intense glacial erosion with little sedimentation and to the north intense sedimentation with marine transgression. In this zone, numerous faultings of the basement preceded the magmatic 
activities. During and after the volcanism, this zone was used as "hinge" of the tectonic movements that have dipped the sedimentary basement in the convergent course of this tectonic belt. The effusives have reached here, its greatest thikness, showing to be one of the zones of magmatic shedding. The submarine ridge called "riograndense" links with this belt (Figs. 13, 17, 21)

13) The formation of morphological escarpments made up of effusives could be originated by the successive magmatic shedding of flows of the same volume and viscosity bounding approximately at the same place. Thus, it has formed a compound pack with rather steep terminations. The erosion has only reworked the original escarpment, making it to retrocede at least 30 kilometers. Thus, numerous outliers, in front of the escarpment was formed.

The steep border of the escarpment near the Atlantic ocean (Rio Grande do Sul) must be originated by relatively modern faultings as is shown by the faultings near Patos lagoon and by the very young fluvial drainage of this escarpment.

14) We have concluded that the magma has ascended in a complete condition of fusion without incipiente crystallization. We have taken Daly's hypothesis to explain the cause of the ascention of the magma. The direct causes, extra and not intramagmatic, are related with the primary opening of deep gaps.

The homogeneity of the magma shows its origin from the sima or rather from the salsima. The opening of geoclases was promoted by strengths of tension and we have linked it with the Wegener's drift movements. As signs of countries of magmatic sheddings we have taken the followings: - Greatest thicknesses of the flows near the focus, and centrifugal thinning - occurrences of sill — faultings and dikes - fluidal textures and dipping of the bottom of the flows.

These indications meet together in the tectonic belt TorresPosadas from where the lava has shedded to the south and to the north in an extension of about 100 kilometers. We believe in the existence of other productive zones. Two belts are localized in the present valley of the Uruguay river and in the eastern border of the escarpment in the state of S. Paulo.

Thus, there is transversal productive zones (Torres-Posadas), longitudinal (Uruguay) and marginal ( $\mathrm{S}$. Paulo), to the axis of the Paraná basin (Fig. 1). 


\section{ZUSAMMENFASSUNG}

Die vorliegende Arbeit befasst sich mit den vulkanologischen Erscheinungen der Basalt- Ergüsse rhaetischen? Alters des ParanáBeckens. Besondere Einzelheiten werden haupsächlich von den Staaten Rio Grande do Sul und Sta. Catharina gegeben. Die wesentlichen Ergebnisse sind folgende:

1. Die vulkanische Tätigkeit liegt zwischen der oberen Trias und oberen Kreide, am wahrscheinlichsten aber zwischen dem Rhaet und Jura.

2. Etwa $1.000 .000 \mathrm{~km}^{2}$ Oberfläche werden auch heute noch von diesen vulkanischen Gesteinen eingenommen, wobei etwa die Hälfte von jüngeren Sedimenten bedeckt ist (Fig. 1).

3. Die Mächtigkeiten der Decken wurden vormehmlich an dem Ostrand des Beckens bestimmt, wo diesse starke Landstufen und Steilabbrüche hervorrufen. Die grösste Mächtigkeit, von etwa 1.000 Metern, erreichen die Deckenergüsse bei Torres im Staate von Rio Grande do Sul. Von hier aus fallen die Mächtigkeiten sowohl nach dem Norden wie nach dem Süden (Fig. 2) Am Nord-wie am Südrand des Beckens finden sich nur einige zehn Meter Mächtigkeiten. Eine Überschlagsrechnung zeigt, dass etwa $350.000 \mathrm{~km}^{3}$ magmatischer Gesteine gefördert wurden.

4. Die Basaltdecke ist aus verschiedenen Einzelergüssen zusammengesetzt. An den vollständigsten Profilen war es möglich. 8 und 13 einzelne Lava-Ergüsse festzustellen, die durch Hiatus getrennt sind (Fig. 5, 6) Dieser ist erkennbar z. $T$ an dünnen, zwischengelagerten Sandsteinbänken. Wo diese fehlen, werden Struktur-Eigentümlichkeiten zur Feststellung benützt. So beobachtet man, dass die Oberfläche eines Ergusses gekennzeichnet ist durch eine blasige Textur und vorherrschend horizontalliegender Klüftung. Die Basis ist dagegen ausgezeichnet durch eine bis mehrere Meter mächtige glasige oder glasreiche Zone, verbunden mit vorherrschender Horizontal-Klüftung (Fig.14) Die Mächtigkeiten der Einzelergüsse schwanken zwischen wenigen Metern und 80 Meter (Fig. 7)

5 Die Ergüsse erfolgten auf praktisch horizontalen Ebenen. $\mathrm{Er}_{\mathrm{r}}$ wurden Neigungswinkel von wenigen Metern pro Kilometer mit Praezissions-Intrumenten gemessen. Sehr häufig beobachtet man eine gut entwickelte Fluidaltextur, die durch Einrichten der Poren hervorgerufen wird. Einmessungen dieser Fliess-Textur zei- 
gen, dass im Staate von Rio Grande do Sul zwei Hauptrichtungen vorkommen (Fig. 13)

6. Anzeichen von explosiver Tätigkeit wurden selten angetroffen. Sie beschränken sich immer auf kleinen Raum und zeigen an, dass sie parasitärische Erscheinungen der Lava-Ergüsse selbst sind. (Fot. 5)

7 In der Nachbarschaft der Ergüsse, aber heute von ihnen freien Gegenden kommen sehr zahlreiche Diabasgänge und Lagergänge vor Einige von diesen erreichen Ausdehnungen von einigen Hunderten $\mathrm{km}^{2}$ bei etwa $200 \mathrm{~m}$. Mächtigkeiten (Fig. 14).

Die Diabasgänge schwanken weitgehend in ihren Mächtigkeiten, (wenig Meter - und verschiedenen zehn Meter). Die grösste Häufigkeit wurde im Südosten des Staates Sta. Catharina beobachtet, wo 15 Diabasgänge in $20 \mathrm{~km}$ angetroffen wurden.

8. Die mineralogische Zusammensetzung der Basaltergüsse ist einheitlich einfach, bestehend hauptsächlich aus Feldspath (50-70\% An) Augit, Pigeonit und glasiger Grundmasse. Nur an wenigen Stellen, an den obersten Teilen der Gesammtdecke, wurden mehr saure Ergussgsteine - Hyalo-Dazit - (Leidleit) angetroffen.

Die Effusivgesteine sind durch ein porfirische Struktur ausgezeichnet, reich an glasiger Grundmasse, während die intrusiven Formen durch ihre ophitische Struktur gekennzeichnet sind.

Am Profil Tres Forquilhas-Tainhas, wurden durch sistematische Dünnschliff - Untersuchungen die Schwankungen des Glasgehaltes der hier 1.000 Meter mächtigen Basalte festgestellt (Fig. 16)

Die Tabelle 3 gibt die bis heute vorgenommenen chem. Analysen wieder - vier davon sind neu. Auch hier beobachtet man leicht die ausserordentlich einheitliche Zusammensetzung des basaltischen Magmas und seine starke Ahnlichkeit mit den anderen gondwanischen Ergüssen.

9. Unbedeutend sind die Veränderungen endo - und exometamorpher Art. Die prae-effusive Unterlage, die aus Sandsteinen besteht, erleidet nur eine unbedeutende Einkieselung. Einschlüsse sind in den Basalten sehr selten. So wurde ein Granitbrocken im Basalt angetroffen, der zumindest aus $1.500 \mathrm{~m}$ Tiefe heraufgetragen wurde. Dieser Einschluss zeigt aber einen Reaktionsrand von nur $1 \mathrm{~cm}$ Mächtigkeit. Hier ist der Feldspath des Granites teilweise in ein Skelett von ungefärbtem Glas umgewandelt worden (Fot. 9)

10. Die Unterlage der Ergüsse besteht fast durchweg aus dem eolischem - "Botucatú" - Sandstein, triassischen Alters. Die verschieden Höhen des Kontaktes - Sandstein-Basalt, finden sich in der Tabelle 1. Der tiefste Punkt - etwa Meereshöhe, liegt bei Torres, Rio Grande do Sul. Von hier aus steigt der Kontakt schnell nach dem Norden hin auf 650-750m an. Von hier aus hält sich der Kontakt über $1.000 \mathrm{Km}$ hin etwa auf dieser Höhe. Auch 
nach dem Süden von Torres aus steigt er an, aber sehr langsam, um bei Sta. Maria sein Maximum von $270 \mathrm{~m} \mathrm{zu}$ erreichen (Fig. 2).

11. Eine gewisse Anzahl von Verwerfungen der Unterlage mit bis zu $30 \mathrm{~m}$ Sprunghöhe wurden angetroffen (Tabelle $n .^{\circ} 5$ ). Auch an den Basaltdecken wurden Anzeichen von Störungen beobachtet, die durch Ruschel - und Mylonitzonen gekennzeichnet sind.

Die Störungen gruppieren sich um zwei Hauptrichtungen, eine streicht NNE die andere NW (Fig. 17, 18)

12. Es wird ein Gross-Störungszone (Torres-Posadas) wahrscheinlich gemacht, deren Annahme sich aus folgenden Beobachtungen ableiten lässt: Die Glazialsedimente (karbonischen? Alters) sind im Süden dieser Zone sehr schwach entwickelt; andererseits zeigt das prae-glaziale Relief hier auf starke Abtragung und hochgelegenen Erosionsraum hin. Das Gegenteil beobachten wir im Norden dieser Zone. Hier zeigen die Glazialsedimente eine starke Mächtigkeit, öfters mit Zwischenschaltungen von marinen Ablagerungen. Das heist aber tiefgelegener Sedimentationsraum. Im Perm - Iratischichten - lagerten sich, sowohl im Süden wie im Norden Meeressedimente der gleichen Fazies ab. Auch während der oberen Trias lagerten sich gleichartige eolische Sedimente sowohl im Süden wie im Norden dieser Zone ab. Erst kurz vor der vulkanischen Tätigkeit wird diese tektonische Zone von zahlreichen Verwerfungen durchsetzt. Während und nach der vulkanischen Phase wirkte diese Linie als tektonisches Gelenk, an dem sich die Sedimentunterlage konvergent nach Süden und Norden neigte. Gerade hier erreichen die Basaltergüsse ihre grösste Mächtigkeit, was wir als eines der Anzeichen auffassen, dass diese $\mathrm{Ge}-$ gend eine der magmatischen Grossförder - Zonen war.

13. Wir nehmen an, dass der morphologisch heraustretende Steilabbruch der Decken sich in Rio Grande do Sul auf folgende Weise bildete: Gleichbleibenden Förderzonen lieferten aufeinander folgende Lava-Ergüsse, die etwa dasselbe Volumen und Viskosität besassen, und daher etwa auf derselben Stelle zum Stehen kamen. So bildete sich ein Paket von Ergüssen mit etwa denselben Endlagen, mit schon ursprünglichen Steilabhängen. Die nachträgliche Abtragung remodelierte diese Abbrüche, und liess sie zumindest $30 \mathrm{~km}$ zurückschreiten.

Anderseits scheint der mächtige Steilabbruch an der atlantischen Küste zwischen Osorio und Torres von fast 1.000 Metern, durch Verwerfung bedingt zu sein. So wurden grosse, etwa NNE streichende Störungen, tertiaren (?) Alters, längs der "Lagôa dos Patos" beobachtet, die vermutlich auch die Basaltdecken erfassten. Auch der ausserordentlich junge Charakter der Flussläufe, mit etwa $1.000 \mathrm{~m}$. Gefälle in wenigen Kilometern, weisst auf die junge Anlage dieses Steilabbruches hin. 
14. Das basaltische Magma stieg zur Oberfläche als einheitlicher Schmelzfluss auf, ohne dass irgendeine Kristallisation schon im Gange gewesen wäre. Als Ursache des magmatischen Aufstieges nehmen wir die Erklärung von Daly, als die wahrscheinlichste an. Die direkten Ursachen des magmatischen Aufstieges, dürften mit dem Aufreissen tiefer Sprünge zusammenhängen.

Das Aufbrechen von "Geo-Klasen" bis zum Sima oder Salsima wird mit der Wegener'schen Verschiebungs-Hypothese in Verbindung gebracht. Folgende Tatsachen nehmen wir als Anzeichen von Förderungszonen des Magmas: a) Grösste Mächtigkeiten der Decken befinden sich in der Nähe dieser Zonen, während die Ergüsse an Mächtigkeit zentrifugal von hier aus abnehmen. b) Häufiges Auftreten von Diabas-Lagergängen. c) Häufiges Auftreten von Verwerfungen des Untergrundes und von Diabasgängen. d) Auswerten der Fluidaltextur und Neigung der Ergussflächen.

Diese 4 Anzeichen finden sich gleichzeitig in der Nähe der tektonischen Grosszone Torres-Posadas. Von hier aus dürfte die Lava sich sowohl nach dem Norden wie nach dem Süden über etwa $100 \mathrm{~km}$ Entfernung ergossen haben (Fig. 1)

Ohne Zweifel kommen aber noch andre produktive Zonen vor Eine etwa N-S Streichende dürfte sich in der Gegend des heutigen Uruguay-Tales befinden. Eine andere liegt vermutlich am Ostrand der Lava-Decken im Staate von São Paulo.

Es sind jetzt 3 Förderungszonen einigermassen bekannt: Die Torres-Posadas - Linie, die das Paraná-Becken transversal durchsetzt; die Uruguaytal-Zone verläuft in der Achse, während die São Paulo-Zone am Rande des Beckens liegt. 
Indústria Gráfica José Magalhães Ltda. - Rua Spartaco, 215 - São Paulo 
